\title{
Coastal Geology of
}

\section{Puerto Rico}

By CLIFFORD A. KAYE

GEOLOGICAL SURVEY PROFESSIONAL PAPER 317

Prepared in cooperation with the Puerto Rico Water Resources Authority, Puerto Rico Economic Development Administration, Puerto Rico Aqueduct and Sewer Authority, and Puerto Rico Department of the Interior

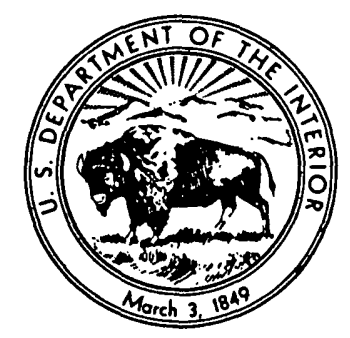


UNITED STATES DEPARTMENT OF THE INTERIOR

FRED A. SEATON, Secretary

GEOLOGIGAL SURVEY

Thomas B. Nolan, Director

The U.S. Geological Survey Library has cataloged thi's publication as follows :

Kaye, Clifford Alan, 1916-

Coastal geology of Puerto Rico. Washington, U.S. Govt. Print. Off., 1959.

iv, 178 p. illus., maps (1 col.) diagrs., tables. $30 \mathrm{~cm}$. (U.S. Geological Survey. Professional paper 317)

Part of illustrative matter folded in pocket.

Prepared in cooperation with the Puerto Rico Water Resources Authority, Puerto Rico Economic Development Administration, Puerto Rico Aqueduct and Sewer Authority, and Puerto Rico Dept. of the Interior.

Includes bibliographies.

(Continued on next card)

G S $59-198$

Kaye, Clifford Alan, 1916- Coastal geology of Puerto Rico. 1959. (Card 2)

CONTENTs.-Geology of the San Juan metropolitan area.-Shoreline features and Quaternary shoreline changes.-Geology of Isla Mona and notes on age of Mona Passage. With a section on The petrography of the phosphorites, by Zalman S. Altschuler.

1. Geology-Puerto Rico. 2. Coasts-Puerto Rico.

I. Title. (Series)

[QE75.P9 no. 317]

G S 59-198 


\section{CONTENTS}

[The letters in parentheses preceding the titles designate separately published chapters]

Page

iii

Preface..

(A) Geology of the San Juan metropolitan area

(B) Shoreline features and Quaternary shoreline changes.

(C) Geology of Isla Mona and notes on age of Mona Passage.

\section{ILLUSTRATIONS}

[Plates 1, 2, and 10-12 are in pocket]

Plate 1. Map of Puerto Rico and neighboring islands.

2. Geologic map of the San Juan area.

3. $A$, View south along Rio Piedras-La Muda highway; $B$, Large contorted shale block in lapilli tuff of the Frailes

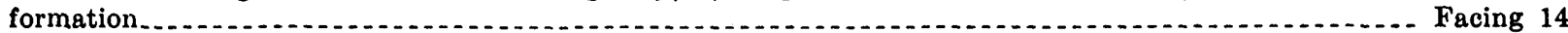

4. $A$, Banded rhyolitic vitrophyre from breccia in the Frailes formation; $B$, Vitrophyre from the Figuera volcanics . . . . . . .

5. $A$, Drumstick dike in thin-bedded ashy siltstone; $B$, Drumstick dike in actinolitic meta-andesite ........... Facing 30

6. $A$, Irregular-shaped replacement of thin-bedded ashy siltstone by andesite porphyry; $B$, Metagraywacke $\ldots . .$. Facing 31

7. $A$, Guaynabo fault scarp; $B$, Small, plunging anticline in ashy siltstone of the Fajardo formation . . ...... Facing 38

8. Gentle folding in ashy siltstone of the Fajardo formation ............ Following 38

9. $A$, Small fault in the graywacke and shale of the Guaynabo formation; $B$, Small normal fault in variegated sands and marls of the Aguada formation. . . . .

10. Chart showing shallow bank off eastern Puerto Rico and La Cordillera reefs.

11. Composite cross sections of some north-coast Quaternary localities.

12. Geologic map of Isla Mona.

13. $A$, Vertical sea cliffs, east coast of Isla Mona; $B$, Cemented red residuum in Lirio limestone ................. Facing 146

14. $A$, Enlarged cavern mouths, Playa Pájaro; $B$, View to southwest from Punta Este, Isla Mona............. Facing 147

Fraure 1. Map of the Greater Antilles

2. Index map of Puerto Rico, showing the San Juan area

3. Stratigraphic nomenclature of the older complex in the San Juan area .

4. Schematic reconstruction of depositional relations of the older complex in the San Juan area....................

5. Major known and inferred faults in the older complex in the San Juan area.

6. Puerto Rican shoreline types....

7. Easterly coastal currents on the north coast $\ldots \ldots \ldots \ldots$

8. Principal oceanic currents of Puerto Rico _.

9. Natural groin, demonstrating northerly drift of sand by longshore currents on the east coast

10. Map showing location of sea-temperature and salinity measurement stations .

11. Northeast trade winds near Punta Manati

12. Wind and swell diagrams from northern Puerto Rico

13. A northwest wave-train at Cayo Icacos

14. Observations of currents in a lunate bay on the north coast

15. Wave pattern, lunate shorelines, and coral reefs at Punta La Bandera

16. Dissected eolianite ridge north of Manati, showing development of lunate shoreline .

17. Dissected eolianite ridge at Punta Puerto Nuevo, showing development of straight shoreline .

18. Coastal geology north of Manat1

19. Lunate resonating basin at Punta Tortuguero

20. Cross section of beach with partly exposed beachrock pavement

21. Very wide beachrock pavement at Punta Puerto Nuevo, showing typical steplike form and curvature with the shore.

22. Slab of beachrock pavement east of Punta Fraile, completely undermined, showing typical wedge-shaped cross section

23. Petrographic section of beachrock at Santa Teresita, San Juan

24. Very much eroded beachrock pavement at San Juan 
25. Collapsing beachrock pavement.

26. Distribution of beachrock, coral reefs, and limestone

27. Distribution of cemented sand dunes

28. Dome, arch, or anticlinal structure in eolianite.

29. Typical intense pitting of eolianite in the spray zone

30. Flat-floored pits in eolianite.

31. Flat-floored pits in eolianite.

32. Development of round-bottomed and flat-floored pits

33. Cylindrical pit.

34. Pitting by the sea urchin Echinometra lacunter on the surface of a tidal terrace.

35. Tidal terrace in eolianite, east of Arecibo

36. Tidal terrace on ocean side of eolianite ridge at low tide

37. Pleistocene roof rock entirely base leveled to tidal terraces

38. Tidal terrace originating as the base level of pitting

39. Development of pit rims into step risers on the tidal terrace surface

40. Nip on lagoonal side of eolianite ridge on north coast

41. Eolianite shore types . .

42. Large block of eolianite, torn from ridge and tossed into position by storm waves

43. Partly destroyed and eviscerated eolianite ridge

44. Oolite from Cayo Icacos

45. Algal conglomerate from west of Ponce.

46. Coral reefs off Central Aguirre, south coast

47. Example of double river outlet, both mouths protected

48. Beach-faceted pebbles

49. Ensenada de Boca Vieja.

50. Eighteenth century maps of the Ensenada de Boca Vieja

51. Coastal geology, Punta Vacía Talega to Punta Miquillo

52. Prograded coast near Punta Cabullon

53. Abandoned beachrock pavement, Boca de Cangrejos .

54. Superimposed beachrock pavements, north shore of San Juan.

55. Map showing relict beachrock pavement, San Juan

56. Maps of San Juan-eighteenth century and photomosaic

57. Large eolianite blocks allegedly placed in 1797 to close mouth of Laguna del Condado

58. Sea-level nip on lagoonal side of eolianite block

59. Castillo del Morro, guarding entrance to harbor

60. Pleistocene section at El Vigfa...

61. Old sea cliffs in Pleistocene deposits, Punta Tortuguero

62. Profile of an $E_{4}$ dune

63. Frequency of soundings of two Puerto Rican banks

64. Chart of Isla Mona and Isla Monito...

65. Diagrammatic sketch of phosphatic limestone.

66. Microscopic relations between calcite and hydroxylapatite in phosphatic limestone.

67. Microscopic relations between martinite and hydroxylapatite in nodular phosphorite

68. Bathymetric map of Mona Passage.

69. Prevailing surface currents of eastern Caribbean for month of August. 


\section{Geology of the San Juan}

Metropolitan Area

\section{Puerto Rico}

By CLIFFORD A. KAỴE

COASTAL GEOLOGY OF PUERTO RICO

GEOLOGICAL SURVEY PROFESIONAL PAPER 317-A

Prepared in cooperation with Puerto Rico

Water Resources Authority, Puerto Rico

Economic Development Administration,

Puerto Rico Aqueduct and Sewer Authority, and Puerto Rico Department of the Interior

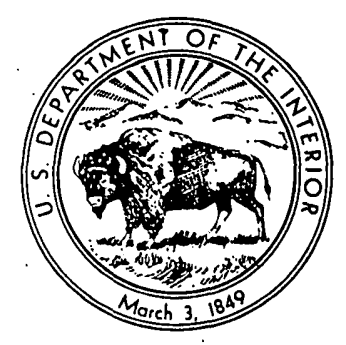


UNITED STATES DEPARTMENT OF THE INTERIOR

\author{
FRED A. SEATON, Secretary
}

GEOLOGICAL SURVEY

Thomas B. Nolan, Director

The U. S. Geological Survey Library has cataloged this publication as follows:

\title{
Kaye, Clifford A 1916-
}

Geology of the San Juan metropolitan area, Puerto Rico. Prepared in cooperation with Puerto Rico Water Resources Authority, Puerto Rico Economic Development Administration, Puerto Rico Aqueduct and Sewer Authority, and Puerto Rico Dept. of the Interior. Washington, U. S. Govt. Print. Off., 1959.

Ix, 48 p. maps (2 fold., 1 col., in pocket) diagrs., tables. $30 \mathrm{~cm}$. (rU. S.] Geological Survey. Professional paper 317-A. Coastal geology of Puerto Rico)

Bibliography : p. 45-46.

1. Geology-Puerto Rico-San Juan area.

metropolitan area, Puerto Rico.

Professional paper

Survey. Coastal geol-

I. Title: San Juan (Series: U. S. Geological Survey. 317-A. Series: U. S. Geological ogv of Puerto Rico)

557.295

For sale by the Superintendent of Documents, U. S. Government Printing Office Washington 25, D. C. 


\section{PREFACE TO "COASTAL GEOLOGY OF PUERTO RICO”}

\section{BACKGROUND}

The varied geologic notes that are the subject of Professional Paper 317 represent field work done from March 1949 through September 1951, when the writer was the U. S. Geological Survey representative assigned to provide geologic advice of an engineering nature to four agencies of the Puerto Rican government, namely: the Puerto Rico Water Resources Authority, the Industrial Development Company (later the Puerto Rico Economic Development Administration), the Puerto Rico Aqueduct and Sewer Authority, and the Insular Department of the Interior. The field studies that make up this report, however, were largely carried on independent of, or incidental to, the specific consulting work that was the first responsibility of the Puerto Rican cooperative project. In 1954 the writer returned to Puerto Rico in order to conduct a field check.

\section{ACKNOWLEDGMENTS}

The cooperation of the Puerto Rico Water Resources Authority, the Puerto Rico Economic Development Administration, the Puerto Rico Aqueduct and Sewer Authority, and the Insular Department of the Interior is hereby gratefully acknowledged. Particularly thanks are due the following officials of the Puerto Rico Water Resources Authority for their continued interest and aid: Antonio Lucchetti, Executive Director (deceased); Carl A. Bock, Chief Engineer; Miguel Quiñones; Manuel Fidalgo; Xavier Cuevas; Pedro Colón; Rafael Reyes; and Alonso Aguilar.

Rafael Fernández García, Director of Industrial Research of the Puerto Rico Economic Development Administration, gave his interest and friendship, provided laboratory facilities, made available mineral-investigation files and reports, and even furnished transportation during the writer's visit to the island in 1954.

The interest and assistance on several occasions of Rafael Picó, Chairman of the Puerto Rico Planning Board, is acknowledged.

Enrique Rubio, Insular Department of the Interior, furnished aerial photographs, maps, and topographic information; and Guillermo Esteves, Puerto Rico Reconstruction Administration (PRRA), allowed the use of the photographic darkroom and the file of aerial photographs that were the property of that agency. Buenaventura Quiñones Chacón and Miguel Meléndez, both of the Puerto Rico Department of Agriculture and Commerce, organized two trips to Isla Mona. Information on the soils of Puerto Rico was given by J. A. Bonnet, Insular Agricultural Experiment Station.

The writer also wishes to thank the University of Puerto Rico and the Insular Agricultural Experiment Station, both at Río Piedras, for granting him full library privileges.

Chemical analyses were made at the writer's request by the Industrial Research Laboratory of the Puerto Rico Economic Development Administration, the fertilizer laboratory of the Puerto Rico Department of Agriculture and Commerce, and the agronomic soils laboratory of the Insular Agricultural Experiment Station.

Historical and archeological information was provided by Adolpho de Hostos; Ricardo Allegría, University of Puerto Rico; Capt. Peter Verhoog; Adam Bishop; Rafael Ramírez, historian of San Juan; E. H. Wadsworth; and Irving Rouse, Yale University. Don U. Deere and J. L. Capaceti provided the writer with valuable subsurface data from their large file of boring records, and L. Antonsanti and Company of Ponce made available their records of water-well logs and well cuttings.

The assistance of the following agencies of the federal government in Puerto Rico is hereby acknowledged:

1. U. S. Coast Guard, for transportation to and from Isla Mona and Isla Caja de Muertos, and for rations and quarters for the writer at the lighthouses while he was visiting both places. The following members of the crew of the Isla Mona lighthouse acted as guides, drivers, cooks, and companions: Justo Gonzales, Nicolas Orlandi, Rafael Figueroa, and Ramón Cruz.

2. U. S. National Park Service, San Juan, for furnishing photocopies of their file of old maps. 
3. U. S. Army Engineers, for logs of foundation borings and beach erosion information.

4. U. S. Army, for maps and photographs of Puerto Rico.

5. U. S. Navy Hydrographic Office, for charts of Caribbean waters.

6. U. S. Coast and Geodetic Survey Magnetic Observatory, Guaynabo, and its chief, Paul Ledig, for seismic data on the Caribbean region.

While it would be difficult to list all those who assisted the writer during his stay in Puerto Rico, it is only fitting to acknowledge a debt of gratitude to the following friends who were of inestimable help in facilitating arrangements, expediting contacts, and finding localities of geologic interest that normally might have been missed: Thomas Haydon, Rosa Haydon, and Heliodoro Blanco.

Of his many colleagues in the U. S. Geological Survey who in one way or another contributed to this study, the writer would like to acknowledge the special interest and help of Wendell P. Woodring, who, besides giving paleontological advice, also visited the project in the field.

Other paleontologists of the U. S. Geological Survey who devoted much of their time to Puerto Rican collections are: Esther Applin, W. Storrs Cole, C. Wythe Cooke, Jean Hough, John B. Reeside, Jr., I. G. Sohn, Ruth Todd, and John W. Wells. Advice on paleontology and taxonomy was also contributed by Alexander Wetmore, Smithsonian Institute; W. J. Clench, Harvard University; Francis Drouet, Chicago Natural History Museum; and H. A. Rehder and R. T. Abbot, U. S. National Museum.

Robert L. Smith, Richard C. Erd, and Fred Hildebrand, U. S. Geological Survey, are to be especially thanked for assistance on petrography and mineralogy, as is Zalman S. Altschuler for contributing the report on the Mona Island phosphorites that is included verbatim in Chapter $\mathrm{C}$ of this study.

\section{SCOPE OF REPORT}

The following pages consist of three separate, nonintegrated papers, all concerned primarily with coastal areas of Puerto Rico or with problems of coastal geology. Each study is published separately as a chapter of Professional Paper 317, and each is largely self-sufficient, thereby serving the specialized reader who may be interested in the subject matter of one chapter but who may not want to thread his way through the entire report.

The first paper (Chapter A) is the presentation of a geologic map of the city of San Juan and its environs. The mapped area, by most continental standards, is small; nevertheless it reveals several highly significant relations within the section of older rocks (older complex, as defined and used in this report), which form the main subject for discussion in this chapter.

Chapters B and C are concerned with geology of a type that is more usually implied by the term "coastal geology."

Chapter B discusses several shoreline forms and processes, including the formation of lunate shores, beachrock, cemented dunes, sea-level nips, tidal terraces, flat- and round-bottomed pits, oolite, and beach-faceted pebbles. The distribution of coral reefs and major shore features is also described. Chapter $B$ also covers the following subjects: The Quaternary marine and eolian stratigraphy of the north coast, criteria for recognizing epeirogenic and eustatic sea levels, the age and stability of the present sea level, and a suggested correlation with the standard glacial section.

Chapter $\mathrm{C}$ is a general report in some detail of the geology of Isla Mona, situated off the west coast of Puerto Rico. The general stratigraphy is described and the geologic history and geomorphic implications of the caverns, sea cliffs, and surface forms are considered. The composition and origin of the cave phosphorites are reviewed in considerable detail. In addition an attempt is made to establish criteria for the age of the strait separating Puerto Rico from the Dominican Republic-Mona Passage.

\section{TOPOGRAPHIC MAPS}

Puerto Rico is entirely covered by modern U. S. Geological Survey topographic maps in four scales: $1: 10,000,1: 30,000,1: 120,000$, and $1: 240,000$. In addition to the geographic coordinates of the polyconic projection, the first two series of maps show the meter grid of the Puerto Rico plane-coordinate system, by which it is possible to relocate a position with accuracy. The last two maps are printed as single sheets.

\section{CONVENTIONS USED IN THE REPORT}

In citing localities, verbal descriptions are sometimes supplemented by notations in the plane-coordinate system, generally given in parentheses after a verbal location $(185,630 \mathrm{~m}, 59,250 \mathrm{~m})$. The first notation-the $x$ coordinate-gives the position in meters east, and the second notation-the $y$ coordinate-gives the position in meters north. This grid system makes it possible to relocate with pre- 
cision. The locations can be plotted accurately by reference to the grid marks on the margins of the large-scale topographic maps. Because both a meterand a yard-grid system have been constructed for Puerto Rico and are ticked on the margins of some maps, the reader must be careful to use the marks of the meter system in plotting locations given in this report.

Measurements and distances are given in inches, feet, miles (either statute or nautical; if the latter, it is so designated), and fathoms. Where specific reference is made to the topographic maps, altitudes are given in meters to conform with the system employed on the maps. The Spanish geographic names used on the topographic maps are generally retained in the text. The numbering of roads is the official designation in late 1955 . This fact may be of some importance, for the highway numbering system has undergone several changes and may do so again.

Verbal descriptions of rock colors in places are supplemented by the Munsell color system notation. The "Rock Color Chart" prepared by a committee of the National Research Council in 1948, was used for these color notations and should be referred to by the reader.

\section{PUERTO RICO: A GENERAL DESCRIPTION}

Puerto Rico was discovered by Christopher Columbus on November 19, 1493, as he sailed westward in the course of his second great voyage to the west. He named the island San Juan de Bautista. Curiously enough, with the passing of time the name of the island and the name of its principal port and capital, Puerto Rico, became reversed to the present usage. The island was governed as a Spanish Crown Colony from its discovery to 1898, when it was ceded to the United States at the conclusion of the Spanish-American War. The island has the status of a commonwealth and is governed in the framework of a constitution written by its own legislature.

Puerto Rico is the easternmost of the Greater Antilles (fig. 1), a chain of large islands which includes, from west to east, Cuba, Jamaica, Hispaniola (consisting of the Republic of Haiti and the Dominican Republic), and Puerto Rico. Immediately east of Puerto Rico are the U. S. Virgin Islands and the British Virgin Islands, a cluster of small islands that, although geologically related to the Greater Antilles, geographically are the northernmost of the Lesser Antilles. The latter constitute an archipelago of small islands that stretch southward in a

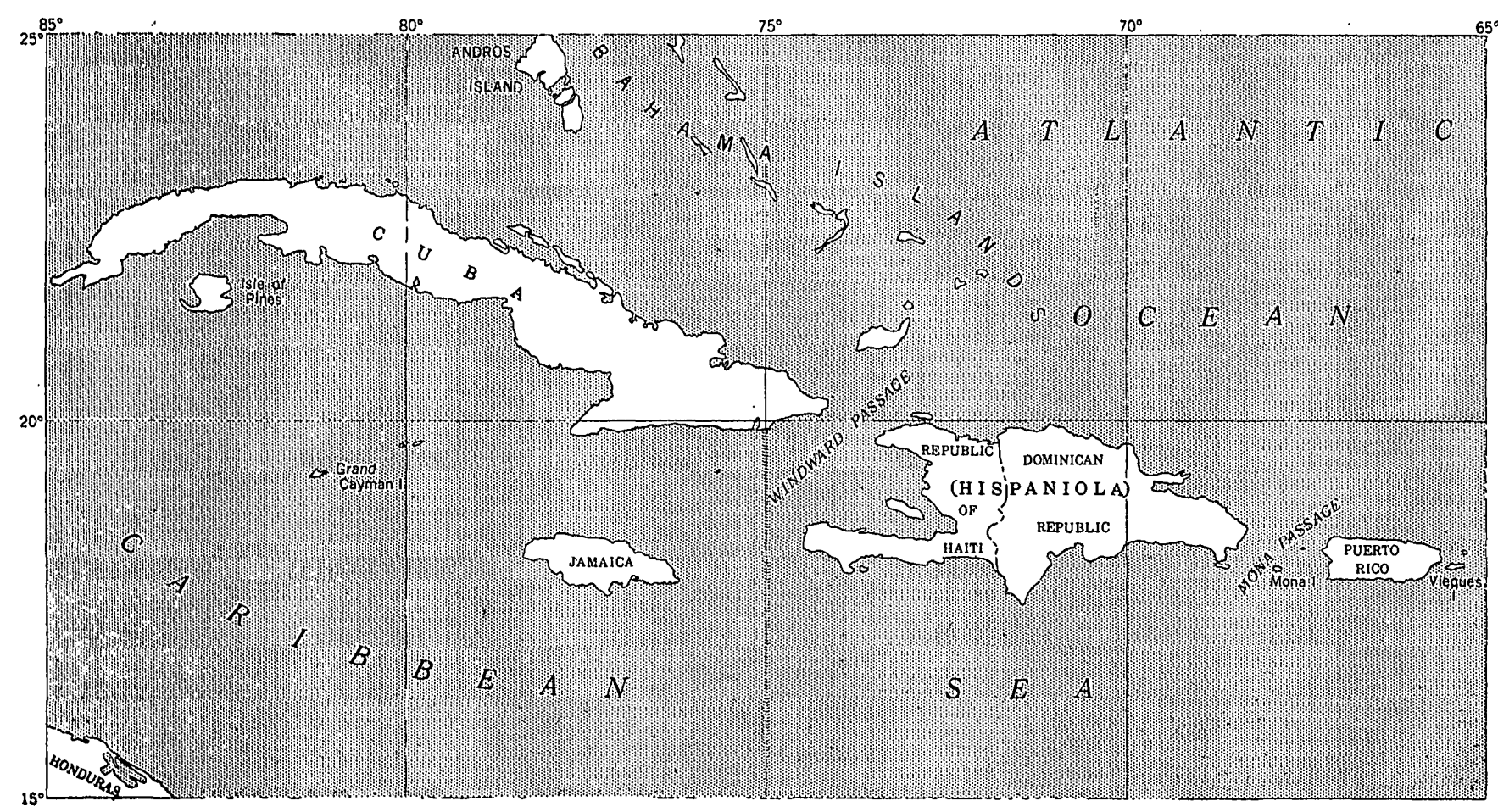

Fiadre 1.-Map of the Greater Antilles. 
broad arc from the Virgin Islands to eastern Venezuela. The Greater and Lesser Antilles enclose the Caribbean Sea; waters outside this great island arc are referred to as the Atlantic Ocean.

Puerto Rico is roughly rectangular in shape (pl. 1) with its long dimension, or axis, oriented from east to west. It measures approximately 110 miles from east to west and 37 miles from north to south; its area is 3,421 square miles. Several small outlying islands are politically part of Puerto Rico. The largest of these are Isla de Vieques and Isla de Culebra off the east coast, Isla Caja de Muertos off the south coast, and Isla Mona and Isla Desecheo off the west coast.

The topography of Puerto Rico is extremely varied, but most of the island is hilly to mountainous, with the maximum relief generally in the interior. Very steep slopes and narrow valleys characterize most of the interior, though here and there one finds local widenings of the valleys and even broad interior basins, such as that at Cayey. The divide separating the Atlantic from the Caribbean drainage lies somewhat south of the geographic axis of the island, and in consequence the general orographic slope is steeper on the south side of the island.

The highest point on Puerto Rico is that of Cerro de Punta (altitude, 1,338 $\mathrm{m}$ or 4,390 feet), which is located on this divide. In addition to the high peaks along the principal insular divide, an isolated and very prominent cluster of peaks that attains a maximum altitude of $1,074 \mathrm{~m}(3,532$ feet $)$, the Sierra de Luquillo, occurs at the northeast corner of Puerto Rico.

A broad east-west belt of exceptionally rugged karst topography characterizes much of the north side of the island. Here one finds vertical to steeply conical knobs of Tertiary limestone rising abruptly from flat alluvium-covered plains or, where the weathering of the limestone is less advanced, from a plexus of deep sinkholes. When viewed from afar, the surface of this karst topography-with its wave on wave of sharp-crested limestone hills-strongly resembles a choppy sea. Except for the major rivers cutting across it, drainage in this limestone belt is underground.

Part of the north coastal area is low and swampy, indented, here and there, by small bays and lagoons and the well-protected harbor of San Juan. The east and west coasts of the island consist of alternating low alluvial plains and hilly headlands. The south coast of the island-except for the western part, which consists of low limestone hills, and for several miles near the eastern end, which is mountainousis a low alluvial plain that fringes the foot of the steep-sloped upland.

Broadly viewed, the major geologic units of Puerto Rico are arranged in a simple pattern. Structurally, the island is a geanticline, or broad arch, whose axis is essentially the same as the geographical axis. Younger rocks crop out on both north and south coasts, where they dip gently north and south, respectively, away from the outcrop of the older rocks, which extends as a continuous belt from the west to the east coast and forms the more rugged interior of the island.

The older rocks, which are grouped together in this report under the term "older complex," consist of an unknown thickness of sedimentary and volcanic rocks of Late Cretaceous to Paleocene or early Eocene age. These rocks have been intruded by ultrabasic to acid magmas in bodies that range in size and shape from small sills and dikes to batholiths. The large area of plutonic rock in the southeastern part of the island is batholithic in size, but that in the central part of the island, around Utuado, is perhaps more suitably termed a large stock. This entire sequence of the older complex rocks is lithologically quite similar to rocks of the same age in the other islands of the Greater Antilles.

The older complex is much deformed by faulting and, to a lesser extent, by folding. Most fold axes are alined to the northwest. The principal exceptions to this are on the peripheries of the larger intrusions, where the strike of the beds tends to conform to the general outline of these bodies, and in the northeast and southwest corners of the island, where the strikes are more nearly east-west (chapter A).

On the north and south side of the island are limestones, marls, and some noncarbonate sediments of late Oligocene to early Miocene age. These overlie the older complex unconformably and dip at a prevailingly moderate inclination away from the axis of the island. These beds are locally folded (particularly on the south coast) and faulted but in general, when compared to the older complex, seem relatively undisturbed (Kaye, 1957).

The outcrop belt of middle Tertiary rocks on the north side of the island has a maximum width of 13 miles, measured across the strike. This belt extends for nearly the entire length of the coast. The corresponding outcrop belt of middle Tertiary rocks on the south coast is smaller, both in width and length. 
Besides the older complex basement of the island and the middle Tertiary sedimentary blanket flanking it on the north and south coasts, the only other noteworthy rocks are marine and eolian deposits of Pleistocene age, which are mostly on the north coast and on some of the outlying islands, and alluvial deposits along the coasts and in the structural and erosional basins of the island's interior.

The climate of Puerto Rico is subtropical marine and is largely controlled by the northeast trade winds. Precipitation varies from high on the windward (north) side of the main insular divide to relatively low on the lee (south) side of the divide. The recorded extremes are the high peaks of the Sierra de Luquillo in the northeast corner of the island, which have an average annual precipitation of 196.63 inches at the La Mina station, and at Lajas, in the southwestern corner of the island, with an average annual precipitation of 28.82 inches. The temperature range is small and temperatures below $70^{\circ} \mathrm{F}$. or above $90^{\circ} \mathrm{F}$. are relatively rare. Seasons are poorly defined, both as to temperature and rainfall. Showers of short duration due to very local atmospheric convections occur during daylight hours throughout the year. Puerto Rico lies within the North Atlantic hurricane track but at the time of writing (1956) has been stricken directly only three times during the present century. However, near misses by hurricanes have been more numerous and these are generally accompanied by severe rains and floods.

The island is crisscrossed with roads. Indeed, from the point of view of both density and quality the road net is probably second to none in a terrain and climate of this type. Most of the island is readily accessible to the geologist by road or trail; there are only a few areas more than moderately difficult of access, and of these the badly dissected karst country northeast of Lares is probably the worst. The great density of population (628.13 per square mile) has necessitated the cultivation of almost all but the very poorest land, and in consequence habitations dot the highest hills. 



\section{CONTENTS}

Preface to "Coastal Geology of Puerto Rico"

Abstract..... Introduction . .

Location and geographic setting

Previous work

Physical features.

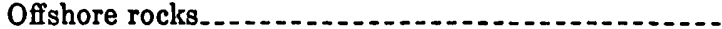

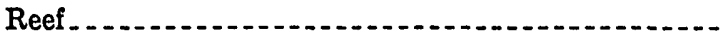

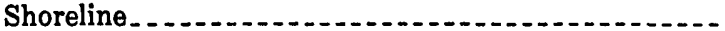

Isla San Juan . . . .

Santurce.

Bahla de San Juan and lagoons.....................

Coastal plain

Prominent hills in coastal plain and mangrove swamps.

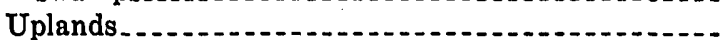

Valley of the Rio Grande de Lolza .................

General geology ...

Older complex...........

Hato Puerco tuff

Guaynabo formation . . . . .

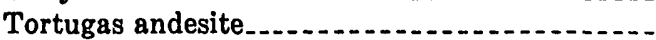

Frailes formation, including $\mathrm{La}$ Muda and

Leprocomio limestone members.

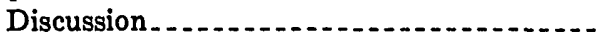

La Muda limestone member.

Leprocomio limestone member..........

Age and correlation.

Monacillo formation.

Trujillo Alto limestone

Figuer volcanics

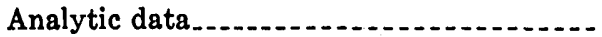

Age and correlation

Discussion.
General geology-Continued

Older complex-Continued

Fajardo formation

Intrusive igneous rocks. ..................... 29

Albitized biotite granodiorite porphyry .... $\quad 29$

Augite andesite porphyry ............. 30

Diabase . . . . 30

Age of intrusive rocks. .................. 31

Metamorphism and albitization......... 31

Regional metamorphism

Albitization . .

Assimilation, metasomatism, and contact metamorphism

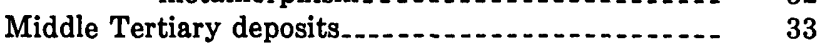

Aguada formation . . . . . 33

Aymamon limestone .................. 34

Late Tertiary and Quaternary deposits _........... 35

Older alluvium

Pleistocene littoral deposits. . . . . . . . . .

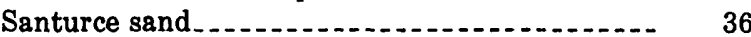

Recent littoral deposits...................... $\quad 37$

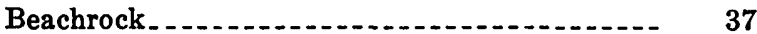

Bay mud_:

Recent alluvium

Structure.

Summary of main geologic events............... 40

Engineering geology ....... 43

Foundation.

Borrow and quarrying

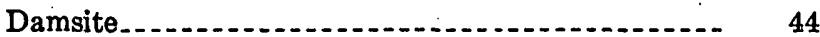

Rock slides........ 45

References cited

Index....

\section{ILLUSTRATIONS}

[Plates 1-2 are in pocket]

Plate 1. Map of Puerto Rico and neighboring islands.

2. Geologic map of the San Juan area, Puerto Rico.

3. A, View south along Rio Piedras-La Muda highway; $B$, Large contorted shale block in lapilli tuff of the Frailes formation.....

4. $A$, Banded rhyolitic vitrophyre from breccia in the Frailes formation; $B$, Vitrophyre from the Figuera volcanics

5. $A$. Drumstick dike in thin-bedded ashy siltstone; $B$, Drumstick dike in actinolitic meta-andesite Facing--

6. $A$, Irregular-shaped replacement of thin-bedded ashy siltstone by andesite porphyry; $B$, Metagraywacke, Fajardo quadrangle, north side of Rí Demajagua valley _. .

7. $A$, Guaynabo fault scarp, about two miles southeast of Guaynabo; $B$, Small plunging anticline in ashy siltstone of the Fajardo formation, near Guaynabo filtration plant.

8. Gentle folding in ashy siltstone of the Fajardo formation.....

9. $A$, Small fault in graywacke and shale of the Guaynabo formation; $B$, Small normal fault in variegated sands and marls of the Aguada formation.

FIgURE 1. Map of the Greater Antilles .

2. Index map of Puerto Rico showing the San Juan area

3. Stratigraphic nomenclature of the older complex in the San Juan area

4. Schematic reconstruction of depositional relations of the older complex in the San Juan area.

5. Major known and inferred faults in the older complex in the San Juan area 
THE COASTAL GEOLOGY OF PUERTO RICO

\title{
GEOLOGY OF THE SAN JUAN METROPOLITAN AREA
}

\author{
By ClIFFord A. KAYE
}

\begin{abstract}
The San Juan area comprises about 80 square miles centered about the city of San Juan and includes the San Juan and the northern half of the Aguas Buenas topographic quadrangles. The area consists of a very gently sloping coastal plain in the northern part and a low to moderate hilly section on the south. The coast is marked mostly by sand beaches, but at the western end of the area eolianite crops out in the sea cliffs of San Juan and the adjoining low hills as well as in the chain of small rocks that rise offshore. Behind the coast occur several enclosed to nearly enclosed lagoons, including the admirably protected harbor of Bahia de San Juan. In the southern part of the coastal plain several hills and steep-sided rocky ridges of Miocene limestone rise abruptly from the featureless plain. To the south the uplands, which are underlain by rocks of Late Cretaceous to late Paleocene or early Eocene age, rise progressively and develop a rugged aspect only at the southern edge of the map area. The only sizeable river is the Rio Grande de Loiza, the largest on the island, with almost 225 square miles of watershed. Its known rate of discharge varies from a minimum of 48 cubic feet per second to a maximum of 125,000 cubic feet per second. The river flows on rock and thin alluvial sand and gravel and has a valley over 650 feet deep in the southwestern corner of the area.

The uplands are underlain by a sequence of much-deformed rocks, the older complex, ranging in known age from Late Cretaceous to late Paleocene or early Eocene. It consists of volcanic, tuffaceous, and sedimentary rocks, of both marine and nonmarine facies, and shallow to hypabyssal intrusive. rocks. The stratigraphic sequence, from oldest to youngest, is as follows: Hato Puerco tuff-prevailingly massive volcanics with some stratified ash. They show a somewhat higher grade of regional metamorphism than the younger rocks. Guaynabo formation-graywacke, conglomerate, and shale, which are probably nonmarine in origin. Tortugas andesite-augite andesite breccias and flows of local prominence. Frailes formation-a marine accumulation of shale, siltstone, and graywacke, with lenticular limestone in the lower part (La Muda limestone member), massive lapilli tuff in the middle, and well-bedded tuffaceous limestones (Leprocomio limestone member) in the upper part. Monacillo formation-predominantly graywacke and conglomerate, commonly red to purple in color and possibly nonmarine. Trujillo Alto limestone-medium-bedded to massive fossiliferous pure limestone. This formation probably marks the top of the Cretaceous section. Figuera volcanics-hornblende andesite breccia with minor flows. Tuff aceous limesțone and
\end{abstract}

derived limestone blocks occur in base. Fajardo formationthin-bedded ashy siltstone and chert that grades laterally into coarse clastics.

Late Cretaceous marine fossils have been collected from the Frailes formation and the Trujillo Alto limestone. Although diagnostic fossils have not been found above the Trujillo Alto limestone, it is proposed that the Figuera volcanics correlate with the late Paleocene or early Eocene deposits of Loíza, to the east, and Corozal, to the west. It is estimated that the older complex in the San Juan area aggregates 16,000 feet or more in thickness.

Three types of intrusive rock are recognized in the older complex of the San Juan area. Biotite granodiorite porphyry, now albitized, crops out in the southern part of the area and seems to be the top of a large subjacent mass. Augite andesite porphyry occurs in tabular and irregular-shaped masses. This rock shows evidence of a certain amount of wallrock assimilation. Diabase dikes, sills, and pipes also occur fairly widely. From cross-cutting relations all three rock types are thought to be early Tertiary in age and to postdate the entire stratigraphic section.

Although megascopically none of the rocks of the San Juan area are metamorphic in aspect, all of them show secondary mineralogic changes indicative of low-grade regional metamorphism. This is more pronounced in some rocks than in others. Plagioclases, more often than not, have been partly or entirely altered to albite; and chlorite, epidote, clinozoisite, and calcite are common. Very fine grained amphibolites also occur. There is some basis for thinking, however, that the rocks have responded more to the introduction of new constituents and to heat than to pressure. The assimilation of wallrock by andesitic intrusion is indicated in many places by relict wallrock structures, textures, fragments, and the bulbous termination to andesitic dikes without the structural distortion of the surrounding wallrock (such as would result from dilation).

The middle Tertiary is separated from the older complex by an angular unconformity. Two formations, both probably early Miocene in age, are recognized in the San Juan area: the Aguada formation and the Aymamón limestone. The former consists principally of compact sand, silt, marl, and lenticular arenaceous limestone and is approximately 325 feet thick. The latter is medium- to thick-bedded, dense white to pink limestone with some interbedded marl and sand. The outcrops of the Aymamón limestone project through the coastal plain alluvium in steep-sided rocky hills. From surface evidence it is computed that roughly 950 feet of Aymamón limestone underlies San Juan, on the north 
coast. Data from seismic work using reflection methods, however, indicate the occurrence of close to 3,000 feet of middle Tertiary sedimentary rocks and suggest a probable thickening of the middle Tertiary section to the north.

Older alluvium, consisting of thoroughly decomposed sands and gravels, blankets part of the upland and higher stream terraces and much of the coastal plain. Light gray and buff reticulations are rather characteristic and seem to be due to leaching by acidic subsurface water along fractures and roots. Littoral deposits of Pleistocene age, consisting of cemented dune sand (eolianite) with some interbedded shallow marine and beach deposits, crop out on Isla San Juan, Santurce, and the offshore islets. The Santurce sand is a medium-grained, well-sorted quartz sand and clayey sand that is particularly thick in Santurce and is widespread on the north coastal area of the island. The sand is probably mostly older alluvium that has been reworked by sheet erosion and then by wind. Much of the quartz was probably originally derived from the middle Tertiary limestones. The white coloration (lack of iron staining) that is rather characteristic of the deposit may again be due to leaching by acidic ground waters. Littoral deposits of Recent age consist of beach sands and associated dunes and sand aprons. The sand is generally medium to coarse grained and is made up of both mineral grains and shell fragments, in variable proportion. Bay mud, or muck, is the soft, highly organic clay that fringes San Juan Bay. It is 25 to 35 feet thick over most of this area. Alluvium of Recent age, consisting of gray to red clays, sands, and gravels occur on the poorly drained meadows flanking the bay and in the beds of the larger streams and rivers.

The rocks of the older complex are much deformed. In the San Juan area they have been folded into several large, fairly symmetrical flexures, which strike east for most of their length, and whose sides dip at moderate angles. Highand low-angle faults abound. A large thrust, which seems to vary along its strike from high to low angle and which dips north, crosses the entire area. Horizontal displacement along this fault is estimated to exceed 3 miles. The larger high-angle faults in the area form a conjugate pattern of two dominant trends: west-northwest and east-northeast. Some of these faults preceded the displacement of the large thrust and also the intrusion of the granodiorite porphyry. Others show later movement and a few were probably active in the late Tertiary or early Quaternary. Several eroded scarps may have been produced by this late movement. The middle Tertiary strata dip north at angles as large as $6^{\circ}$. Steplike structural undulations and possibly folds with very small closure occur. The middle Tertiary is broken by relatively few faults, which are mostly high-angle normal faults of small displacement.

At least the lower part of the older complex of the San Juan area probably represents accumulations on the flanks of a large volcanic cone. The Hato Puerco tuff is thought to have formed part of this cone. Higher stratigraphic units are either alluvial deposits on the flanks of the cone or their marine continuations. Interstratified volcanic rocks may have been derived from smaller local vents. The cone rested on a foundering crust, and so in time it was probably entirely overlapped by marine deposits. No evidence of an abyssal depositional environment for any of the rocks in the area has been recognized. The orogeny that deformed the older complex took place in the late Paleocene or the Eocene (probably the latter). The absence of signs of a dominant direction of tangential stress suggests deformation by sliding into a troughlike downwarp. The dominant northwest alinement of fold axes in the island points to a northwest orientation for this trough. The larger intrusive masses may have formed as a result of fusion of the roots of the downwarp followed by forceful injection of the magma into higher levels with continued foundering. The subsequent uplift of the downwarped rocks may have been chiefly an isostatic response to deeply infolded light crustal material. The coarse-grained alluvium of the basal middle Tertiary deposits show that Puerto Rico was characterized by a rugged topography in late Oligocene time. Downwarping on both the north and south of an east-west axis occurred at this time, and this broad geanticlinal structure has dominated the structural deformation of the island ever since. This east-west structural axis may be genetically related to the essentially east-west alinement of the Puerto Rican trough, the foredeep that lies north of the island. The island was apparently reduced to an old-age erosion surface by late Miocene or early Pliocene time. In late Pliocene or early Pleistocene time it was again re-arched along its east-west axis but mostly by the movement of fault blocks. Two such eroded scarps from this faulting occur in the San Juan area.

The engineering characteristics of the geologic materials of the area are briefly summarized. The older complex rocks are almost everywhere covered by a silty clay regolith of residual and alluvial origin. For most of the formational units, the physical properties of this clayey blanket seem to be much alike. Exceptions to this are the pure limestones, which are covered by clays of fairly high plasticity, and the graywackes of the Guaynabo formation, which yield a sandy regolith. Most of the heavy structures in the San Juan area are built on older alluvium, Santurce sand, the bay mud, and Recent alluvium. The Santurce sand has varied though generally low strength for footings. Construction on bay muds generally requires piles to the underlying older alluvium; undue settlement of roads has been eliminated in one instance by the use of vertical sand drains. The older alluvium is generally quite compact and has moderate bearing strength. Formations most used for crushed rock, building stone, and general fill are the Hato Puerco tuff, Tortugas andesite, the La Munda and Leprocomio limestone members of the Frailes formation, the Trujillo Alto limestone, the ashy siltstone of the Fajardo formation, and the Aymamon limestone. The Recent alluvium of the Río Grande de Loiza is the largest source of gravel for concrete aggregate. The site of the dam across this river is briefly described. The rock is a very fine grained amphibolite, a metavolcanic component of the Hato Puerco(?) tuff, hornblende diorite, and aplite. The rock was sound, massive, and unusually fresh close to the surface, so that very little stripping was required. The dam had a minimum of foundation problems.

\section{INTRODUCTION}

The geologist working in the older deformed rocks of Puerto Rico sooner or later comes to realize that the structural and stratigraphic complexities are too great to permit a satisfactory synthesis of the island's geologic history on the basis of reconnais- 
sance, or small-scale, mapping. Stratigraphic ambiguities in particular seem at first an insurmountable barrier to a proper understanding of past events; in consequence, the need for detailed largescale mapping becomes strongly manifest. It was with the purpose therefore of making such a map that the area about the capital city of San Juan was studied at irregular intervals during the period 1949-51.

The San Juan area is particularly well chosen for such a study. Although the area is small, it encompasses nearly the full range of geology known on Puerto Rico; and, owing mostly to man's engineering activities, it provides an exceptional wealth of rock exposures for a region generally characterized by thick soils and few outcrops. The many road cuts, quarries, and excavations for buildings and small houses provide the geologist with advantages not found in such profusion elsewhere in Puerto Rico.

Field mapping was done on the published topographic map (scale $1: 10,000$ ) and on aerial photographs (scale about $1: 18,000$ ). Geologic mapping was completed for the San Juan $7^{\circ} 30^{\prime}$ quadrangle, which includes all the San Juan metropolitan area, and the northwest and a part of the northeast quarters of the Aguas Buenas $7^{\circ} 30^{\prime}$ quadrangle, which adjoins on the south. The San Juan quadrangle and the northern half of Aguas Buenas quadrangle have been combined and printed as one sheet (scale $1: 30,000$ ) in this report for presentation of the geologic map (pl. 2).

\section{LOCATION AND GEOGRAPHIC SETTING}

The San Juan area includes the capital city of San Juan and its environs and encompasses a land area of about 80 square miles. The city of San Juan is located on the eastern part of the north coast of Puerto Rico, and the mapped area (pl. 2) is bounded by the geographic coordinates: latitude $18^{\circ} 18^{\prime} 45^{\prime \prime} \mathrm{N}$. to latitude $18^{\circ} 30^{\prime} \mathrm{N}$.; longitude $66^{\circ} 00^{\prime}$ $\mathrm{W}$. to longitude $66^{\circ} 7^{\prime} 30^{\prime \prime} \mathrm{W}$.

The northern part of the area is a very gently sloping coastal plain indented by several large lagoons and the semienclosed embayment of Bahía de San Juan. South of Río Piedras the land is hilly, becoming progressively more so as one penetrates deeper into the island interior.

The entire area is densely populated in both the urban and the rural sections, attaining a maximum concentration on the coastal plain in the city of San Juan (a political unification of now coalesced but formerly separate communities of San Juan,
Santurce, Hato Rey, and Río Piedras). Surrounding the city itself are numerous suburbs, settlements, roadside communities; and hamlets that are all economic appendages to the city.

At the time the study was made, a building boom, unprecedented for the island, was spreading the edges of the urban area at a rapid rate, and in consequence the culture shown on the topographic base map of plate 2 is obsolete. The city has grown from its original site on the narrow island on the north side of the bay to encompass not only much of the better drained alluvial ground of the coastal plain but also to infringe on the extensive salt marshes surrounding the bay and the adjoining lagoons.

Where slopes are not too steep the rural areas are mainly given over to sugarcane cultivation. Steep slopes are used mostly for tobacco, small root crops, fruits, and minor coffee cultivation. Most of the original forest cover has been stripped, and such trees as one sees are generally flowering ornamental trees, the many tropical fruit-bearing species, and the shade trees of coffee plantations. The poorly drained alluvial land of the coastal plain is used almost exclusively for dairying.

\section{PREVIOUS WORK}

The area covered by this study lies within areas designated as the San Juan and the Fajardo districts in the "Scientific Survey of Porto Rico and the Virgin Islands," by the New York Academy of Science, a scientific survey of broad scope initiated in the early part of the twentieth century (fig. 2). Maps of both these districts were published in separate geologic reports (Semmes, 1919; Meyerhoff and Smith, 1931) of this early survey. The geologic map (scale $1: 62,500$ ) accompanying Semmes' report on the San Juan district includes a strip along the west margin of the present study, and Meyerhoff and Smith's map (scale 1 inch to 1 mile) includes the entire area of the present study.

A. K: Lobeck (1922) included the San Juan area in his study of the physiography of Puerto Rico, as did C. P. Berkey (1915) in his reconnaissance of Puerto Rican geology. Several of the formational names used by Meyerhoff and Smith and in this report were first proposed by Berkey.

It would be well at the outset to recall some of the conditions under which these earlier geologic studies were made in order to explain the basis for certain differences between the maps of Semmes (1919) and Meyerhoff and Smith (1931) and that 


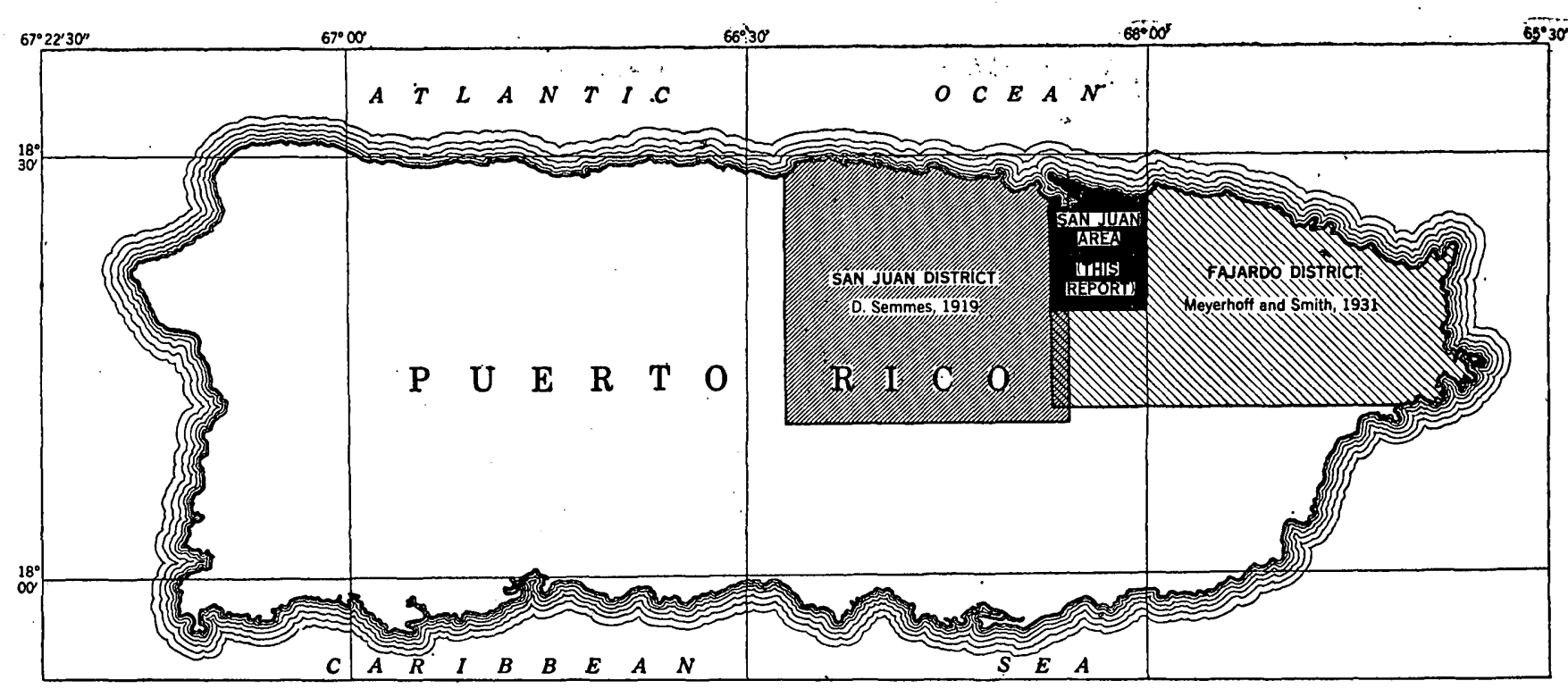

Frgure 2,-Index map of Puerto Rico, showing the San Juan area of this report, and the San Juan and Fajardo districts of earlier authors.

which accompanies this report (pl. 2). The areas involved in both the San Juan and Fajardo districts of the New York Academy of Science reports were large, about 500 square miles each. The field work for both reports was of a reconnaissance nature and was done during the course of one or two summer seasons. The several authors were obliged to make their own base maps in addition to doing the geology of these broad tracts. Roads were fewer than they were in 1951 and many man-made exposures provided by the modern road net were not yet in existence. In the light of these handicaps, the quality of both reports is outstanding and differences between the earlier and the present map become understandable.

\section{PHYSICAL FEATURES}

The San Juan area lies on the north of Puerto Rico and includes parts of the low-lying coastal plain on the north and of the hilly uplands of the Puerto Rican interior on the south. Several topographic features, including the coastal plain and the uplands, merit separate descriptions. The shore is mostly low lying, with sandy beaches and, here and there, small rocky headlands. Off the coast there are small rocks and rock reefs, which are for the most part cemented sand dunes now partly or entirely inundated. Other cemented dunes form the hill of Santurce and the narrow island of the old city of San Juan. Behind the coastal strip with its belt of cemented dunes are two large lagoons, fringed by tracts of mangrove swamp; one of the lagoons, Bahía de San Juan, has a broad, deep-water mouth.
Rising gently southward from the lagoons is a coastal plain made up of alluvial sediments, through which, at several places, project ridges and bosses of Miocene rock. The coastal plain terminates to the south against hills of the uplands, which tend to increase in altitude southward as one approches the interior of the island. The largest river in the area is the Río Grande de Loíza, which empties into the Atlantic Ocean east of the San Juan area.

\section{OFFSHORE ROCKS}

At several places off the north coast there are small rocky islets, notably: Isla Verde, off Punta el Medio; Isla Piedra, about a mile off Punta Las Marías; and three groups, including the large Peñon de San Jorge off the island of San Juan. The latter rocks exhibit very well the east-west alinement that is common to these features along much of the north coast of Puerto Rico. The rocks are small, generally considerably less than an acre in area, and consist of eolianite (cemented dune sand). Except for Isla Verde, which supports a lone coconut palm growing from a thin sandy cover, the islets are without soil. The rocks-again except for Isla Verde, which apparently is a fragment of a former shore isolated by beach erosion-are the tops of sand dunes, now cemented into a friable sandstone and partly inundated by the sea (see chapter B, "Shoreline Features and Quarternary Shoreline Changes"). They vary in form, some possessing a humped profile, relict of the original dune shape, whereas others, which have been reduced by pitting and wave erosion, are simply flat platforms at high- 
tide level. These offshore rocks receive the full force of the Atlantic waves and even the highest of them, the Peñon de San Jorge, is more often than not completely bathed with spray.

\section{REEF}

A narrow belt of shoal water and reef extends westward, from the east edge of the map, through the offshore rocks. Although in places the reef is marked by growths of true reef organisms, the feature is interpreted as being primarily a line of submerged cemented sand dunes. The shallow bench formed by these submerged sand dunes form both a rocky barrier (a rock reef) and a platform on which reef corals are able to thrive.

\section{SHORELINE}

Except for the island of the old city of San Juan, the shoreline is low. Broad sandy beaches extend nearly the entire length of the shore east of Punta Piedrita. The beaches, with the exception of the lunate beach between Punta Las Marías and Punta El Medio, are characterized by an intermittent pavement of cemented beach sand, or beach rock, at intertidal levels. Behind most of the beaches are low sand ridges that generally rise no higher than 10 feet above sea level. Low ridges of eolianite crop out at several places on the shoreline between Punta Piedrita and the mouth of the Laguna del Condado.

Although the coast is ordinarily somewhat protected by the reef, large waves are able to carry much of their energy to the shore, and in recent decades beach erosion has been particularly severe between Punta Las Marías and Punta El Medio (U. S. Beach Erosion Board, 1948). Moreover, the width of the sand beaches is delicately adjusted to the size and character of the surf. During intervals of large waves, beaches not infrequently recede 100 or more feet in a few days, only to advance the same distance during the ensuing intervals of normal surf.

ISLA SAN JUAN

The old city of San Juan (or Puerto Rico, as it was first called) was established in 1521 on the elongated island forming the north side of Bahía de San Juan. The island is tied to the mainland by two short bridges and a causeway, in consequence of which some of its insular characteristics have been lost and local residents are inclined to think of it as a peninsula. The island extends to the west edge of the San Juan quadrangle. West of this is the narrow harbor mouth that connects the bay with the ocean.
Except at its eastern end, the ocean side of the island is a steep cliff that ranges from 30 feet to about 100 feet in height. From about the midpoint of the island, or at the old fortress of San Cristóbal, and continuing westward to the El Morro fortification at the harbor mouth, the cliff is cut mainly in eolianite and is encumbered by houses and colonial fortifications down to the water's edge. East of the San Cristóbal battlements, the cliff face is mostly very friable eolianite and uncemented sand, and the slope is not marred by manmade structures.

The highest point on the island lies in the western part and is shown on the topographic map as enclosed by the 35-meter contour line. The ridge drops off steeply to the south and is partly terminated by a high retaining wall built during colonial times.

The narrow port and warehousing area along the southern edge of the island is mostly reclaimed marshland.

\section{SANTURCE}

Physiographically, the broad low hill on which much of Santurce is built is a continuation of the eolianite ridge that forms Isla San Juan. In Santurce the ridge is about $2 \frac{1}{2}$ miles long and about three-fourths mile wide and trends west-northwest. The highest point is encircled by the 35-meter contour line. In places near the crest hard eolianite crops out, although for the most part the ridge is blanketed by loose sand and clayey sand. Because the entire area is heavily built up, the topographic form is somewhat obscured and altered by construction.

\section{BAHfA DE SAN JUAN AND LAGOONS}

In the San Juan quadrangle a nearly continuous belt of salt marshes and lagoons separates the narrow coastal plain and the shoreline proper. The Laguna San José and its appendage, Laguna Los Corozos, have no direct outlet to the ocean; both are blocked at their seaward end by low beach ridges. They connect, however, with Bahía de San Juan (or, as it is called in this report, simply the bay) by means of the narrow overflow channel of Martín Peña. Circulation of water in the Laguna San José is sluggish, and there is little discharge when the water level of the bay is high for an extended period. The stagnation resulting from this impeded circulation has resulted in a considerable nuisance to the adjoining parts of the city, which are periodically bothered by strong miasmas.

The bay is fringed by a mangrove swamp, which is being rapidly reclaimed as the industrial hinterland of the city spreads. The low-lying peninsula 
on the northeast side of the bay, which is occupied by the U. S. Naval Reservation and the Isla Grande International Airport, is mostly made-land and reclaimed marshland.

The bay itself has a central dredged channel leading to the harbor mouth west of San Juan, which, according to U. S. Coast and Geodetic Survey Chart 908. (San Juan Harbor), attains a maximum depth of 38 feet. Most of the bay, however, is less than 16 feet deep.

\section{COASTAL PLAIN}

This is a plain that slopes very gently from the lagoons to the hilly upland. Its southern limit is approximately an east-west line passing through the town of Río Piedras. The plain has been built up by the accumulation of alluvial and colluvial sediments derived from the uplands to the south; it is, in fact, a series of coalesced alluvial fans which is slightly dissected by small streams and broken at several places by isolated low hills of lower Miocene rock.

\section{PROMINENT HILLS IN COASTAL PLAIN AND MANGROVE SWAMPS}

Several very prominent hills rise abruptly from the featureless coastal plain and from the mangrove swamps at the west edge of the Laguna San José. The largest of these hills, the Montes de Caneja, in the western part of the San Juan quadrangle, extends as an east-west ridge for $11 / 2$ miles and rises with steep rocky flanks out of the flat alluvial coastal plain to a maximum altitude of 330 feet. Less than half a mile to the east is a similar east-west ridge, the Montes de San Patricio, that rises to an altitude of 270 feet. Several smaller knobs crop out on the west shore of the Laguna San José, although at the time the present study was being made these were being rapidly destroyed by quarrying. These conspicuous hills are composed chiefly of thick-bedded, light-colored limestones, with lesser quantities of marl and sand, all of early Miocene age. The peculiar steep-sided shape assumed by these hills is typical of the karst topography that characterizes the outcrop of these rocks along much of the Puerto Rican north coast.

In contrast to the haystack hills formed by the dense limestone, the rather rounded, soil-covered low hills between Suchville and the Montes de Caneja, as well as the five small conical hills between the Montes de San Patricio and the east edge of the quadrangle, consist principally of sand, clay, and marl that stratigraphically underlie the dense limestone.

\section{UPLANDS}

All the area south of the coastal plain is included under this heading, although some of the land is of low altitude and there is considerable diversity of topography. The essential factor of the uplands is that the topography has been eroded in the deformed rocks of the older complex (see under "General geology"), which crop out in the hilly to mountainous interior of the island. The upland topography, in a general way, increases in relief and ruggedness to the south toward the insular divide. This tendency is expressed in the small area of upland encompassed in the San Juan area, where the topography exhibits many of the land forms and the steplike discordances that are characteristic of the island's topography as a whole.

East of Río Piedras the upland rises conspicuously from the coastal plain with the Montes de Hatillo. This mile-wide ridge, which extends to the west for over 5 miles ending abruptly at Río Piedras, is a cuesta composed chiefly of well-bedded ashy and siliceous rocks. A similarly constituted but northeast-trending cuesta is found along the western margin of the mapped area. Between these two ridges an expanse of low-lying, gently dissected "upland" forms a transition between the coastal plain on the north and the more hilly land to the south.

To the east the general surface rises gradually from this low area, and hills and ridges formed of more durable rock rise here and there above the general level. To the south, however, the hills start rather abruptly with the well-defined scarp of the Guaynabo fault (pl. $3 A, 7 A$ ). This is the northernmost of several northwest-trending fault scarps which raise the general upland level in progressive steps southward. The Guaynabo fault scarp, though much dissected, presents a conspicuous front some 225 feet to 320 feet high. The highest points on this fault block lie at altitudes of about 590 feet. The Guaynabo fault block is separated by the northwest-trending valley of the Río Guaynabo from the next scarp to the south, which raises the general level by another 320 feet to altitudes of about 915 feet. This scarp is much dissected, and it is in this block that the rugged terrain typical of much of the interior of Puerto Rico is encountered. The slopes and stream gradients are steep, and the thickness of soil cover is variable. In many places extensive rock outcrops occur only in stream beds (pl. $9 A$ ), though outcrops are also scattered here and there on slopes and divides. 
The topography of the upland is partly adjusted to the varied erodibility of the many rocks that make up the older complex. Outcrops of the granodiorite porphyry and the Trujillo Alto limestone particularly show a tendency to be marked by valleys or areas of low, subdued relief. Fault lines and zones of dense jointing have also been etched out by selective stream erosion, and the prevailing northwest alinement of stream valleys in the southern part of the mapped area is attributed to this type of control.

\section{VALIEY OF THE RIO GRANDE DE LOFZA}

The Río Grande de Loíza, rising south of the San Juan area at the island divide, is the largest river of Puerto Rico. Its watershed, of about 225 square miles, receives an average annual rainfall of about 76 inches. The river flows north along the eastern edge of the mapped area and leaves the Aguas Buenas quadrangle at Trujillo Alto, where it makes a sharp bend toward the east.

The valley sides are 650 feet and more high at the southern end of the mapped area and decrease rapidly in height downstream. The river is flanked by a narrow, slightly terraced, gravelly flood plain that widens considerably where the river course bends sharply eastward at the town of Trujillo Alto.
This alluvium provides the principal source of construction gravel in the area.

The minimum recorded flow of the river, as compiled in studies for the new Loíza dam (p. 44), is 48 cubic feet per second. The maximum recorded flow is estimated at 125,000 cubic feet per second. This was attained for half an hour during the nearhurricane storm of August 4, 1945. The average flow of the river is probably somewhat more than 500 cubic feet per second (Fox, 1951, p. 33). Foundation excavation for the Loíza dam of the Puerto Rico Aqueduct and Sewer Authority, located 13/4 miles south of Trujillo Alto, showed that in this stretch the river flows on both a rocky bed and a thin deposit of sand and gravel that undoubtedly is moved as bed load during periods of higher river stage and greater flow velocity.

\section{GENERAL GEOLOGY}

The San Juan area of this report, though small, contains rocks representative of nearly the full range of geologic ages known on Puerto Rico. The rocks are of Late Cretaceous(?), Late Cretaceous, Paleocene or early Eocene, early Miocene, possibly Pliocene, Pleistocene, and Recent ages, as shown in the stratigraphic summary given below.

Stratigraphic summary of the San Juan area, Puerto Rico

\begin{tabular}{|c|c|c|c|c|}
\hline $\begin{array}{l}\text { Goneral dosig. } \\
\text { pation }\end{array}$ & Stratigraphic unit & Brief description & $\begin{array}{l}\text { Approx. } \\
\text { thickness } \\
\text { (feet) }\end{array}$ & Age \\
\hline & Made-ground and fll. & & & \multirow{5}{*}{ Recent } \\
\hline & Beachrock pavement............ & 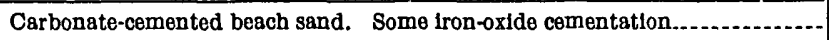 & $-\ldots$ & \\
\hline & Recent littoral deposits......... & 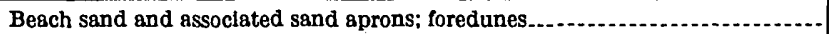 & ................. & \\
\hline & Floodplain alluvium........... & Mostly sllt and clay & -.............. & \\
\hline & Bay mud......................... & Soft black mucky silt and clay & (................ & \\
\hline & Plelstocene littoral deposits.... & Reef rock, eollanite, and paleosols & ................ & Pleistocene \\
\hline & Santurce sand..................... & Quartz sand and white clayey sand $\ldots$ & $-\ldots . . . . . . . . . . .10$ & 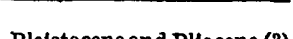 \\
\hline & Older alluvium................... & Red sllty to sandy clay & ................... & Felstuctine and riocene(t) \\
\hline \multirow{5}{*}{$\begin{array}{l}\text { Middle Tertiary } \\
\text { sequence. }\end{array}$} & Aymamón Jimestone............ & 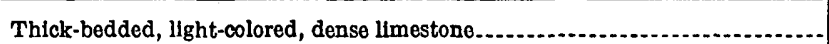 & $950+$ & \multirow{2}{*}{ early Mlocene } \\
\hline & Aguada formation................ & Frisble sandstone, clay, and concretionary limestone & 325 & \\
\hline & Intruslve Igneous rocks......... & Diabase, granodiorite porphyry, and augite andesite porphyry & & \multirow{3}{*}{$\begin{array}{l}\text { early Eocone (?) or late } \\
\text { Paleocene (?). }\end{array}$} \\
\hline & Fajardo formation............... & $\begin{array}{l}\text { Light-colored ashy siltstone, slliceous siltstone and chert, interfingering gray- } \\
\text { waycke, conglomerate, and impure limestone... }\end{array}$ & $3,000+$ & \\
\hline & Figuera volcanics. ............... & Hornblende andesite breccia, minor flow, limestone member at base........... & $>3,000$ & \\
\hline \multirow{6}{*}{ Older complex.... } & Trujillo Alto llmestono... & Fosslllferous medium-bedded to massive limestone & $800-$ & \multirow{4}{*}{ Late Cretaceous } \\
\hline & Monacillo formation........... & Graywacke and conglomerate; commonly red or purple & 900 & \\
\hline & $\begin{array}{l}\text { Fralles formation (Lepro- } \\
\text { comio limestone member } \\
\text { and La Muda limestone } \\
\text { member). }\end{array}$ & $\begin{array}{l}\text { Massive lapilli tuff with some stratifled shale, siltstone, and graywacke. } \\
\text { Leprocomio limestone member at top and La Muda limestone member near } \\
\text { base. }\end{array}$ & 2,350 & \\
\hline & Tortugas andesite................ & Augite andesite breccla and flows & 1,300 & \\
\hline & Guaynabo formation............ & 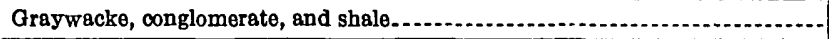 & 4,500 & \multirow{2}{*}{ Late Oretaceous (?) } \\
\hline & Hato Puerco tuff................. & Massive volcanles and metavolcanics and some stratified ash..................... & (?) & \\
\hline
\end{tabular}


The older rocks, that is to say, those of Cretaceous and early Tertiary age, are highly deformed and faulted. They comprise a sequence of volcanic flows, pyroclastics, and sedimentary rocks, but many of the last consist largely of reworked volcanic material. Into these rocks have been intruded plugs, dikes, sills, and larger subjacent bodies that range in composition from granodiorite porphyry to diabase.

Unconformably overlying the Upper Cretaceous and lower Tertiary complex in the San Juan area is a sequence of sands, clays, marls, and limestones of early Miocene age, which have been tilted to the north and faulted on a small scale but which are otherwise undeformed. These rocks probably underlie most of the coastal plain alluvium.

Many of the events following the deposition of the early Miocene sediments are difficult to reconstruct, but certainly both deposition and erosion occurred, brought about by fault-block movement and crustal warping as well as by eustatic changes of sea level. Some of the sediments of the coastal plain and the old alluvial blanket of parts of the uplands were undoubtedly genetically associated with late Tertiary tectonic movements. The rocks of San Juan island and the Santurce hills probably owe their origin in part to higher sea levels, whereas lower sea levels probably account for the deep erosion and alluvium shown by borings about the bay, and for the ancient sand dunes now preserved as offshore rocks (see chap. B).

\section{OLDER COIMPLEX}

The much deformed rocks that crop out widely in the hilly and mountainous parts of Puerto Rico constitute the most interesting and challenging geological element in Puerto Rico. These are the oldest rocks in the island and record the longest and most varied history of crustal disturbances. Their story, if it could be told with certainty, would explain much of the geologic history of this segment of the Antilles.

The works of the several authors of the New York Academy of Science's "Scientific Survey of Porto Rico and the Virgin Islands" (Berkey, 1915; Fettke, 1924 ; Hodge, 1920; Hubbard, 1923; Mitchell, 1922; Semmes, 1919; Meyerhoff and Smith, 1931) treat the older rocks at some length and from somewhat diverse points of view; and the geologic maps of these reports (later compiled into a single geologic map of Puerto Rico by Meyerhoff, 1933) convey a general picture of their natural classification, distribution, and structural trends.

C. P. Berkey (1915) first referred to this complex of rocks as the "Older Series," and Fettke (1924), Meyerhoff and Smith (1931), and Semmes (1919) continued this usage, finding it a convenient term to distinguish these rocks from the clearly younger and relatively undisturbed rocks of middle Tertiary age, which they referred to as the "Younger Series." Hubbard (1923), on the other hand, preferred the terms "Cretaceous formations" and "Tertiary formations" to distinguish the two rock sequences, while Hodge (1920) and Mitchell (1922) used no group terms to separate the two sequences. It is, however, both convenient and desirable to distinguish between the two groups of rocks. Unfortunately Berkey's term, "Older Series," cannot be used because of the special connotation the word "series" has in stratigraphic nomenclature, while Hubbard's simple Cretaceous and Tertiary classification no longer pertains, now that the early Tertiary is known to be included in his Cretaceous (Kaye, 1956). The term "older complex" is therefore used in this paper as a substitute for Berkey's "Older Series."

The nomenclature adopted for this report differs considerably from that used by earlier writers on the area. The geologic map of Semmes (1919) includes a strip 2 miles wide within the western border of the area mapped in this study. In this area Semmes shows the older complex as several northeast-trending belts which he classifies according to lithologic types but to which he does not assign formational names. Meyerhoff and Smith's (1931) map of the Fajardo district includes the entire area of the present study and overlaps the narrow strip of Semmes' map. Both Meyerhoff and Smith's and Semmes' maps are essentially in accord in the overlapped strip. Meyerhoff and Smith gave their map units formational names (fig. 3), including several that were first proposed by Berkey (1915).

A comparison of plate 2 and the Meyerhoff and Smith geologic map of the Fajardo district reveal several profound differences in structure and the distribution of lithologic types. These divergencies are of such weight that many of Meyerhoff and Smith's formational units could not be identified or applied in the field. The fact that the terrain is badly fragmented by faults prevented the writer from constructing a stratigraphic classification of his own until the rather complete and apparently undis- 


\begin{tabular}{|c|c|c|c|c|}
\hline \multicolumn{2}{|r|}{ Meyerhoff and Smith (1931) } & $\begin{array}{c}\text { Possible } \\
\text { equivalence }\end{array}$ & \multicolumn{2}{|l|}{ This report } \\
\hline Age & Formation & & Formation & Age \\
\hline 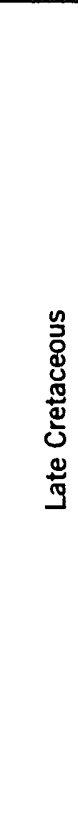 & 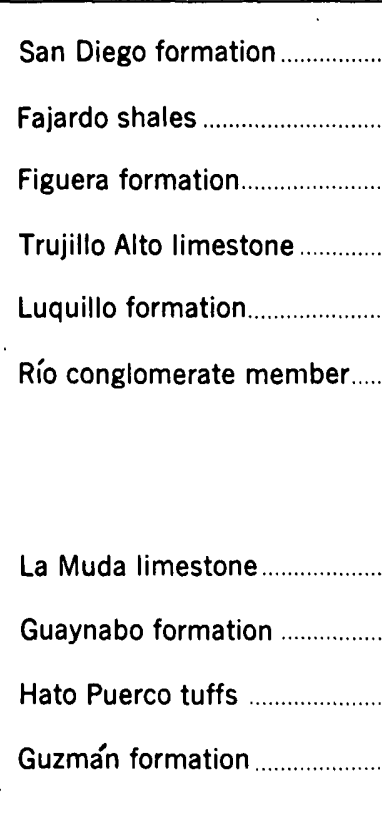 & & 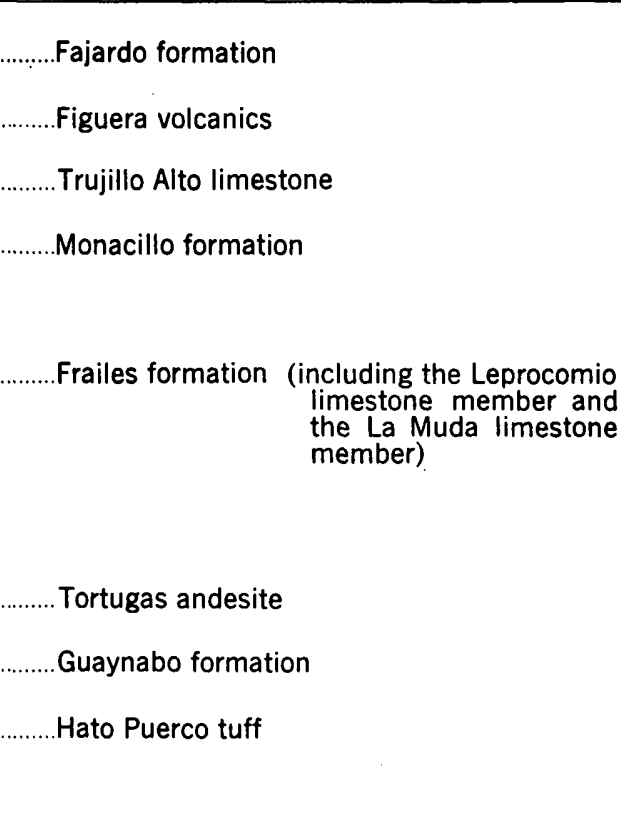 & 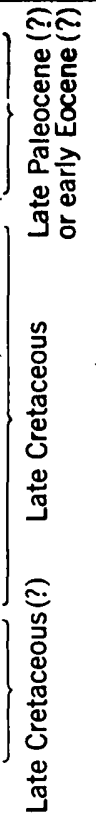 \\
\hline
\end{tabular}

Fiqure 3.-Stratigraphic nomenclature of the older complex in the San Juan area.

turbed section in the eastern part of the area was studied. It is realized, however, that the formations finally adopted for use in this report, although considered valid for the San Juan area, may not apply in other sections of Puerto Rico.

The key to the stratigraphy of the older complex in the mapped area is considered to be the section exposed southeast of Río Piedras, in the Montes de Hatillo. Fortunately, this section is traversed by a road, the sides of which permit a fair picture to be had of the sequence of rock types. This road is Highway 181, which connects the town of Trujillo Alto and the eastern suburbs of Río Piedras, and Highway 175 , which intersects Highway 181 on the north bank of the Río Grande de Loíza and follows the left bank of the river for several miles. Highway 181 crosses the cuesta of the Montes de Hatillo, and successively older rocks are exposed from north to south. In comparison with the terrain to the southwest, remarkably little faulting occurs along this traverse and the stratigraphic sequence is considered to be more or less intact.

The formational breakdown was made on the basis of (1) changes from continental to marine deposition or (2) marked lithologic breaks. The great variability in thickness and the similarities in lithologic types within the several formational units, however, often made their recognition in the field a matter of some uncertainty. The persistence of a rather monotonous suite of pyroclastic facies throughout the section and the difficulty of interpreting the nature of deeply weathered rocks proved particularly troublesome in mapping.

Before describing the individual map units a brief summary of the probable depositional history of the older complex in the San Juan area may be helpful in understanding the characteristics of the several formations and their stratigraphic relations. These rocks are thought (see p. 40 for discussion) to constitute an interfingering sequence of marine and nonmarine deposits such as would occur at the edge of a volcanic island that is undergoing subsidence. Such an island probably marked eastern Puerto Rico in Late Cretaceous time (see Meyerhoff, 1933, p. 43-53). It consisted of a central core made up entirely of pyroclastic and flow rocks that were extruded during an early period of cone construction. Its broad flanks in places were covered with alluvial 
deposits and in others were dissected by erosion (fig. 4). Lapping onto the lower flanks of the cone were estuarine and marine sediments. Subsidence of the insular volcano, either steadily or sporadically, brought overlap of marine deposits onto the eroded and alluviated flanks of the cone, and for part of its history the entire cone may have foundered beneath the sea. Periodic eruptions furnished ash to the surrounding seas and built out the island's shores with new ejecta. Because of such a sequence of events an alternation of continental and marine deposits was produced. Moreover, occasional eruptions from submarine vents low on the flanks of the cone disrupted or shattered the blanket of marine sediments that had been quietly forming on the shallow sea floor, while farther away from the island, in deeper water, marine deposition may have continued uninterrupted during this long history of periodic eruption and quiescence that so effectively left their varied marks on the flanks of the cone.
Such a geological picture seems to explain best the older complex rocks in the San Juan area. The great thickness of volcanic rocks in the region about Caguas, well to the south of the San Juan area, may represent accumulation from a major vent and therefore the central part of the main cone. The rocks of the San Juan area give evidence of having been deposited approximately on the critical zone of marine and insular interfingering that possibly marked the oscillating edge of the "Caguas volcanic island". The thickening and thinning of the older complex deposits in the San Juan area and their rapid changes of facies can readily be explained by the presence of pronounced local erosional disconformities within the section and the instability of the depositional environment. The recurrence of lithologically similar rock types within the section is therefore possibly the expression of the recurrence of certain events and environments during the long history of the volcano and, more precisely, of

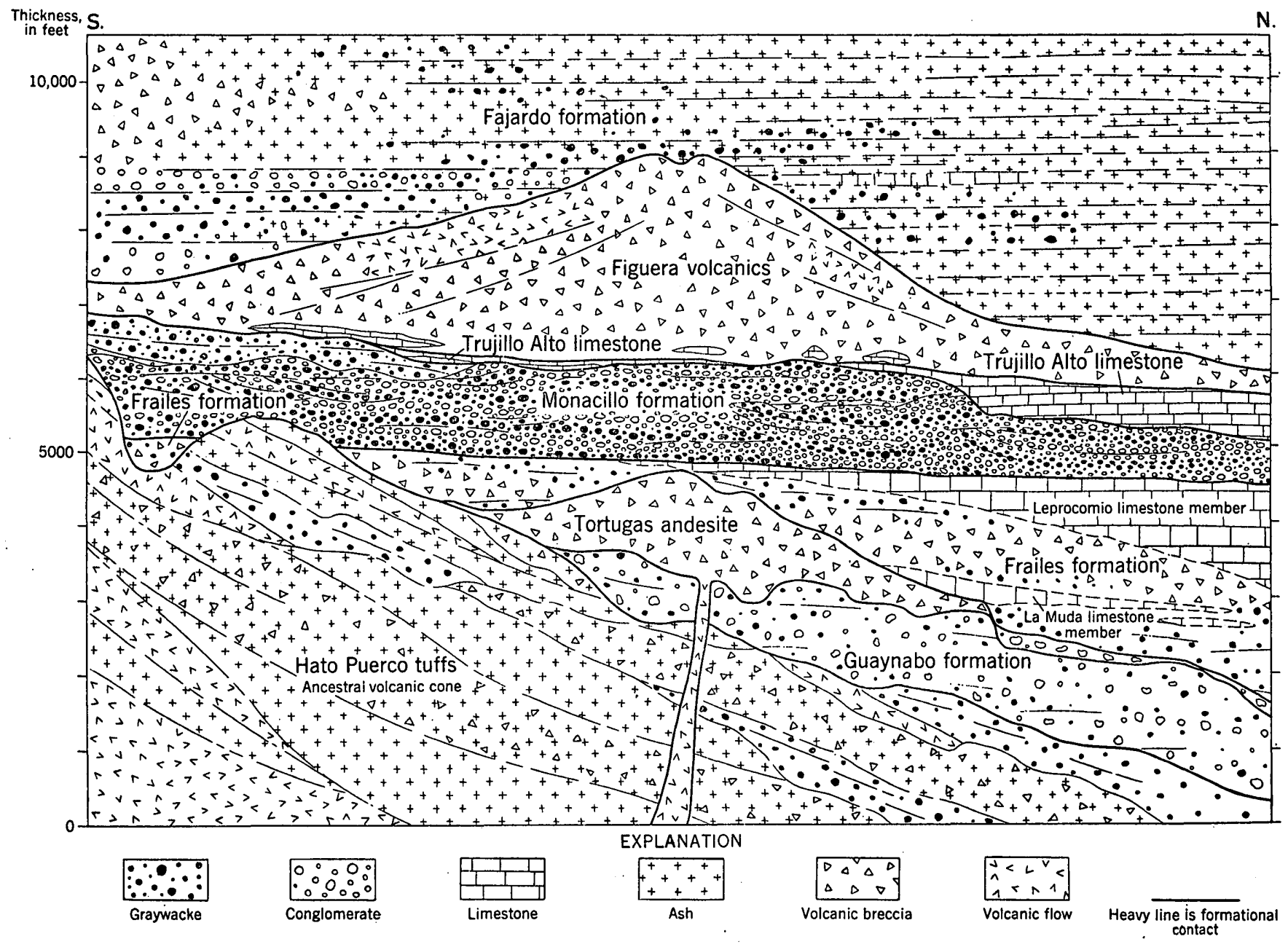

FIGURE 4.-Schematic reconstruction of depositional relations of the older complex in the San Juan area. 
the periods of eruption and quiescence that characterize the later history of many volcanos.

\section{HATO PUERCO TUFF}

This formation was named by Meyerhoff and Smith (1931), who described it as a thick sequence of predominantly unstratified tuff and minor volcanic flows that lie between the Guzman formation and the Guaynabo formation in the western part of the Fajardo district. Although the Guzman formation does not crop out in the San Juan area and the Guaynabo formation is redefined in the present study, the identity of the Hato Puerco tuff was readily established in the area mapped.

The Hato Puerco tuff consists characteristically of massive pyroclastic rocks with some thick sections of flow rock. There are in addition some well-bedded to obscurely bedded tuffs. The whole section encompasses a very wide variety of rocks, although the general criteria for recognition are massiveness, a greater than usual density and toughness where not too greatly altered by weathering, a prevailing deepgreen to dark-blue color, and a degree of regional metamorphism that is somewhat greater than that which characterizes most of the later rocks. The glasses seemed to have been entirely devitrified, the feldspars are invariably very much albitized or saussuritized, and the mineral components in general show various effects of low-grade regional metamorphism. The criterion of metamorphism in itself cannot be universally applied, for alteration similar to that of the Hato Puerco rocks can be found here and there throughout the section of the older complex.

The variability of the Hato Puerco tuff can be shown by a review of some of the types found in the San Juan area. Very dense, hard, dark blue-gray aphanitic to finely porphyritic rocks, which break into sharp angular fragments, occur in several places, perhaps most widely on the north side of the ridge that follows Highway 1 southeast of La Muda. Under the microscope this rock is seen to be a much altered tuff made up of both crystal and lithic fragments. It consists predominantly of angular broken crystals of chloritized andesine-laboradorite, scattered biotite and pyroxene, some nests and isolated grains of quartz, and a few subangular fragments of a much altered trachitic-textured rock. The interstitial material is a very fine aggregate of feldspar, quartz, and probably devitrified glass. Both the groundmass and the coarser fraction are much altered to chlorite. Clusters and randomly oriented needles of green clinoamphibole $\left(Z \vee c 21^{\circ}\right)$ are common in both the coarse fraction and the matrix.

An interesting altered tuff crops out southeast of La Muda $(197,900 \mathrm{~m}, 54,430 \mathrm{~m})$. This rock, a thin section of which was studied by Robert L. Smith of the U. S. Geological Survey, is a metamorphosed pumiceous tuff that was originally composed of small fragments of pumice, fragments of plagioclase crystals and scarce grains of pyroxene. According to Smith "the glass has been completely replaced by alkalic feldspar without loss of original pumiceous texture. The alkalic feldspar, as nearly as can be determined by optical and X-ray methods, is albite. The vesicles in the replaced glass are filled with chlorite. Chlorite also occurs, interstitial to the component fragments. The ubiquity of the chlorite together with the scarcity of relict ferromagnesian minerals or 'ghosts' of these minerals suggests that the original glass was rather basic in composition, and during its replacement by albite the ferromagnesian constituents went into chlorite. There are numerous tiny spherulitic grains of epidote scattered throughout the areas of chlorite. The plagioclase feldspar is partly altered to sericite mica and carbonate."

Stratified rocks of the Hato Puerco tuff are of a variety of types and in general seem to be relatively thin and nonpersistent. Laminated to thinly bedded light- and dark-gray tuff consisting of fine crystalline material, ranging in grain size from that of fine sand to silt (this textural classification is convenient for field description based on touch and hand-lens inspection), crop out widely in the southern part of the mapped area. Obscurely bedded ash that was weathered to a soft yellowish silty material wherever seen is another common type.

Coarse-grained volcanic breccias are common in the Hato Puerco tuff. Again, these rocks are dark green to blue gray, dense and tough. Matrix as well as fragments are equally indurated, and the rocks break across the constituent grain. Thin sections reveal that the more common lithic particles are subangular to subrounded fragments of dark-colored vitrophyres, now devitrified and variously altered to hematite. In addition there are fragments of very fine grained trachitic rocks and palagonite tuffs. The interstitial material contains broken albite crystals, quartz, and matter too finely comminuted to be identified under the petrographic microscope. Secondary zoisite and chlorite are common. Rocks of this type are found in several of the quarries along the valley of the Río Grande de Loíza south of Trujillo Alto. 
Within the Hato Puerco tuff, thick sections of flow rock are not uncommon. The thickest development of these in the vicinity of San Juan occur along the valley of the Río Bayamón on the Naranjito quadrangle, just to the west of the southwestern part of the San Juan area. Here, several large quarries expose spilitic pillow lavas. In texture these rocks range from aphanitic to finely porphyritic amygdaloids, typically of a medium greenish-gray color ( $5 G$ 5/1). A thin section of the porphyritic rock shows about 40 percent phenocrysts of zoned albite up to $3 \mathrm{~mm}$ in length and small stubby augite crystals. The groundmass consists of a felt of fine albite laths. Some glass may originally have been present in the groundmass, but it is now obscured by secondary chlorite and actinolite, which has replaced much of both the groundmass and the albite phenocrysts. Much ore dust is present throughout, as well as minute epidote clusters. The numerous vesicles in the thin sections studied are filled with chlorite, in radial arrangement, and prehnite.

Other metavolcanics of the Hato Puerco tuff are not too dissimilar in appearance and gross physical properties to these spilites. The tough, fine-grained dark-blue meta-andesites that crop out along the Río Grande de Loíza, about 11/2 miles south of Trujillo Alto, are not, however, spilitic in composition. Here the phenocrysts are andesine, though the degree of alteration is so intense that the nature of the original groundmass is difficult to determine. The development of fine actinolite in this rock is particularly prominent. Samples of other dense, finegrained dark bluish- to greenish-gray rocks of the Hato Puerco tuff show the same extensive development of green clinoamphibole $\left(Z \vee c 15^{\circ}-23^{\circ}\right)$ of metamorphic origin.

In the San Juan area the Hato Puerco tuff occurs in the south and southeast, in the area of more hilly topography. The formation appears to crop out widely to the south and east of the mapped area, and in it may probably be included many of the massive rocks that make up much of the central interior of the eastern part of Puerto Rico.

No estimate is made of the thickness of the Hato Puerco tuff exposed in the San Juan area, owing to the prevailing massiveness of the formation. Such attitudes as can be determined in the stratified members are considered unreliable structural guides, particularly in the absence of information on faults and of their displacement.
The Hato Puerco tuff probably formed the main mass of the volcanic cone or cone complex ("Caguas island") which has been discussed above. The position and approximate size of this volcanic island is suggested in a diagrammatic reconstruction by Meyerhoff $(1933$, p. 50). The volcanic cone origin of the Hato Puerco tuff probably accounts for both the unconformable and the conformable relations with the overlying formation (Meyerhoff and Smith, 1931, p. 272) and also for the fact that it is overlapped by rocks higher in the sequence. On the lowermost and, presumably, the flattest slopes, the thick sections of alluvium which make up most of the overlying Guaynabo formation may well have ben conformable with the thick ash deposits. Alluvial and marine sediments deposited against the eroded slopes, on the other hand, would for the most part be strongly unconformable with the stratification of the composite cone (fig. 4).

Age.-No fossils have been found in the Hato Puerco tuff. The entire older complex of Puerto Rico was thought to fall within the Upper Cretaceous by Meyerhoff and Smith (1931). More recent work has revealed, however, that Paleocene or early Eocene faunas, as well as Late Cretaceous faunas, occur in the older complex (Kaye, 1956). The rational basis for confining all older complex rocks to the Upper Cretaceous is therefore destroyed in one time direction, which raises some question as to the necessity of assigning a Late Cretaceous age to the oldest rocks in the section, particularly since they are unfossiliferous. At the present time, for want of any evidence to the contrary, the Hato Puerco tuff is designated Late Cretaceous(?) in age. It is possible, however, that they are Lower Cretaceous.

\section{GUAYNABO FORMATION}

The Guaynabo formation consists of several thousand feet of stratified tuffaceous sandstone or graywacke, ${ }^{1}$ conglomerate and shale. Meyerhoff and Smith $(1931$, p. 275) define the Guaynabo formation as a ". . succession of sediments which lie below the La Muda limestone and above the Hato Puerco tuffs in the northwestern part of the Fajardo district. The town of Guaynabo lies near the southwestern edge of the broad formational outcrop. ..." This formation

\footnotetext{
1 The term "graywacke" is used in this report to denote arenites that are of a rather varied mineralogic composition and that are generally shades of gray when unweathered. They may be marine or nonmarine in origin. For the most part the mineral components give evidence of volcanic origin. In some places these rocks could more aptly be called bedded tuffs. The term "graywacke," however, is preferred as a field term, because without the examination of thin sections it is difficult to assess the relative importance of the tuffaceous component.
} 
is here redefined, however, inasmuch as the study of the section in the Trujillo Alto road and the distribution of rocks elsewhere in the San Juan area indicates: (1) that in several places these sediments are sharply terminated above by volcanic rocks (the Tortugas andesite); (2) that in the several places where it is recognized, the La Muda limestone, as defined on page 18, rests either on this volcanic sequence or is separated from the volcanic horizon by a varied thickness of noncarbonate beds (the Frailes formation); and (3) that the beds cropping out in the vicinity of the town of Guaynabo do not include sedimentary rocks having the stratigraphic position given by Meyerhoff and Smith. The limits of the Guaynabo formation are therefore drawn to include only the section of noncarbonate sediments overlying the Hato Puerco tuff and underlying the Tortugas andesite or, where this latter horizon is missing, the Frailes formation. The upper part of the Guaynabo formation is well exposed in the sides of Highway 175, across the Río Grande de Loiza from the town of Trujillo Alto. Here at least 550 feet of medium- to thick-bedded, gritty graywacke and intercalated gray shales and conglomerate are exposed.

The same beds crop out broadly in Barrio ${ }^{2}$ Caimito and Barrio Cupey, northeast and west of the Escuela Segunda Unidad de Caimito; and are particularly well exposed in a deep road cut on the new Highway 1, a little more than half a mile south of El Minao. The road cut shows a plunging anticline in well-bedded, gritty graywacke with minor intercalated shale and fine-grained conglomerate. Flecks of carbonized plant remains are rather common throughout and locally are very abundant. In the creek bed close to the road cut where the graywacke is relatively fresh and unweathered, it is a tough rock, light to medium blue-gray in color; but in the road cut nearby, it is weathered to a brown very friable sandstone and even a loose sand.

In other places, the Guaynabo formation contains beds of very fine ash or siltstone, which break down on weathering to a yellowish soft punky silt. In fact, the rocks of this formation weather rather readily, the shales becoming light-gray to white clays and the sandstones becoming exceedingly friable. Bleached biotite flakes and flecks of carbonized wood are generally conspicuous in the weathered rock and aid in recognition of the formation.

\footnotetext{
2Barrio is the smallest of the Puerto Rican political units. It may be considered a district, ward, or precinct of a municipality (municipio).
}

A certain amount of current-bedding is noticeable in some exposures. Graded bedding is absent or not marked.

The contact of the Guaynabo formation with the Hato Puerco tuff was not knowingly observed by the writer; but this contact, where it occurs in the San Juan area, was inferred to be faulted. It is reported, however, by James P. Owens (written communication) to be exposed along the new section of the Caguas Highway (No. 1) where it is seen to be gradational.

The upper contact of the tuffaceous sandstone of the Guaynabo formation is variable. In the section along Highway 175, west of Trujillo Alto, the formation is overlain conformably by about 10 feet of andesitic conglomerate that is thought to represent the Tortugas andesite. A much thicker section of Tortugas andesite is found overlying the sedimentary rocks of the Guaynabo formation in the southern part of the mapped area, although in places the Tortugas andesite is replaced by an andesite porphyry sill. North of El Minao, the Tortugas andesite is either very thin or absent; and in places the Guaynabo formation is overlain by the Frailes formation.

The Guaynabo formation is possibly nonmarine in origin. Both in its somewhat irregular stratification and prevailingly coarse-grained composition it resembles an alluvial deposit, although, admittedly, the evidence is not conclusive.

The Guaynabo formation may attain a thickness of 4,500 feet in Barrio Cupey, although the lower contact of the formation is an inferred fault. Because the poor exposures in this area do not permit determination of the details of faulting, this thickness is only a rough estimate and may be excessive. It seems likely, however, that the Guaynabo formation partakes of the same variability in thickness as that which characterizes almost all of the formations of the older complex.

Age.-No identifiable fossils have been found in the Guaynabo formation. Since the formation in places seems to be conformable with the younger Frailes formation, which contains a late Upper Cretaceous fauna, it is probably not very much older than the latter rocks and is, therefore, designated as Late Cretaceous( ?) in age.

\section{TORTUGAS ANDESITE}

The Tortugas andesite is named after Barrio Tortugas, lying north and east of La Muda, where it is well exposed. The formation consistis of a nonper- 
sistent horizon of flow rock, breccia, and, in places, conglomerate-all of a characteristic augite-andesite composition-lying between the Guaynabo formation, herein redefined, and the Frailes formation. The formation varies in thickness very rapidly, as for example at El Laberinto where probably over 1,300 feet of volcanic rocks of the Tortugas disappear almost abruptly along the strike and suggests a local vent accumulation at this place.

This stratigraphic unit was not recognized by Meyerhoff and Smith (1931). Its prominent outcrop in the vicinity of La Muda and Trujillo Alto are included in their Guaynabo, Luquillo, and Fajardo formations.

Blocks of sedimentary rock have been noted in the Tortugas andesite at two places southeast of $\mathrm{La}$ Muda. High on the side of the quarry, one-fourth mile north of the intersection of the Aguas Buenas road(Highway 173) and the Caguas road (Highway 1 ), is a large lens of sandstone and conglomerate entirely enclosed by massive andesite. At the road intersection itself $(188,790 \mathrm{~m}, 53,410 \mathrm{~m})$ there are many large and small blocks of a massive, finely crystalline limestone, which seem to be embedded in the andesite but which may possibly belong to a fault zone, as suggested by Mr. Owens (oral communication). These limestone blocks, which do not resemble the La Muda limestone member that crops out nearby just north of the Caguas road, contain abundant rudist fragments and provide the only known occurrence of rudists in the San Juan area. In addition, several mollusks were collected from these blocks. They were examined by John B. Reeside, Jr., who identified Nerinea (Plesioptygmatis) burckhardti Böse, Trochactaeon aff. T. planilateris Böse, and Nerita sp.. According to Mr. Reeside this fauna is certainly of Late Cretaceous age and appears to be close to that from Cardenas, Mexico, which Böse assigned to the lower Senonian (Santonian or Campanian). If the blocks are not due to fault displacement, they may represent ejected blocks of an older limestone; or they may represent limestones, more or less contemporary in age with the eruptions of the Tortugas andesite, that became incorporated in a flow.

The Tortugas andesite is particularly well exposed in several of the quarries that lie north of Highway 1 about a mile southeast of La Muda $(189,000 \mathrm{~m}$, $53,750 \mathrm{~m}$ ) and in a quarry and a road cut about $11 / 4$ miles north of La Muda (188,100 m, 56,800 m). The rocks are somewhat varied in texture and to a certain extent in composition; but they are almost always porphyritic, having small light-colored feldspar phenocrysts in a dark aphanitic groundmass. Mafic minerals, when visible in hand specimen, are generally augite, a feature which makes it possible to distinguish the rocks of this formation from the hornblende-bearing Figuera volcanics.

Fine-grained porphyries, which megascopically are similar to the volcanic rocks of the Tortugas andesite, are common in the conglomerates throughout the section of the older complex rocks in the San Juan area and occur widely throughout Puerto Rico. Whether this indicates that there was a long history of eruption of this type of lava throughout the course of deposition of the older complex, or whether the lavas represent a relatively short-lived, though widespread, eruptive cycle that provided sediment for all later deposition, is not known. In the San Juan area, however, there is evidence that a welldefined single interval of volcanic outpouring from several local vents accounted for the accumulation of the volcanics of the Tortugas andesite.

In the area to the north and east of El Laberinto, the Tortugas andesite is particularly thick and varied. In the several quarries north of Highway 1 , two rocks of somewhat different textures occur. One is a light- to medium-gray porphyritic andesite in which nearly white plagioclase phenocrysts, ranging in size from $1 \mathrm{~mm}$ to $0.5 \mathrm{~mm}$, make up about 30 percent of the rock, embedded in a gray finely crystalline groundmass. The other textural type is a somewhat denser andesite, in which the plagioclase phenocrysts are sparser and, because of their transparency, not readily discernible to the eye. The groundmass is a dark-bluish gray (5B 4/1). A thin section of the latter rocks shows that the feldspar phenocrysts, comprising about 25 percent of the rock, are calcic labradorite $\left(\mathrm{An}_{68}\right)$. Other phenocrysts are euhedral augite, making up about 5 percent of the rock and averaging $0.3 \mathrm{~mm}$ in size, and small euhedral grains of ore. The groundmass consists of minute oligoclase-andesine needles fluidly arranged in a glassy matrix containing abundant small zircons and much ore dust.

In cuts along the road to El Laberinto are exposed the same andesitic rocks as in the quarries to the north and east. Here interbedded breccias, conglomerates, and flow rocks, all of the same finely porphyritic augite andesite, crop out, 


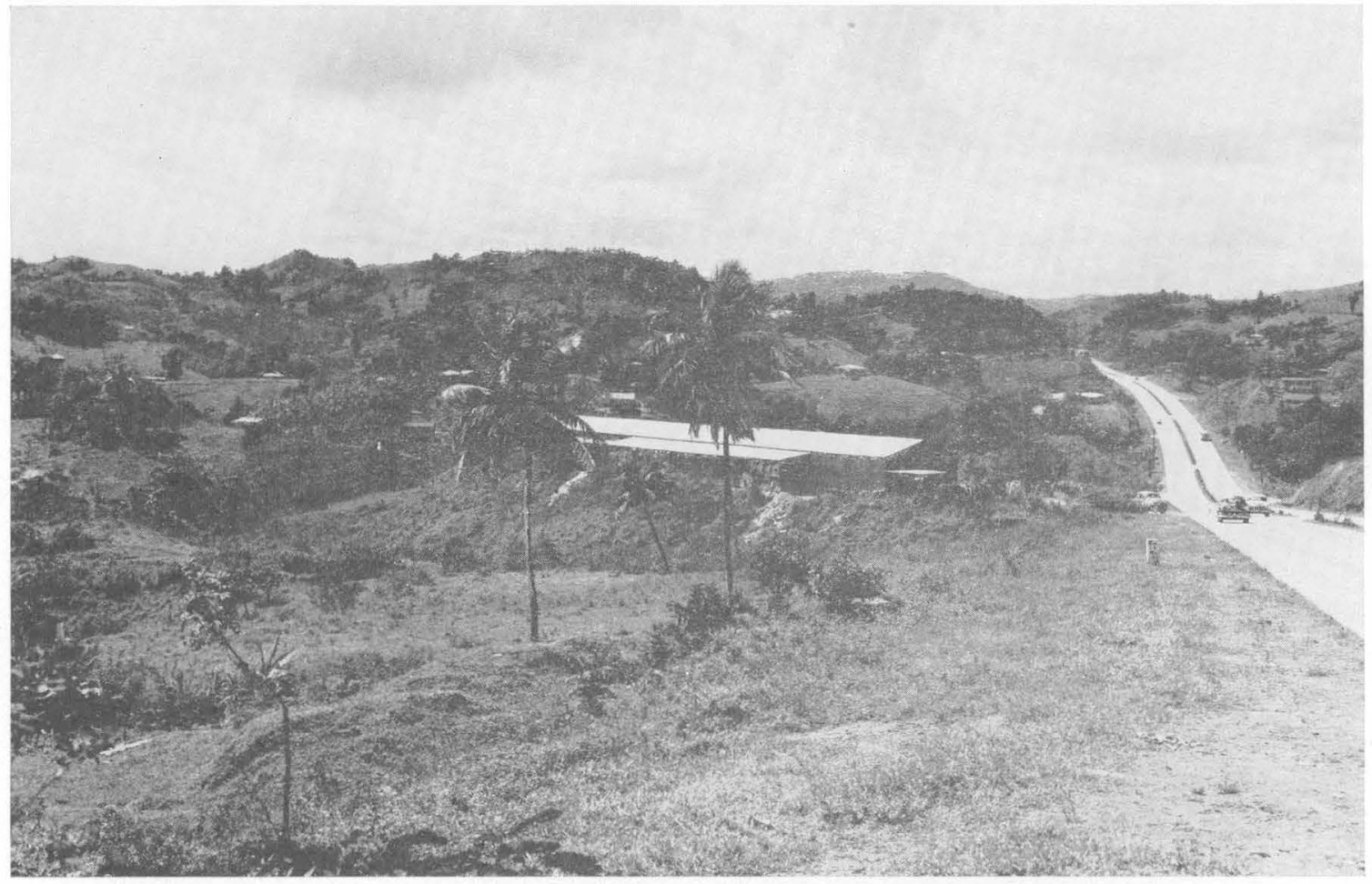

A. VIEW SOUTH ALONG RIOO PIEDRAS-LA MUDA HIGHWAY

Guaynabo fault block shows in middle distance; just visible beyond is the higher fault block to the south

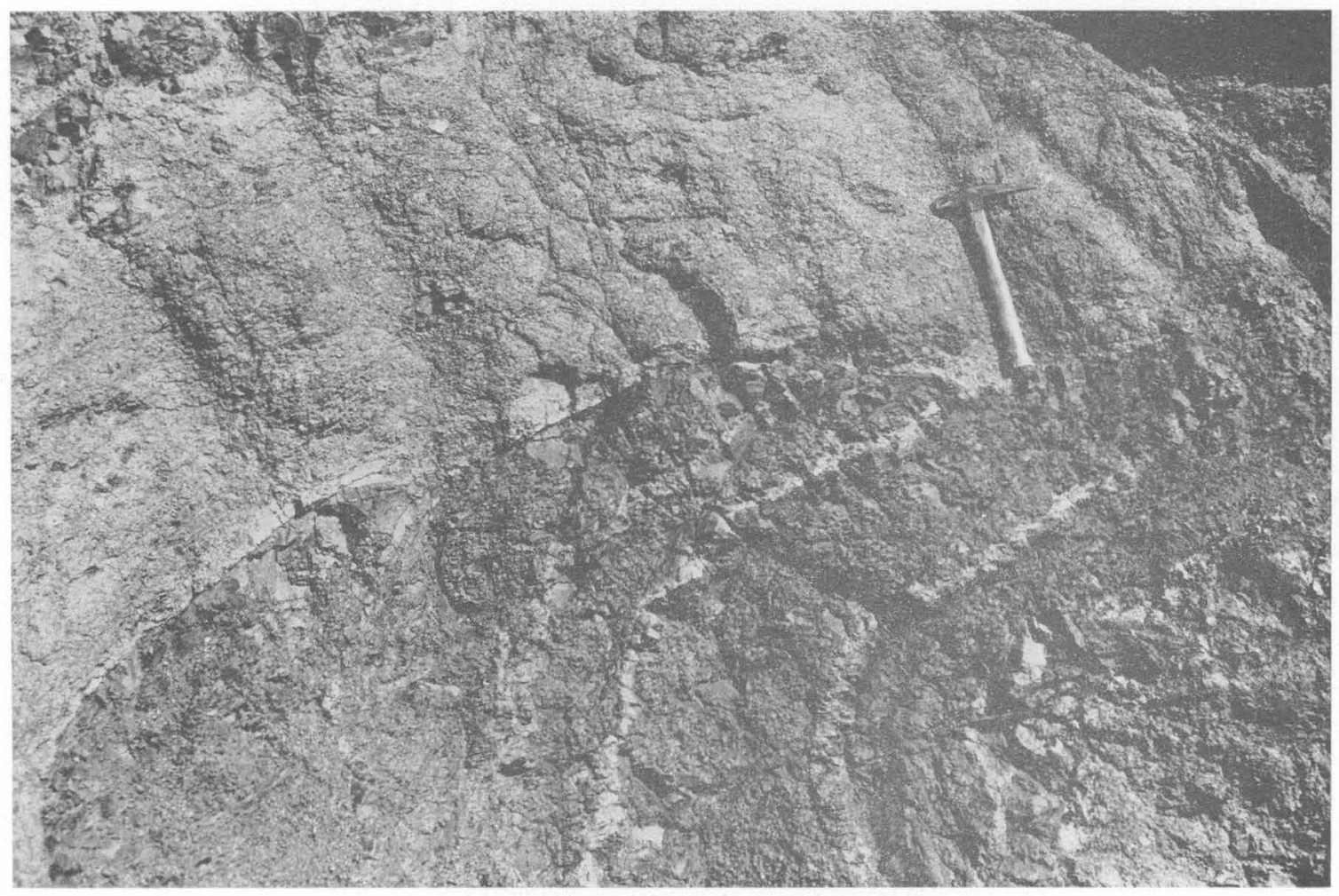

$B$. LARGE CONTORTED SHALE BLOCK IN LAPILLI TUFF OF THE FRAILES FORMATION, ABOUT ONE.FOURTH MILE SOUTH OF EL MINAO 


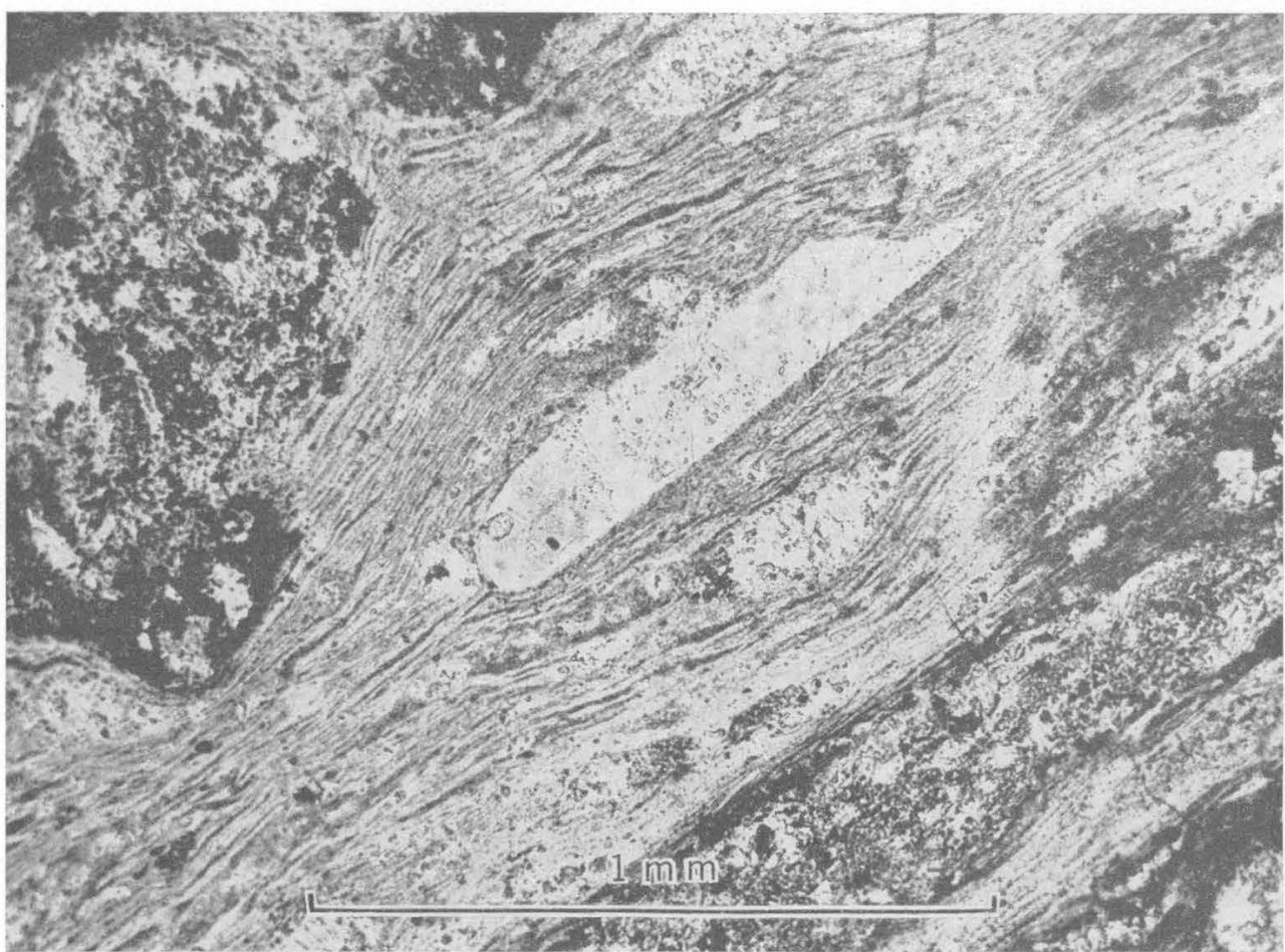

A. BANDED RHYOLITIC VITROPHYRE (WELDED TUFF?) FROM BRECCIA IN THE FRAILES FORMATION

Large, broken and resorbed crystal is albite; clear areas are aggregates of xenomorphic granular quartz; banded material is glass; and finely divided hematite forms the darker streaks and the opaque areas. Magnification $69.9 \times$, plane polarized light

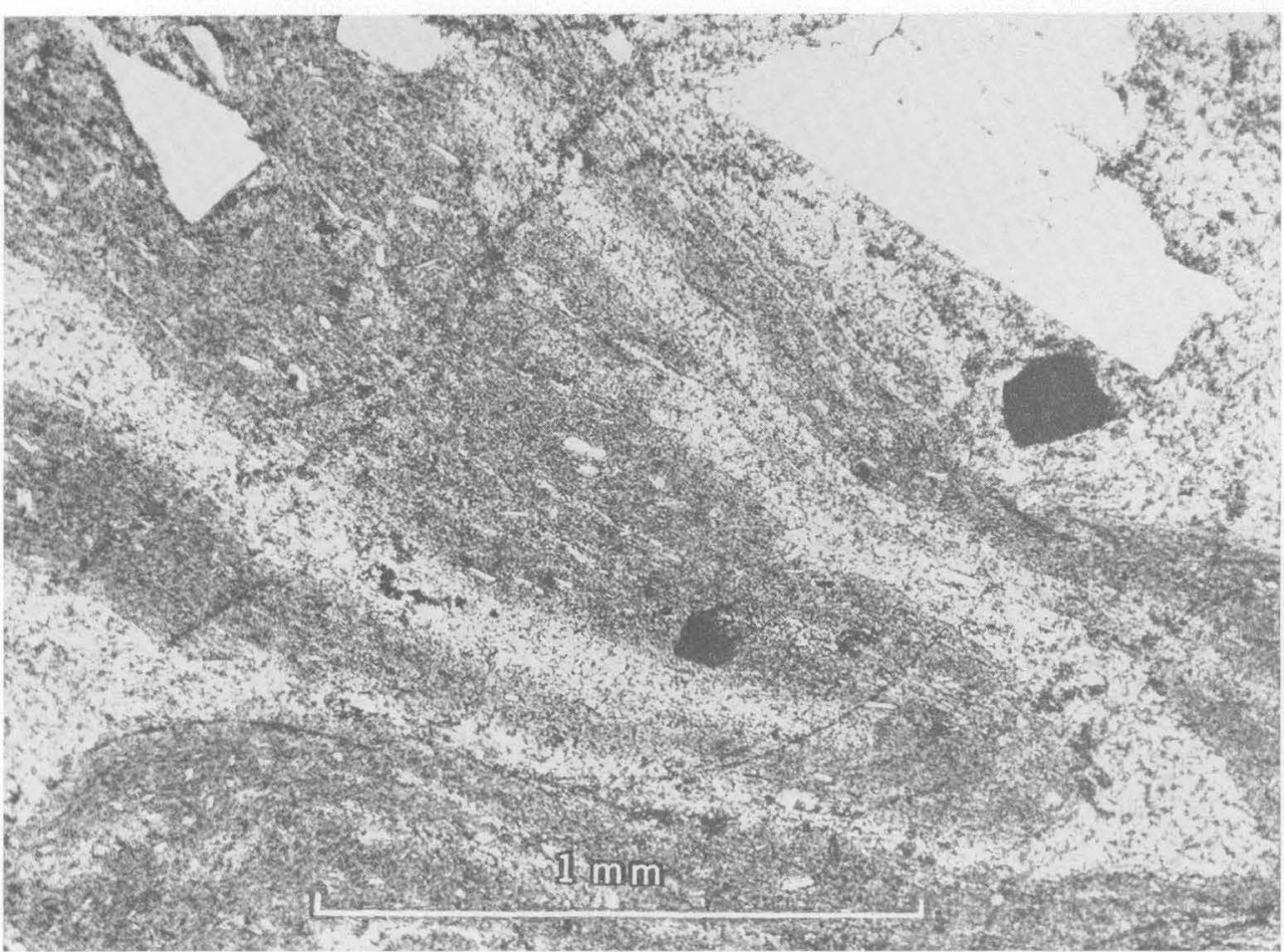

B. VITROPHYRE FROM THE FIGUERA VOLCANICS, SHOWING FLOW STRUCTURE

Dark streaks are glass; light streaks are cryptocrystalline; crystals are plagioclase. Magnification $62 \times$, plane polarized light 
A particularly prominent development of the Tortugas andesite, including a thick section of conglomerate, occurs in an east-west belt over two miles in length and terminates about one-half mile southeast of Guaynabo. Judging from several thin sections, the rocks in this belt are variable in composition and are much altered. They are, however, fairly consistently dark gray with small white feldspar phenocrysts generally up to $2 \mathrm{~mm}$ in length. Variations include a somewhat coarser porphyry with labradorite $\left(\mathrm{An}_{66}\right)$ phenocrysts $3 \mathrm{~mm}$ in length in a grayish-purple (5P 4/2) groundmass that contains small crystals of copper-colored biotite. In thin sections the phenocrysts are seen to include, besides labradorite $\left(\mathrm{An}_{68}\right)$ phenocrysts $3 \mathrm{~mm}$ in length in small shreds, and olivine(?) in small crystals up to $0.01 \mathrm{~mm}$ in length. The groundmass consists of very fine needles of sodic andesine and a mesostasis of very low birefringence that possibly is a partly devitrified glass. Alteration of this rock is advanced, such that labradorite and augite are altered to very fine-grained chlorite and carbonate, and the olivine(?) is altered to chlorite and to carbonate with heavy rims of magnetite and goethite.

Another sample of flow rock showed 10 percent of zoned and twinned andesine-labradorite phenocrysts $\left(\mathrm{An}_{40}-\mathrm{An}_{50}\right)$ up to $3 \mathrm{~mm}$ in length that were much altered to sericite, and about 3 percent of augite up to $0.7 \mathrm{~mm}$ in length, almost entirely replaced by quartz in aggregates of small crystals. Crystals of magnetite are plentiful and in places are large enough to be considered phenocrysts. The groundmass, which makes up about 80 percent of the rock, is a fine xenomorphic granular aggregate of albite and (or) orthoclase, and perhaps quartz with much ore dust. Very small crystals of apatite are abundant in both groundmass and phenocrysts.

A chemical analysis (given below) of a sample of Tortugas andesite from the quarry southeast of La Muda indicates that the composition of the rock is andesitic, although the low $\mathrm{K}_{2} \mathrm{O}$ and $\mathrm{MgO}$ and the high $\mathrm{CaO}$ are all unusual for rocks with a comparable $\mathrm{SiO}_{2}$ content. The composition, however, is not too dissimilar to Daly's (1933, p. 16) averages for both augite andesite and hypersthene andesite. It does not, however, accord too closely with the average andesite composition compiled more recently by Nockolds (1954).
Chemical analysis and parameters of Tortugas andesite, Puerto Rico, and related rocks

\begin{tabular}{|c|c|c|}
\hline - & \begin{tabular}{|} 
Tortugas augite \\
andersite from \\
quarry $1 \mathrm{mill}$ \\
SE of La \\
Muda 1 (weight \\
percent)
\end{tabular} & $\begin{array}{l}\text { Augite andesite; } \\
\text { an average of } \\
\text { 33 analyses 2 } \\
\text { (weight } \\
\text { percent) }\end{array}$ \\
\hline
\end{tabular}

A. Chemical analysis

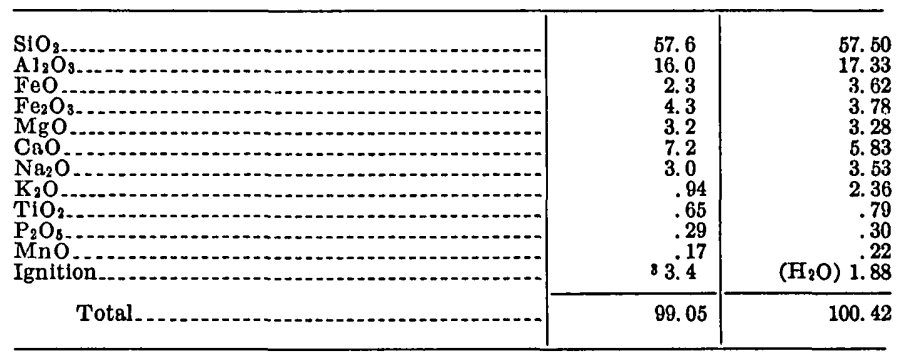

B. CIPW norm,

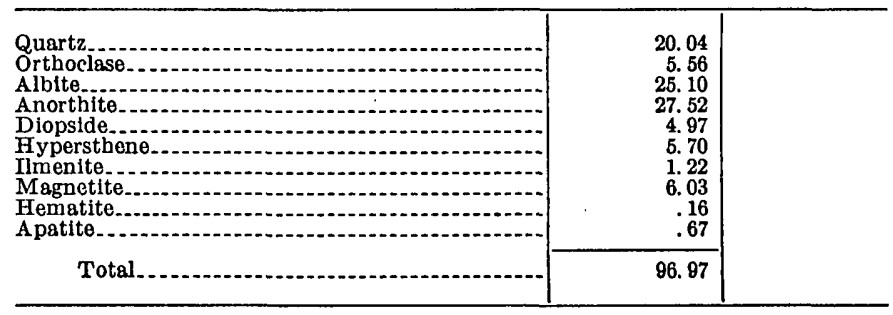

C. Mode

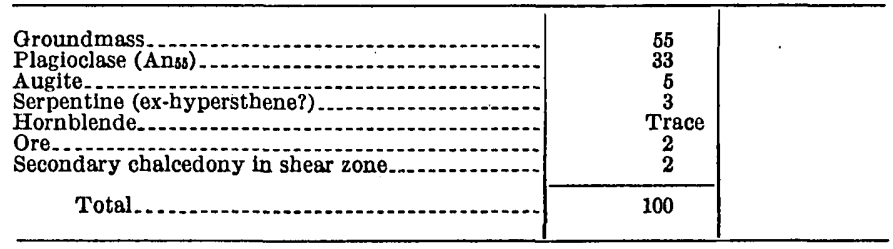

1 Ohemical analysis by rapid methods; analysts, Frank S. Borris, Harry F. Phillips, and Katrine White.

8 Includes gain due to oxidation of $\mathrm{FeO}$

Perhaps the closest norm in Nockolds' tables is that for dacites and dacite obsidians (combined). The high normative quartz (20.04 percent) indicates the bulk composition of a quartz andesite, although this is not reflected in the mode. Two thin sections of the analyzed sample failed to reveal any recognizable quartz, tridymite, or cristobalite except for a thin shear zone filled with minute chalcedonic spherulites. Most of the free silica indicated by the norm probably resides in the groundmass, which is too finely crystalline to permit mineral identification. The serpentine pseudomorphs reported in the mode are, from their outline, possibly alteration of hypersthene. 
FRAIMES FORMATION (INCLUDING THE LA MUDA AND LEPROCOMIO LIMESTONE MEMBERS)

The Frailes formation consists of sedimentary and pyroclastic rocks (particularly a massive lapili tuff) with prominent limestones in the upper and lower parts. The formation is named after Barrio Frailes, east of Guaynabo, in which the formation is well developed.

A typical section of the Frailes formation is exposed in the road cuts on Highway 175 along the left bank of the Río Grande de Loíza west and north of Trujillo Alto, and along Highway 23 north of Trujillo Alto. Here it overlies an andesite porphyry sill. The contact of the Frailes formation with the underlying Tortugas andesite is, however, exposed in the La Muda area in a road cut on the west side of Highway 1 , just west of the El Laberinto road crossing, and also in the immediate vicinity of this hamlet. The upper contact of the Frailes formation with the Monacillo formation is not clearly exposed in the shallow cuts along the road, where the rock is deeply weathered. The total thickness of the Frailes formation in this section is about 2,350 feet, scaled from the map.

Some idea of the wide range of lithologic types included in this formation can be had from the Highway 175 section, where from bottom to top the following rocks are exposed: rudely stratified fine conglomerate and lapilli tuff (about $80 \mathrm{ft}$ ); gray cherty shale ( $3 \mathrm{ft}$ ) ; thick-bedded graywacke with some interbedded tuffaceous shale (about $50 \mathrm{ft}$ ); massive lapilli tuff (about $20 \mathrm{ft}$ ); thick-bedded to thinbedded, gritty to fine-grained, light-colored sandstone (about $59 \mathrm{ft}$.) with interbedded arenaceous fossiliferous limestone (La Muda limestone member); conglomerate (2 ft); light, dove-colored, fissile shale (about $13 \mathrm{ft}$.) ; thick-bedded graywacke with some interbedded thin tuffaceous shale (about 250 $\mathrm{ft}$ ); massive lapilli tuff (about $12 \mathrm{ft}$ ); thin-bedded fine-grained graywacke; mottled and laminated porcelaneous shale (about $50 \mathrm{ft}$ ); massive lapilli tuff with some interbedded graywacke (about $800 \mathrm{ft}$ ); about 1,120 feet of thin- to thick-bedded tuffaceous limestone and interbedded tuffaceous sandstone (Leprocomio limestone member).

The color of the rocks is generally greenish gray when fresh and brown when weathered, although some of the shales are medium to light gray, and part of the massive lapilli tuff deposit northwest of El Laberinto is a very dusky red purple $(5 R P 2 / 2)$, although this is possibly the result of baking by one of several nearby intrusions.
Recognition features of this formation include the two limestone members, thick lapilli tuffs and fine conglomerates, well-bedded argillaceous and finegrained sediments, and the presence of marine fossils.

Perhaps the most characteristic rock type of the Frailes formation is the dark-green lapilli tuff that occurs in the middle part, between the La Muda limestone member and the Leprocomio limestone member. The rock is well exposed along Highway 175 at Trujillo Alto $(197,100 \mathrm{~m}, 58,250 \mathrm{~m})$ and in several new road cuts just north of the Quebrada Frailes crossing on Highway $1(188,700 \mathrm{~m}, 57,820$ $m)$. Other significant exposures can be found on a ridge about three-fourths mile east of Guaynabo and northeast of El Laberinto. All of these sections, except that northeast of El Laberinto, show a series of two or more lapilli tuff horizons separted by shale, siltstone and graywacke.

The pyroclastic section exposed in the cuts on Highway 1 north of the Quebrada Frailes crossing merits special description. The lowermost breccia crosses the highway at the El Minao intersection (unfortunately the interesting west side of this road cut has since been removed by the construction of the new Highway 1). Making allowances for the several faults that are present in this exposure, the following section was distinguished, from bottom to top: (1) Unknown thickness of interbedded gritty graywacke and olive-colored clay shales. (2) Fifteen feet of massive, very coarse breccia with angular fragments up to 6 feet across of banded rhyolitic vitrophyre with well-developed flow structure, coarse- to fine-grained dark porphyries resembling the Tortugas andesite, and pieces of shale and tuffaceous sandstone. The fragments are more rounded and smaller in size towards the top. (3) Approximately $21 / 2$ feet of bluish-gray gritty graywacke overlain by about 4 feet of olive-brown siltstone with marine fossils. (4) About 7 feet of massive lapilli tuff. (5) Four feet of gritty graywacke. (6) At least 18 feet of coarse volcanic breccia similar to bed 2 , above. In the cut on the east side of the highway, the entire section above the base of the tuffaceous sandstone consists of coarse breccia.

The banded rhyolitic vitrophyre fragments (pl. $4 A$ ) found in the lower breccia in this exposure (see bed 2, above), may be of stratigraphic significance because massive deposits of similar rock have been noted at several places in Puerto Rico (Hodge, 1920, p. 171; Meyerhoff and Smith, 1931, p. 288; Semmes, 1919, p. 65; Smith and Hildebrand, 1953). 
The dark-gray and light-pink (white on weathered surface) flow banding is particularly striking. The bands are generally $2 \mathrm{~mm}$ or less thick and the dark bands are discontinuous. Scattered through the rock are small subangular xenoliths, ranging in size up to about $2 \mathrm{~mm}$, around which the dark bands inscribe regular flow lines. The long dimensions of these fragments are not everywhere parallel to the flow banding. In thin section the rock is seen to consist chiefly of slightly devitrified glass containing fluidly alined, fine threads that are richer in iron, and siliceous streaks and lenses made up mostly of spherulites with quartz and small sanidine crystals in the center of the broader lenses. About 5 percent of the rock consists of xenocrysts of fresh albite in somewhat broken crystals that not uncommonly have slightly resorbed edges. The xenoliths are mostly either of rocks possessing a fine-grained bostonitic texture or of rocks altered entirely to ore except for scattered small feldspar laths.

The possible stratigraphic importance of this rock is that it may represent a widespread and well-defined interval of rhyolitic outpouring. As such it would provide one of the few readily recognizable horizon markers in the older complex.

However, Smith and Hildebrand (1953, and written communication), in studying banded siliceous rocks south and southeast of the San Juan area, came to the conclusion that the fluidal banding in their rocks was secondary and was produced by the hydrothermal addition of silica in Eocene time. Yet, the fragments from the Frailes formation provide no evidence for doubting the primary nature of their flow banding, although it is possible that the quartzose streaks in this rock are deuteric, or even hydrothermal, as Smith and Hildebrand contend for the rocks east and west of Caguas. Even if this is so and even if one is not justified in hypothesizing a rhyolite interval as an islandwide stratigraphic marker, the El Minao road cut showed that this rock type already existed in Frailes time (Late Cretaceous) and refutes Smith and Hildebrand's (1953) conclusion that the alteration was of necessity Eocene in age.

The typical massive lapilli tuff of the Frailes formation is found in a deep road cut a few hundred yards to the south of the El Minao road cut just described. Here about 300 feet of massive wellcemęnted lapilli tuff is exposed, which consists of subangular to subrounded fragments, rarely exceeding $20 \mathrm{~mm}$ and averaging perhaps $5 \mathrm{~mm}$ in length, of dark aphanitic rocks embedded in a groundmass of dark, fine-grained material. White to light-pink zeolites are also common in the groundmass. The aphanitic texture of the lapilli is characteristic of these tuffs. The fresh rock is prevailingly dark greenish gray (5G 4/1) but many of the lapilli are shades of deep red and maroon. Where the rock is weathered it becomes varicolored, the lapilli fragments assuming various shades of green, purple, red, and brown. Although the tuff is dominantly massive there is a widely spaced rude stratification and some interbedded green siltstone and graywacke. Conspicuously though relatively sparsely imbedded in the breccia are angular masses up to 7 feet across of dark greenish-gray to dark maroon, thin-bedded shales (pl. $3 B$ ). The shale xenoliths tend to be concentrated in planes parallel to the rude bedding of the breccia. Many of the shale fragments are surrounded by thick rims of light-colored zeolites made up principally of laumontite.

Thin sections of the lapilli tuff show that the lapilli are mostly microcrystalline volcanic rocks whose textures range from pilotaxitic to bostonitic. In places these rocks are almost entirely opaque due to concentrations of magnetite and hematite. There are sparse broken crystals of sanidine, albite, and augite. The rock is very much altered. Zeolite minerals, chlorite, and very fine grained clayey (?) material makes up most of the matrix and replaces to varying degrees the lithic and crystal components.

Lapilli tuffs, identical to those described, crop out on the crest of the north-trending ridge about 0.7 miles southeast of Guaynabo, in a ridge 0.6 miles northwest of El Laberinto, and on Highway 175 northwest of Trujillo Alto. The coarse breccia in the El Minao road cut, however, is unique among the rocks examined in the San Juan area, both as to degree of coarseness and as to composition.

\section{DIscussion}

The occurrence of marine fossils in the Frailes formation shows that these rocks are at least partly of marine origin. The coarse breccia and the massive lapilli tuff are not incompatible with marine deposition. The coarse breccia may, for example, represent debris of submarine slides, and a somewhat similar origin for the lapilli tuff might account for the large angular blocks of shale embedded in it. Submarine sliding on a large scale is probably a normal ocurrence on the flanks of submarine volcanic cones, particularly during eruptions.

In several places in the San Juan area lapilli tuffs, somewhat similar in appearance to those in the 
Frailes formation, have been provisionally included as part of the Hato Puerco tuff. A broad area of massive lapilli tuff surrounded by Hato Puerco rocks crops out south of the Escuela Segunda Unidad de Cupey (these have not been shown on the accompanying geologic map owing to the reconnaissance nature of the mapping in this area). A somewhat similar rock appears at the western edge of the area of this report, near the headwaters of the Quebrada Camerones. The lapilli tuffs of the Frailes and Hato Puerco formations are similar in the size, shape, and aphanitic composition of the lapilli constituents. But in all outcrops of the possible lapilli tuffs of the Hato Puerco that were examined by the writer, the rocks are very much better cemented than the Frailes formation, tending to break across the lapilli grains rather than around them as characterizes unquestionably the lapilli tuff of the Frailes, and suggesting thereby the somewhat greater degree of regional metamorphism that is characteristic of the Hato Puerco tuff. There is, however, the possibility that the lapilli tuff mapped within the Hato Puerco is simply an example of unconformable overlap of the younger Frailes formation onto the flanks of the subsiding Caguas volcano, a process that has already been discussed (p. 9) and that is graphically expressed in figure 4 . Such an unconformable relationship might be preserved if the Frailes formation were concentrated in deep canyons or valleys (either submarine or subaerial) cut in the Hato Puerco tuff. The lapilli-tuff belt south of the Escuela Segunda Unidad de Cupey may therefore possibly be a Frailes outlier within the Hato Puerco tuff.

\section{IA MUDA IIMESTONE MEMBER}

Berkey (1915, p. 22) described the La Muda limestone as follows: "A rather heavy development of limestone in the vicinity of La Muda between Río Piedras and Caguas.... The rock is not prominently tuffaceous. ... It has in places a coarse fragmental structure almost completely obscured by healing and it is, as usual, attacked by cave development. . . ." Meyerhoff and Smith (1931, p. 283), on the other hand, state: "Berkey was not aware of the presence of two limestone formations in the vicinity of La Muda, but his brief description applies more fully to the calcareous beds situated one mile north of the village than to the shaly, or tuffaceous, strata situated to the south. The latter have been correlated with the Trujillo Alto limestone, and the name La Muda will therefore be used for the more northerly of the two calcareous beds."

A comparison of Meyerhoff and Smith's map of the Fajardo district and the map accompanying this report will show that the distribution of the limestones shown in the vicinity of La Muda, ${ }^{3}$ as well as along the Trujillo Alto section, are markedly different. The calcareous beds situated one mile north of the village of La Muda (Meyerhoff and Smith's La Muda limestone) is probably the local development of limestone that shown in this report about 0.6 miles north of the La Muda quarries and that is referred to the Trujillo Alto limestone (pl. 2). The limestone exposed, however, in the two quarries about $11 / 2$ miles southeast of the La Muda road fork and the limestone exposed to the southwest at El Laberinto are accurately described by Berkey, as to both location and lithology. There seems no reason therefore to redefine the name originally given to these rocks by Berkey, and in the present study the term is applied within the original guide lines established by him.

The La Muda limestone, which crops out in the quarries and their immediate vicinity, and to which Berkey apparently made reference in his original description, like almost all stratigraphic units in the San Juan area is somewhat variable in texture. The southeasternmost quarry expcses about 60 feet of thick-bedded, dark blue-gray to olive-gray, finegrained, rather pure limestone. Solution openings and veins of coarsely crystalline calcite are common. Under the hand lens the limestone is seen to be made up of rounded to subrounded grains, resembling oolites in size and shape, and rounded to spindle-shaped black argillaceous grains, generally 1 to $2 \mathrm{~mm}$ in diameter. In thin sections the rock is seen to consist of a dense aggregate of Foraminifera, Radiolaria, and small broken grains of calcareous algae. Similar thick-bedded limestone crops out in the surrounding areas, although textures vary from that of a skeletal limestone made up almost ex: clusively of finely comminuted shell fragments to a very fine grained limestone in which poorly preserved corals are barely discernible. Adjacent to a diabase dike the limestone has been bleached white and is finely crystalline. At El Laberinto, at the top of the hill that lies across the valley, west of the quarries, about 35 feet of the same limestone crops out on the road, and an estimated 60 feet of

- La Muda is an ill-defined roadside settlement that fringes the highway for a mile or more southeast of the intersection of Highways 1 and 20 . 
limestone is exposed in the quarry southeast of this little community. Here the rock is finely crystalline and the fragmental texture is not evident.

In the type area around La Muda, the La Muda limestone directly overlies the Tortugas andesite in the vicinity of El Laberinto but rests on what seems to be the Guaynabo formation (without the intervening andesite) on the hilltop about a mile to the northeast. Moreover, the limestone at El Laberinto clearly lenses out not far north of the village. It seems reasonable to suspect therefore that the La Muda limestone forms lenticular limestones in the lower part of the Frailes formation and is not a single bed or stratigraphic horizon. In the type section of the Frailes formation along the Trujillo Alto road, the two thin limestone beds found at the bend of Highway 175, due west of Trujillo Alto, are good examples of lenticular limestone in the lower Frailes and as such are designated La Muda limestone. They consist of an 18-inch bed and a 20-inch bed of somewhat arenaceous gray limestone separated by 13 feet of thin-bedded, lightgray sandstone. In this locality the limestone is separated from the Tortugas andesite by about 200 feet of noncarbonate rock of the Frailes formation. The variable nature of the lower contact of the Frailes formation is taken in part to result from the lenticular nature of the La Muda limestone and in part the highly discordant and overlapping nature of the transgressing Frailes formation onto the eroded surface of the older rocks.

\section{IEPROCOMIO LTMESTONE MEMBER}

The Leprocomio limestone member designates the more or less limey, well-bedded, cuesta-forming sediments in the upper part of the Frailes formation. These rocks crop out north of the bend of the Río Grande de Loíza at Trujillo Alto and are well exposed in the several quarries east and west of Highway 181. The outcrops of these rocks are close to Leprocomio (Insular leper hospital), after which the member is named.

The rock is characteristically a light- to mediumgray impure limestone and fine-grained calcareous tuff and, in general, shows few if any effects of solution weathering. There is some interbedded graywacke, and the proportion of limestone to graywacke varies rapidly along the strike. The thickness of limey beds in this member is very variable and apparently reaches its maximum development in the Trujillo Alto area where it is approximately 1,120 feet thick. Weathering of these impure lime- stones results in a leached rock in which the volume of the original rock is retained although its specific gravity is reduced. The typical weathered impure limestone is therefore generally a well-stratified, somewhat punky tuffaceous (or argillaceous) rock without much or any carbonate. Alteration of this type can be easily observed about $11 / 2$ miles northeast of Guaynabo $(188,780 \mathrm{~m}, 59,600 \mathrm{~m})$ where over 30 feet of limey beds exposed in a small quarry grade laterally within 100 feet into a completely nonlimey section of well-stratified, porous, tuffaceous rock.

The Leprocomio limestone member of the Frailes formation is apparently the limestone referred to by Meyerhoff and Smith (1931, p. 283) when they applied the term Trujillo Alto limestone. Their description of a tuffaceous limestone cropping out north of Trujillo Alto, which showed few effects of solution-weathering and that graded downward to noncalcareous beds agrees exactly with the characteristics of the Leprocomio member of the Frailes formation as herein defined. Their geological map of the Trujillo Alto road section, however, shows this limestone in aproximately the position of a higher limestone, the Trujillo Alto limestone as used in this report. The confusion concerning the term Trujillo Alto limestone will be discussed under the description of that formation.

$$
\text { AGE AND CORRELATION }
$$

The fossil faunas grouped under the Frailes formation are of late Late Cretaceous age according to J. B. Reeside, Jr., and that of locality 23582 has affinities with a Haitian fauna of Santonian (earlier Senonian) age. The Globator sp. from the La Muda limestone member (identified by C. Wythe Cooke) may be the same as "Echinoconus" antillensis Cotteau which has been attributed to the Cretaceous at Cienfuegas, Cuba. According to Cooke, the only known species of Globator in the United States is Globator parryi (Hall), which is abundant in the Georgetown limestone (Washita group) of Early Cretaceous age of Texas. The weight of faunal evidence, and particularly the ammonites, shows, however, that the Frailes formation is of late Late Cretaceous age. The list of fossils is given on the following page.

\section{MONACILLO FORMATION}

The Monacillo formation seems to be predominantly a continental deposit, ranging in texture from siltstone to conglomerate, and lying between the Frailes formation and the Trujillo Alto limestone. 
List of fossils from the Frailes formation

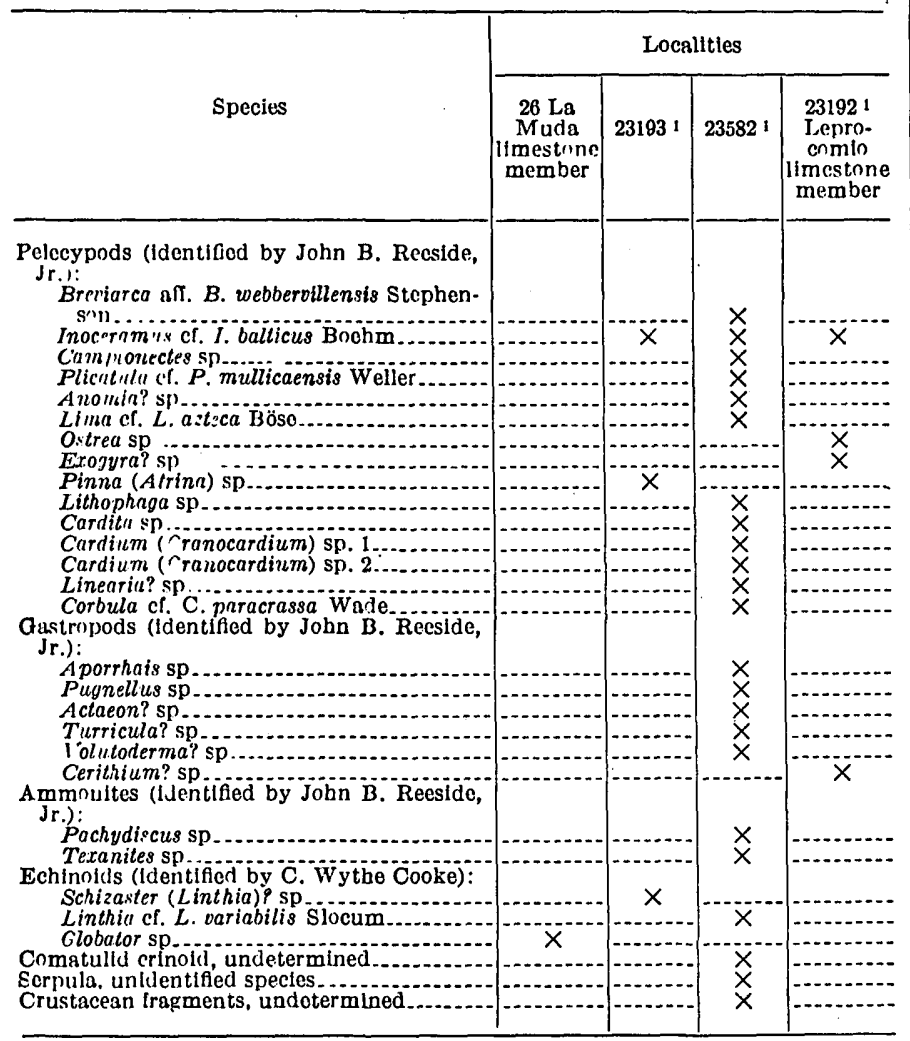

I Flve-digit numbers are U.S. Geological Survey localittes; other is author's locallty.

\section{Locality descriptions}

26 Aguas Buenas quadrangle; a hilltop 0.85 miles SE of La Muda road intersection $(188,785 \mathrm{~m}, 54,095 \mathrm{~m})$

23193 Aguas Buenas quadrangle; road cut, east side of Highway 1 at El Minao $(188,860 \mathrm{~m}, 58,263 \mathrm{~m})$.

23582 Aguas Buenas quadrangle; approximately 1.25 miles SE of La Muda, in low roat cut just $N$ of intersection of old Caguas road and Highway 173. (188,732 m, $53,480 \mathrm{~m}$ )

Trujillo Alto $(197,250 \mathrm{~m}, 58,880 \mathrm{~m})$.

The formation has been named from Barrio Monacillo, southwest of Río Piedras, where it crops out widely. The lower contact of the formation was not observed, but from its field relations the formation seems to be conformable with the underlying Frailes formation and the overlying Trujillo Alto limestone.

This is perhaps the most difficult stratigraphic unit to identify in the field due to its extreme heterogeneity of composition and its marked changes in thickness. In general, however, it can be said that it consists of fine to coarse clastic beds (as usual, made up of tuffaceous or volcanic material), showing some crossbedding, local unconformities, and channel filling. The beds are in many places maroon in color. At least one predominantly pyroclastic horizon, consisting of purple ash and lapilli tuff, has been noted $(187,820 \mathrm{~m}, 59,150 \mathrm{~m})$. The formation is probably nonmarine in origin.
On Highway 181, the Monacillo formation is relatively thin and is intruded by several diabase sills and plugs. The part of the formation that is exposed consists of obscurely bedded weathered yellow siltstone, which may represent an ash deposit, underlain by at least several feet of deep reddishmaroon conglomerate with subrounded to subangular pebbles as large as 2 inches, mostly of dark finegrained tuffaceous sandstone, ashy shales, and minor amounts of porphyry. There are interbedded fissile shales and obscurely bedded maroon medium-grained tuffaceous sandstone. Although a rather characteristic reddish or purplish coloration has been noticed in these beds at several places, it is not known how much of this along Highway 23 is a result of baking by the diabase intrusions.

The thickness of the Monacillo formation in the vicinity of the Trujillo Alto road has been scaled at about 900 feet. It is evidently very much thicker northeast of Guaynabo, although, due to the old alluvial soil cover in the area, a reliable estimate of thickness cannot be made.

Age and correlation-No fossils have been found in the Monacillo formation, but from fossils occuring in formations immediately above and below it there is no doubt that it is late Upper Cretaceous.

Berkey (1915, p. 21) described the Trujillo Alto limestone as follows:

\section{TRUJILLO ALTO LIMESTONE}

One [limestone member of the older complex] . . . has been observed only on the north side of the island in the vicinity north of Trujillo Alto and in the vicinity of Loiza. This is a very dense, fine bluish limestone made up wholly of fine microscopic organic growths. In some places it has a rough fragmental structure, but for the most part the rock is massive and the abundant organic content, largely algae, is its most striking characteristic. . . I It'is affected by solution developing caves at the Trujillo Alto locality in much the same manner as is the Arecibo formation, but this rock is a much more compact type and its content and structure relations are quite distinct. It was probably of reef origin also, but is associated intimately wih the upper shale members of the older series rather than with the Tertiary series.

Berkey thus clearly described the broad belt of limestone that crosses Highway 181 at Pueblo Seco and can be traced as a continuous outcrop to the east and to the west for several miles. The width of the outcrop at Pueblo Seco indicates that the formation may be as much as 900 feet thick here, which is by far its maximum thickness.

The Trujillo Alto limestone appears to overlie the Monacillo formation conformably in the vicinity of Highway 181, north of Trujillo Alto, although 
the contact was not seen. In this area and north of La Muda, the limestone is conformably overlain by fine-grained tuffaceous rocks and breccias of the Figuera volcanics. The Trujillo Alto limestone is very possibly absent in the basin between Guaynabo and Río Piedras, where there are indications that the Figuera volcanics are separated from the older rocks by an angular unconformity.

Several quarries in the vicinity of Pueblo Seco permit a clear picture to be formed of the characteristics of at least part of the total thickness of limestone in this area. The lower part of the formation, but not the base, is well exposed in the Umpierre quarry at the headwater of Quebrada Cepero $(194,700 \mathrm{~m}, 59,750 \mathrm{~m})$. It is a blue-gray to light-gray massive limestone containing echinoid fragments and lesser thicknesses of dark blue-gray to nearly black, medium- to thick-bedded, highly argillaceous limestone containing Turritella, thinshelled pelecypods, and fish scales. These beds are overlain by gray to light-gray, medium- to thickbedded pure limestone that consists principally of finely comminuted calcareous algae and shell(?) material. In places this rock has a brecciated structure and forms large massive reeflike lenses. Higher in the section, the quarry at Pueblo Seco exposes massive, dense, fine-grained limestone that is varied in color from dark blue to very light gray. In places there is a conspicuous mottling of light and dark, suggesting that a sort of bleaching may have affected the rock. The rock contains a vast amount of skeletal detritus, principally small foraminifera, calcareous algae, small corals, echnoids and echnoid fragments, bryozoan, small mollusks shells, (mostly gastropods, oysters, and rock borers, such as small Lithophaga), and miscellaneous shell detritus. The stylolites, which are rather common in this limestone, are generally lined with a thin, flexible tissue of sepiolite (palygorskite? $N=1.55$, positive elongation), associated with which are small seams of white, coarsely crystalline kaolinite. This is a very soluble and cavernous rock and its outcrops are generally fluted and deeply pitted. Formerly, a low "haystack" hill, similar in form to the larger karst features of the limestones of middle Tertiary age of the north coast, stood on the site of what is now the quarry at Pueblo Seco. It was this feature that probably inspired Berkey's comparison of the Pueblo Seco outcrop with the Arecibo formation (a formational name proposed by Berkey for all the middle Tertiary rocks of the north coast).
At the Pueblo Seco quarry the contact with the overlying Figuera volcanics is marked by about 20 feet of medium- to thin-bedded calcareous tuff, although the volcanics proper are not exposed in the quarry.

\section{AGE AND CORRELATION}

The Trujillo Alto limestone is rich in skeletal debris of many kinds, but it is not common to find fossils that are whole and sufficiently free of the dense limestone matrix to permit specific identification. Such indentifiable fossils as have been found by the writer indicate a late Late Cretaceous age. The following is a summary of the paleontologic findings on the Trujillo Alto limestone:

1. A collection from the black argillaceous limestone near the base of the formation in the Umpierre quarry was examined by John B. Reeside, Jr., who identified the following fossils, which he considered to be late Cretaceous:

Lucina? n. sp.

Venerid pelecypod

Turritella n. sp., related to T. tippana Conrad Cassiope n. sp.

Fish remains

2. The same carbonaceous facies from an outcrop about a mile to the west $(192,550 \mathrm{~m}, 60,580 \mathrm{~m})$ yielded a large number of poorly preserved ostracodes, "Cythereis" sp. and one or more smooth ostracode genera represented by internal casts. I. G. Sohn had suggested a probable Cretaceous age.

3. Foraminifera from the same rock that yielded the ostracodes were studied by Ruth Todd, who reported:

The sample contains very abundant specimens of Foraminifera, all of minute size for this group, the largest less than $0.3 \mathrm{~mm}$ in greatest dimension... Some of the species appear to be very finely arenaceous, but others may be silicified. The composition of the fauna (rich in individuals but poor in species), the abnormally small size of all the species present, and the dominance of two arenaceous genera commonly found in shallow and brackish water, suggest deposition in a brackish environment. Identification is very difficult, even as to genus. No age assignment can be given other than post-Paleozoic.
Halophragmoides spp.
Trochammina spp.
Nonionella? sp.
Angulogerina? sp. Gyroidina? sp. Cibicides? spp.

Bolivina? sp.

4. Very small echinoids, which weathered out of the massive limestone in the Pueblo Seco quarry in the upper part of the section, were identified iy C. Wythe Cooke as Magnosia? n. sp. This genus, 
known from the Jurassic (Bathonian) to the Upper Cretaceous (Cenomanian) of Europe and the circummediterranean countries, has not been noted before in the Western Hemisphere. The uncertainty, however, of the generic identification affects the usefulness of this fossil in dating the rock. The echinoid genus Cidaris occurs in abundance in the massive limestone, mostly as fragments.

5. A collection of corals from the same massive limestone in the Pueblo Seco quarry were studied by John W. Wells who judged them to be Late Cretaceous in age. The following species, all shallow water forms, were identified:

Elephantaria tottoni Wells

Actinacis sawkinsi Wells

Cladocora sp., cf. C. jamaicensis Vaughan

Monastrea sp., cf. M. schindewolfi Wells

Multicolumnastraea cyathiformis (Duncan)

Heliopora bennetti Wells

6. Well-preserved very small molluscan shells, which had weathered out of the massive limestone in the Pueblo Seco quarry and which are nondiagnostic insofar as separating the Upper Cretaceous from the Tertiary is concerned, consists of: Ostrea sp., Lithophaga sp., Pseudomalaxis? sp., Capulus? sp., and Cerithiopsis? sp. (the last three identified by Lloyd W. Stephenson).

Massive and thick-bedded limestone that is lithologically similar to the Trujillo Alto limestone crops out about $11 / 2$ miles west of the town of Loíza (206,$600 \mathrm{~m}, 59,900 \mathrm{~m})$. It underlies tuffaceous beds containing large Foraminifera of Paleocene or early Eocene age (Kaye, 1956). In a quarry at the outskirts of the town of Corozal, west of the San Juan area (Kaye, 1956), a massive, dense limestone, rich in skeletal debris and containing a coral fauna somewhat related to that of the Trujillo Alto limestone, is found as exotic blocks embedded in rocks judged to be also of early Tertiary age. The Trujillo Alto limestone is possibly the equivalent of these limestones. Its stratigraphic position may therefore be at the top of the Upper Cretaceous section and immediately below the Paleocene or lower Eocene. Indeed, the overlying Figuera volcanics of the San Juan area has much in common with the lower Tertiary rocks at Loíza and at Corozal.

\section{FIGUERA VOLCANICS}

The Figuera volcanics of the San Juan area consist of pyroclastic rocks of a highly variable thickness with lenticular calcareous beds and included blocks of older limestone (the Trujillo Alto? limestone) in its basal part. The volcanic rocks are charac- teristically hornblende andesite of a mauve to greenish color. The Figuera volcanics are thought to be Paleocene or early Eocene in age.

Meyerhoff and Smith (1931, p. 284) describe a belt of fine-grained andesitic flow rocks in the eastern part of the island, south of Fajardo, under the term Figuera formation. This volcanic horizon was placed stratigraphically between the Trujillo Alto limestone and the Fajardo shales, although these authors noted that no outcrop of Trujillo Alto limestone was seen in the vicinity of the Figuera volcanics. The volcanic rocks in the San Juan area are probably the equivalent of the east-coast rocks, if the stratigraphic position of the latter has been correctly established. The absence, however, of a common contact with the Trujillo Alto limestone at the type locality and the uncertainty that the Fajardo shales of Meyerhoff and Smith at Fajardo and those in the San Juan area are stratigraphically identical raise an element of uncertainty as to the identity of the two volcanic sequences.

In the vicinities of Pueblo Seco and La Muda, the Figuera volcanics conformably overlie the Trujillo Alto limestone and, in fact, incorporate limestone similar to the Trujillo Alto in their basal part. In the lowland between Guaynabo and Río Piedras however, they apparently are separated from the underlying rocks by an angular unconformity, for north of Guaynabo they rest on the Monacillo formation, whereas to the south they rest on the Frailes formation. The Figuera volcanics are overlain by the well-bedded tuffaceous sediments of the Fajardo formation.

The Figuera volcanics are thickest and best exposed over an area of several square miles south and east of the town of Guaynabo, where it is estimated that they include more than 3,000 feet of breccia and minor intercalations of flow rock. The local thickening possibly represents a vent deposit or cinder cone (fig. 4). The thickness of Figuera volcanics on the Trujillo Alto road (Highway 181) is estimated to be about 600 feet, although the formation is very incompletely exposed at this place. The basal limey beds are represented by about 20 feet of thinbedded nonfossiliferous calcareous tuff in the north ernmost part of the quarry of Pueblo Seco. These beds rest on massive Trujillo Alto limestone. The more characteristic pyroclastic rocks can be seen in the sides of the road leading to the new filtration plant of the Puerto Rico Aqueduct and Sewer Authority, where a breccia with angular fragments up to 2 feet across of dark hornblende porphyry and 
minor amounts of red chert is exposed. With the exception of the chert fragments, the rock is completely weathered to clay, retaining, however, its variations in color and texture and its individual crystal outlines. Similar weathered breccias crop out in the vicinity of the Penitenciaría and Manicomio and were encountered in drilling at the Sanatorio Insular, west of Río Piedras. The same rock is also exposed in a road cut about a mile west of the last point. From these few exposures it is inferred that the Figuera volcanics strike west across the northern edge of the upland basin and then sharply bend to the southwest and follow along the base of the cuesta north of Guaynabo.

The andesite of the Figuera volcanics is one of the most striking and distinctive petrographic types in the San Juan area and can readily be recognized megascopically by the presence of abundant hornblende phenocrysts and the speckled drab purplishgray to mauve groundmass. The typical mauve coloration is also imparted to the soil that develops on these rocks. In some places a blue-green color is prominent, resulting probably from the large amounts of fine-grained chloritic material it contains. The principal rock type is an albitized quartz-bearing hornblende andesite ("keratophyre" of some authors), occurring mostly as volcanic breccia, but also as flow rock, crystal tuff, and vitrophyre. The breccia typically consists of angular to subrounded fragments of fine-grained hornblende porphyry, which contains characteristically light colored albite phenocrysts embedded in a darker speckled matrix of somewhat fore fine grained hornblende andesite. Fine-grained white and pink laumontite, thomsonite, phillipsite, and apophyllite (identified petrographically) are common as veins, cavity fillings, and replacement of both feldspar phenocrysts and groundmass.

In hand specimen, the typical rock is a fine-grained porphyry with fluidly alined white feldspar laths up to $2 \mathrm{~mm}$ in length and shiny black hornblende crystals, generally up to $3 \mathrm{~mm}$ and rarely up to $5 \mathrm{~mm}$, embedded in an aphanitic grayish-purple $(5 P 4 / 2)$ to medium dark-gray $(N 4)$ groundmass. The white coloration of the feldspars apparently characterizes only albitized and zeolitized crystals. The relatively unaltered bytownite phenocrysts of the flow rock cropping out on the highway half a mile northeast of La Muda are dark in color. Under the microscope the rock is generally seen to consist of about 40 percent phenocrysts and 60 percent groundmass. Typically the feldspar phenocrysts are zoned and twinned albite, commonly with a certain amount of replacement by zeolite. The albite is probably secondary and some thin sections show relict fragments and zones of labradorite and bytownite within the essentially albite crystal. The relicts of the calcic feldspar also occur as somewhat broken outer zones about an albite core, though with some jagged embayments of albite. A few stubby crystals of adularia were noted in one thin section. The feldspar phenocrysts generally account for about 30 percent of the mass of the rock. Green hornblende euhedra make up as much as 12 percent of the rock mass and are of all sizes up to $3 \mathrm{~mm}$. Pigeonite (light green, nonpleochroic, $2 V$ about $30^{\circ}, Z \vee c=34^{\circ}$ ), in large crystals up to $3 \mathrm{~mm}$, is ubiquitous but always less abundant than hornblende and amounts to about 7 percent of the rock in some sections. Both hornblende and pigeonite are generally unaltered, though one thin section showed strong hematite rims about the hornblende. In a few samples there was an intimate association of hornblende and pigeonite, the two minerals making up what appeared to be halves of twinned crystals, which suggests the possibility that at least some of the hornblende was secondary after pyroxene. Rounded and embayed crystals of magnetite make up as much as 2 percent of the rock. Apatite is a very important and ubiquitous accessory mineral, occurring as long slender prisms in the groundmass and as poikilitic inclusions in the phenocrysts. The groundmass is generally a fine-grained xenomorphic granular aggregate, which from its refractive indices is probably albite, perhaps some orthoclase, and small nests and ill-defined streaks of xenomorphic granular quartz possessing strained extinction. A highly birefringent bright blue-green chlorite commonly occurs as an alteration of other minerals and as a vesicle filling. A yellow fibrous vesicle filling, which may be nontronite, is also common.

Exposed in the low hill that forms the right bank of the Río Guaynabo, half a mile northwest of Guaynabo, is an unusual association of glassy rocks within the Figuera volcanics. These appear to be interbedded welded tuffs (?) and vitrophyres. Rocks of this type have not been observed elsewhere in the Figuera volcanics of the area, though it is possible that they are extensively developed to the northeast. of this small hill, where the formation is mostly blanketed by thick soil.

The vitrophyre is dull brown, and its texture is pebbly on the weathered surface, reflective of a 
slightly perlitic structure. The fresh rock is a black pitchstone in which rather sparse small phenocrysts and lithic fragments are apparent to the naked eye. In thin section the rock is strongly banded with alternate dark-gray and light-pink bands (pl. $4 B$ ). The dark bands are glass $(n=1.515)$ densely packed with globulites and abundant oligoclaseandesine(?) microlites, fluidly alined. The light-pink bands are almost entirely devitrified glass and consist largely of crude rosette arrangements of small pinkish and greenish lath-shaped microlites of low birefringence, parallel extinction, and refractive indices less than balsam, and minute oligoclase-andesine laths. Scattered throughout both types of bands are phenocrysts of labradorite $\left(\mathrm{An}_{64}\right)$, generally in angular and broken fragments. These are varied in size up to $1 \mathrm{~mm}$ and make up an estimated 5 percent of the rock. The edges of the crystals show a certain amount of fusion and a few crystals are riddled with globules of glass. In addition to labradorite there are scattered and rather sparse augite crystals, generally less than $1 \mathrm{~mm}$ in size, that are spatially associated with the feldspar. Very small epidote spherulites(?) and fine apatite needles occur in the feldspar and augite.

A light brown aphanitic rock, sparsely speckled with fluidly alined cream-colored feldspar phenocrysts up to $2 \mathrm{~mm}$ in length and lithic fragments up to $5 \mathrm{~mm}$, interfingers with the vitrophyre. The relation of the two rocks is not clear. From the limited exposure it seems that the vitrophyre occurs as streaks several feet or more thick in the brown aphanitic rock. The latter rock has some of the characteristics of a welded tuff.

In thin section the welded tuff(?) is seen to consist of a glassy groundmass containing a dense population of small orange-red shardlike glass forms, which exhibit excellent flow alinement. The glass has an index of refraction of approximately 1.535, which according to George (1924) suggests a basaltic composition. The red coloration of the shardlike forms is imparted by globulites of reddish color, possibly hematite. Embedded in the glass are broken and fractured albite crystals up to $2 \mathrm{~mm}$ in length, which rather commonly show the effects of partial fusion about the edges. The albite phenocrysts are rather densely speckled by very small rosettes of a secondary mineral that, from its optical properties, may be a hydromica, or even talc.

The xenoliths in the welded tuff(?) vary from angular fragments to almost completely fused schlieren and represent several rock types, conspicuous among which are dark devitrified glasses, probably related to the vitrophyre already described, and rocks with a very fine trachytic texture.

ANALYTIC DATA

A chemical analysis of the dense flow rock that crops out on the southwest side of Highway 20, about 0.6 miles northwest of the La Muda road fork, is rather similar to the analysis of the Tortugas andesite (p. 15). The Figuera volcanics, however, are notably higher in $\mathrm{Al}_{2} \mathrm{O}_{3}$ and $\mathrm{CaO}$ than the former and have an unusually low $\mathrm{K}_{2} \mathrm{O}$ content. The high normative quartz is reflected in some thin sections by considerable xenomorphic granular quartz in the groundmass. The rock can be classified as a quartz andesite. The unusually low $\mathrm{K}_{2} \mathrm{O}$ content of this sample is not so readily explained, nor is the marked difference between the normative and modal plagioclase compositions (norm, $\mathrm{An}_{55} ;$ mode, $A \mathrm{An}_{70-80}$ ). The glassy groundmass of the rock is probably more siliceous and less calcic than the plagioclase phenocrysts.

A chemical analysis of the vitrophyre shows an intermediate composition. The composition, interestingly enough, is close to that of a Puerto Rican granodiorite collected by the writer from the central part of the island near Utuado, which in turn is close to the average composition of 56 basic granodiorites given by Johannsen $(1932$, p. 344$)$ and of 65 hornblende-biotite granodiorites given by Nockolds (1954). The vitrophyre has therefore the composition of a rhyodacite, the extrusive equivalent of a basic granodiorite.

The discrepancy between the modal and normative constituents of the vitrophyre is interesting. The absence of recognizable silica and the rather calcic composition of the plagioclase phenocrysts $\left(\mathrm{An}_{45}\right)$ points to a discordance between the composition of the preponderant glassy matrix and the phenocrysts. This suggests that (1) the glass consists of fused rock of intermediate composition that had contaminated the magma (fused wall rock), or (2) the glass is a late differentiate, whereas the phenocrysts date from an earlier, less evolved magmatic state. Since glass and cryptocrystalline material make up 90 percent of the mode, the composition of this material predominates in the bulk analysis. The normative composition of the glass is confirmed by the refractive index of the glass $(n=1.515)$ which indicates an $\mathrm{SiO}_{2}$ composition of about 65 percent (George, 1924). 
Chemical analyses and parameters of hornblende andesite, vitrophyre, and granodiorite from Puerto Rico, and of related rocks.

\begin{tabular}{|c|c|c|c|c|}
\hline$:$ & $\begin{array}{l}\text { Hornblende } \\
\text { andesite from } \\
\text { the Figuera } \\
\text { volcanics; s. side } \\
\text { Highway } 20,0.6 \\
\text { miles NW of La } \\
\text { Muda rood } \\
\text { intersection } \\
(187,280 \mathrm{~m}, \\
55,960 \mathrm{~m}) .\end{array}$ & $\begin{array}{l}\text { Vitrophyre from } \\
\text { the Figuera } \\
\text { volcanics: } 0.7 \text { mile } \\
\text { NW of Guaynabo } \\
\quad(185,630 \mathrm{~mm} \\
59,250 \mathrm{~m}) \\
\end{array}$ & $\begin{array}{l}\text { Granodiorite: } \\
\text { left abutment } \\
\text { Caonillas dam, } \\
\text { Puerto Rico } \\
(128,750 \mathrm{~m}, \\
49,200 \mathrm{~m}) .\end{array}$ & $\begin{array}{l}\text { A verage } \\
\text { compositlon of } \\
56 \text { more baste } \\
\text { granodiorites }\end{array}$ \\
\hline \multicolumn{5}{|l|}{ A. Chemical analyses } \\
\hline 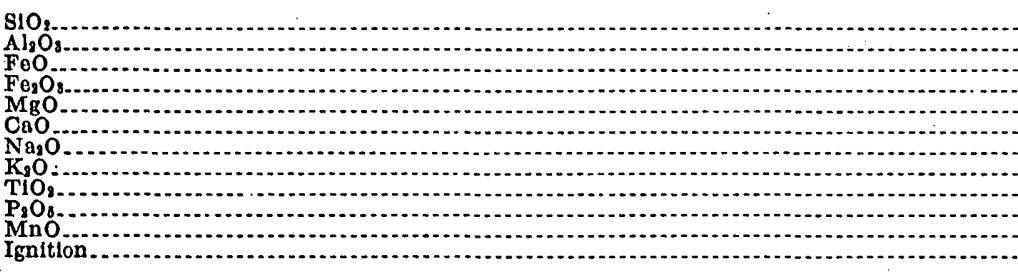 & $\begin{array}{r}85.6 \\
18.2 \\
3.2 \\
3.9 \\
2.7 \\
8.8 \\
-3.2 \\
.35 \\
.55 \\
.32 \\
.25 \\
82.7\end{array}$ & $\begin{array}{r}265.8 \\
14.8 \\
1.6 \\
1.8 \\
1.0 \\
3.8 \\
4.2 \\
2.0 \\
.66 \\
.20 \\
.12 \\
4.1\end{array}$ & $\begin{array}{r}65.9 \\
15.8 \\
1.6 \\
2.2 \\
1.8 \\
4.4 \\
3.9 \\
2.8 \\
.40 \\
.17 \\
.08 \\
9.84\end{array}$ & $\begin{array}{r}65.41 \\
15.72 \\
2.92 \\
1.57 \\
1.88 \\
4.08 \\
3.66 \\
2.99 \\
.58 \\
.17 \\
\left(\mathrm{H}_{8} \mathrm{O}\right) \quad .07 \\
\end{array}$ \\
\hline 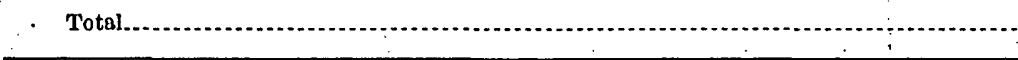 & 99.77 & 100.08 & 99.98 & 99.97 \\
\hline \multicolumn{5}{|l|}{ B. CIPW norms } \\
\hline 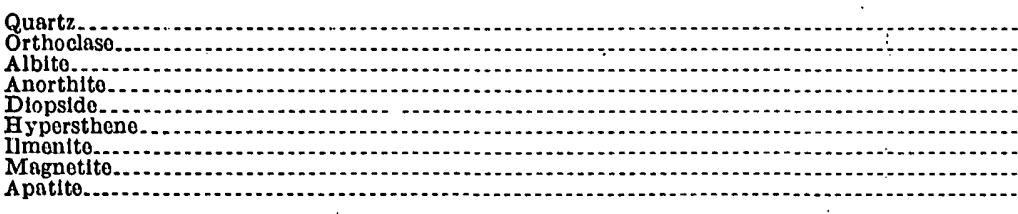 & $\begin{array}{r}14.11 \\
27.22 \\
27.25 \\
33.92 \\
6.21 \\
5.90 \\
1.06 \\
5.57 \\
.67\end{array}$ & $\begin{array}{r}24.74 \\
11.68 \\
35.63 \\
15.57 \\
2.62 \\
1.66 \\
1.37 \\
2.44 \\
\text { Trace }\end{array}$ & $\begin{array}{r}20.87 \\
16.68 \\
33.01 \\
17.24 \\
3.70 \\
3.55 \\
.76 \\
3.25 \\
\text { Trace }\end{array}$ & \\
\hline \multicolumn{5}{|l|}{ C. Mode } \\
\hline 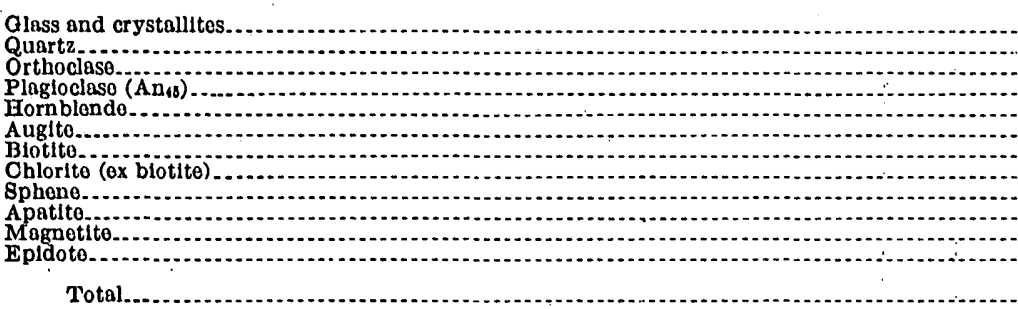 & $\frac{T r a c e}{100}$ & \begin{tabular}{c}
16 \\
23 \\
48 \\
8 \\
\hdashline Trace \\
3 \\
1 \\
Trace \\
Trace \\
1 \\
$100+$
\end{tabular} & & \\
\hline
\end{tabular}

Trom Johannsen (1932,, 2.2 , table 175).

includeal analyses by rapld method; analysts, Frank S. Borrls, Harry F. Phillips, and Katrine White, U. S. Geological Survey.

\section{AGE AND CORRELATION}

No diagnostic fossils have been found in the basal calcareous tuffs of the Figuera volcanics in the San Juan area, and the blocks of grey limestone embedded in the basal tuffs south and west of Guaynabo are probably fragments of the Trujillo Alto limestone. Nevertheless the Figuera volcanics are thought to be probably Paleocene or early Eocene in age. This age assignment is made on the basis of: fossils found in rocks both east and west of the map-: ped area (Kaye, 1956), which exhibit certain strati-: graphic similarities to the Figuera volcanics. One of: these localities is $81 / 2$ miles east of Río Piedras and about 1 mile west of the town of Loíza. Here a thick-bedded limestone, similar in appearance to the Trujillo Alto limestone, is overlain by bedded tuffs containing calcareous algae and late Paleocene or early Eocene large Foraminifera. The Foraminifera were-examined by W. Storrs Cole who identified Operculinoides bermudezi (D. K. Palmer), Discocyclina (Discocyclina) barkeri Vaughan and Cole, Discocyclina (Discocyclina) grimsdalei Vaughan and Cole, and Pseudophraginina (Athecocyclina) soladensis calebardensis Vaughan. The tuffs are overlain by amygdaloidal andesitic flow of aphanitic texture, which in turn is overlain by a relatively pure algal limestone, again richly studded with Paleocene or early Eocene large Foraminifera. This volcanic sequence may be the equivalent of the Figuera volcanics. Unfortunately no rocks stratigraphically higher than the upper limestone is exposed in the Loíza locality, nor are the lower Tertiary rocks directly traceable into the San Juan area. 
The second Paleocene locality is at Corozal, about 18 miles west of Río Piedras. The stratigraphic succession there is somewhat more complex than that at Loíza but consists essentially of a series of limestones, volcanic breccias and well-bedded tuffs. At the western edge of the town of Corozal there is a very coarse breccia, which is made up mostly of blocks of nearly white dense coralliferous limestone up to 20 feet across but also some blocks of andesitic rock embedded in a tuffaceous matrix. This breccia is possibly the equivalent of the basal part of the Figuera volcanics in the San Juan area, which contains large blocks of reworked Trujillo Alto limestone. Cropping out for a distance of at least a mile east and south of the quarry at Corozal are well-bedded tuffaceous rocks, locally calcareous, and lenticular, somewhat tuffaceous limestones. The latter have also yielded faunas that are very probably of Paleocene age (Kaye, 1956). These beds may grade into the hornblende andesites similar to the andesite of the Figuera volcanics, which crop out several miles southeast of Corozal (see quarry at $168,800 \mathrm{~m}, 53,500 \mathrm{~m}$ ). The field work necessary to prove this correlation has yet to be done.

\section{DISCUSSION}

If one is correct in correlating the Figuera volcanics with the fossiliferous lower Tertiary strata of Loíza and Corozal, then it appears that the Figuera volcanics represent a well-defined eruptive period that ushered in early Tertiary deposition. These eruptions may have been widespread throughout the region, if similar hornblende-quartz andesites found elsewhere in Puerto Rico and in Hispaniola (Woodring and others, 1924, p. 310) are contemporaneous.

In the San Juan area the pronounced local thickening southeast of Guaynabo suggests a cone that had formed about a local vent. Several or more vents might have existed in the region and pyroclastic debris from these eruptive centers might have formed this distinctive, though in places thin, stratigraphic marker.

The stratified tuffaceous limestone at the north end of the Pueblo Seco quarry and the foraminiferal tuff west of Loíza (Kaye, 1956) indicate that in places the basal part of the Figuera volcanics is marine. There is some question, however, whether or not the entire thickness of Figuera volcanics in the San Juan area represents marine deposition. Evidence that possibly argues against a marine environment for the entire thickness is the lack of any sign of marine sediments or bedding in the section other than at the base. A possible argument in favor, however, is the abundance of zeolites in these rocks. Park (1946), for example, discusses the significance of zeolites as an indication of saline interactions produced by the contact of marine waters on volcanic rock.

The nature and significance of the glassy rocks exposed in the small hill northwest of Guaynabo pose an interesting problem. The known distribution of these rocks is limited to the few acres of the hill itself, though it is possible they occur beneath the masking soil and alluvial cover to the north. The rocks consist of alternate streaks, or beds, of what appears to be a welded tuff and a black augite-labradorite vitrophyre, both showing very strong fluidal banding. A chemical analysis of a sample of the vitrophyre shows that it has the composition of a rhyodacite. The most important question raised by this rock is whether it is a product of the same eruptive cycle as that which produced the quartz-bearing hornblende andesites of the Figuera volcanics. It is noteworthy that almost all the essential mineralogic criteria of the Figuera volcanics-hornblende, pigeonite, and quartz-are missing in the vitrophyre.

The refractive index $(n=1.535)$ of the glass of the welded tuff(?) indicates that this rock has a bulk composition of basic andesite, or even basalt. The small glassy shardlike shapes, densely packed and fluidly alined, that make up much of this rock, are strongly suggestive of the glass shards of vitric tuffs. They lack, however, the sharp tricornered or arcuate shapes of normal glass shards but resemble rather, glass shards that have been very much softened, compacted, and thereby deformed. The glass of shard and matrix are alike except for the dark color of the shard forms, which is imparted by a dense conglomeration of red globulites-the same globulites that are found more sparsely distributed in the matrix glass. C. M. Gilbert (1938, pl. 3; figs. $3,6)$ figures several thin sections of the welded Bishop tuff in eastern California that resemble the Puerto Rican rock, except that in the latter the shard shapes are dark rather than light. The more deeply buried Bishop tuff is described by Gilbert as a dense, glassy rock in which the intense compression suffered by the pumiceous glass fragments made it possible for the glassy material to enter into the small embayments of resorbed quartz crystals (p. 1842). This phenomenon is duplicated in the Puerto Rican rocks where the shardlike forms squeeze into narrow corroded embayments and fractures of the albite xenocrysts. 
What is the origin of the welded tuff-vitrophyre association? The vitrophyre, which differs in mineralogy and chemical composition from the andesites of the Figuera volcanics, may possibly represent fused wall rock that was engulfed by the andesitic magma. Banded glass and pumice of different composition but resembling somewhat the Figuera volcanics in association have been described from the Mt. Katmai area of Alaska by Fenner (1950), among others. Fenner writes of large and small blocks in the incandescent tuff deposit of the Valley of Ten Thousand Smokes, consisting of bands of dark-colored basic glass $(n=1.520-1.540)$ and light-colored pumice and welded tuff. Similar banding also characterizes the dome of nearby Novarupta. Fenner considered the dark glass to be fused basic country rock that had been engulfed by the superheated rhyolitic lavas and retained as a somewhat immiscible phase in the acidic ejecta of the eruptions. The dark vitrophyre in the Figuera volcanics may by analogy represent such a fused wall rock, and its mineralogic composition may therefore reflect the composition of that rock rather than the composition of the Figuera lavas. But in the Puerto Rican association, unlike the Mt. Katmai occurrence, the fused wall rock appears to be the more silicic of the two components.

The question remains whether a welded tuff is an absolute criterion for the subaerial eruption of the Figuera volcanics-a question that has already been raised. Because so little is known about submarine volcanism, one is obliged to admit the possibility that welded tuffs can form beneath the sea. If they do, however, it seems most probable that they form very small deposits that are confined to the vicinity of the vent. High-temperature submarine eruptions may minimize the important cooling effect of the water environment, permitting the partial refusion of glassy ash. The extremely limited distribution of these rocks in the Figuera volcanics points to the possibility of such an interpretation.

\section{FAJARDO FORMATION}

Berkey (1919, p. 18) gave the name Fajardo shales to the blocky, well-bedded, ashy shales-or siltstones, as they are called in this report (see below) - that crop out in the vicinity of the town of Fajardo, in the northeastern corner of the island. Meyerhoff and Smith (1931) recognized the flows of the Figuera volcanics as forming the base of this formation in that area. Its upper limit they determined to be gradational with more coarse-grained beds, to which they applied the name San Diego formation. These authors included in the Fajardo shales all the blocky, well-bedded ashy siltstones in their district.

Although the ashy siltstone of the Fajardo formation at the type locality in the Fajardo area has not been traced to the San Juan area as a continuous outcrop, there is no denying that the lithologic similarity of the rocks in the two areas is strong. The name Fajardo has therefore been retained in this report for these rocks, but the descriptive term shale has been dropped because of the questionable appropriateness of the term to the prevalent lithology and because of the importance of other types of rock within the formation.

Most characteristic of the Fajardo formation is a relatively soft, very well bedded, light-colored, nonfissile aphanitic rock of a rather low density (pls. $7 B, 8)$. The lithologic term shale that was applied to these rocks by the New York Academy of Science authors is not quite appropriate because the rocks lack fissility. According to Twenhofel's classification (Twenhofel, 1937) they might more fittingly be called claystone, siltstone, or even bedded marine ash or ashy claystones, inasmuch as they probably consist largely of very fine grained volcanic ash now variously altered to clay. The term ashy siltstone is preferred, however, to a clay designation because to the touch the texture is definitely silty. The color is light yellow, light tan, white, pink, and various shades of red. The beds vary from 1 inch to 6 inches but are generally about 2 inches thick. Small undecipherable vermicular surface markings that suggest an organic origin are common on the bedding surfaces, but otherwise the beds are unfossiliferous. Thin intercalations, usually less than 1 inch thick, of light-gray to white kaolinitic clay are common between the individual siltstone beds. The rock is everywhere well jointed, and it breaks readily into rhomboidal-shaped flagstones and blocky fragments bounded by smooth joints and bedding planes. In thin sections the rock is seen to consist of a porous, fine-grained, clayey aggregate. James $P$. Owen reports (written communication) that X-ray and petrographic study of these rocks shows that they consist of kaolinite and quartz. Berkey (1915, p. 31) suggested that the pores were molds of Foraminifera whose calcareous tests had been leached by weathering. Despite the fact that the rock seems to be deeply weathered, it does not decompose readily to soft clay but retains its cohesive strength and form even when 
wet. This peculiarity probably accounts for the fact that in the San Juan area its outcrops generally form prominent topographic highs. Most of the Montes de Hatillo, south and east of Río Piedras, and the north- to northeast-trending ridge west of Guaynabo, for example, are cuestas of these rocks.

Besides the rather soft ashy siltstone there is also cream-colored to white thin-bedded chert and a siliceous siltstone. The latter is a rock that seems to possess qualities of both chert and ashy siltstone.

Intercalated with these ashy siltstones and cherts are other sedimentary rocks, ranging from tuffaceous limestone to conglomerate, and including bedded tuffs and volcanic breccias. These rocks are best developed in the Fajardo outcrop in the vicinity of Guaynabo and are relatively scarce in the Montes de Hatillo, east of Río Piedras. They are clearly more abundant in the southwestern part of the area, where they aggregate over half the thickness of the formation. In the following cross section of the Fajardo formation where it is exposed on the north side of the cut made by the Río Guaynabo through the cuesta ridge northwest of Guaynabo, the ratio of coarse-clastic and nonashy beds to ashy siltstone is very much greater than where the formation crops out in the Río Piedras area.

A little more than a mile south of the Río Guaynabo section an important thickness of massive to stratified purplish-gray tuff is found interbedded in the clastic beds of the upper part of the section. These are possibly the equivalent of Meyerhoff and Smith's San Diego formation. They are here included in the Fajardo formation because it seems evident that the typical ashy siltstone is only a facies and that the formation consists of a wide range of rock types forming an interfingering sequence.

The contact of the Fajardo formation with the underlying Figuera volcanics seems essentially conformable in the few places where it was seen, although in the side of the road about two-thirds mile southwest of Guaynabo a decided angularity exists between the flow lineation of the phenocrysts in a 5 -foot Figuera flow that is exposed there and the overlying ashy siltstone of the Fajardo formation. No formational unit of the older complex higher than the Fajardo formation has been recognized in the San Juan area. The maximum thickness of the formation was observed in the Trujillo Alto road traverse, where it is estimated that at least 3,000 feet of the Fajardo formation is exposed.
Section of part of the Fajardo formation exposed in north side of Rio Guaynabo valley, northwest of Guaynabo

Unit Description

Approximate
Thickness (feet)

1. Graywacke, gritty, well-jointed, thin- to mediumbedded; minor amounts of interbedded argillaceous sandstone and gray calcareous tuff and tuffaceous limestone. Graywacke is dark green when fresh, weathering to dark brown. Small pipes, resembling casts of worm tubes several inches long and one-half inch or less in diameter, of a dark green structureless material with a conchoidal fracture occur in this tuffaceous sandstone. The material was studied by Robert L. Smith, U. S. Geological Survey, who described it as a mineralogic anomaly. possessing the crystalline structure of celadonite but occurring in a manner more typical of glauconite. It may be crystalline glauconite or an intermediate link between typical glauconite and typical celadonite ...-. -

2. Siltstone, ashy, thin-bedded, light-colored; and

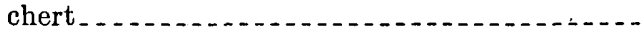

3. Conglomerate, fine, thin- to medium-bedded; and gray tuffaceous limestone, tuffaceous sandstone, and minor amounts of clay shale. -

4. Well-bedded red, yellow, and white ashy siltstone and siliceous siltstone with some crossbedding and ripple-marking. .......................

5. Interbedded, gritty, tuffaceous sandstone, fissile shale, and ashy siliceous siltstone. Siltstone makes up approximately 55 percent of total thickness..... . . . . . . . . . . .

6. Interbedded brownish-gray fissile arenaceous shale and greenish-gray fine-grained sandstone. . 2.

Total thickness of Fajardo formation exposed.

The Fajardo formation is considered to be marine, although no fossils have been found in it. The ashy siltstone probably accumulated from fine volcanic ash fallen directly into the sea and from detrital ash and land-derived sediment washed into the sea. The coarser grained and nonashy facies may have accumulated close to shore, possibly in a littoral environment. Following this line of reasoning, and considering the relative distribution of the sedimentary types, it appears that the parental land mass lay to the south and possibly west of the San Juan area. This agrees essentially with the position of the insular cone as deduced from the Hato Puerco tuff and other beds (fig. 4). Judging from the general absence of coarse-grained volcanic debris, volcanic activity during the deposition of the Fajardo sediments was either on a reduced scale or was relatively remote. Certainly the vents which ejected the 
Figuera volcanics were inactive in this area or else were emitting only fine ash. On the other hand, the tuff beds in the upper part of the formation reflect a renewal of explosive activities somewhere in the general neighborhood. Some of these pyroclastic deposits may even have accumulated subaerially and may thus be the landward continuation of the marine sediments of the formation.

Age.-No fossils have been found in the Fajardo formation. Because it overlies the Figuera volcanics it is judged to be late Paleocene or Eocene in age.

\section{INTRUSIVE IGNEOUS ROCKS}

\section{ALBITIZED BIOTITE GRANODIORITE PORPHYRY}

Cropping out in the southern part of the San Juan area is a body of porphyritic rock, of highly irregular shape, whose average composition is approximately that of a sodaclase granodiorite. However, it seems very probable that in these rocks, as in the volcanic rocks of the area, the albite is a replacement of a once calcic plagioclase. The rocks are therefore called albitized granodiorite porphyry in preference to A. Johannsen's (1939, p. 144, fig. 106) term "sodaclase-granodiorite," which, to the writer, does not denote clearly enough, except by implication, the secondary nature of the albite.

Megascopically, the granodiorite porphyry generally consists of white to pink feldspar phenocrysts, 3 to $5 \mathrm{~mm}$ in length, abundant to sparse quartz crystals ranging up to $5 \mathrm{~mm}$ in length; and small, commonly bleached biotite flakes in an aphanitic bluishto greenish-gray groundmass that makes up from 45 to 65 percent of the rock mass. The microcrystalline texture of the groundmass points to a hypabyssal origin for these rocks. Facies that are finer grained and coarser grained than the typical rock occur.

Microscopically the feldspar phenocrysts are seen to be mostly albite, in an advanced state of alteration to coarsely crystalline carbonate, sericite, and lesser amounts of chlorite. Some thin sections show orthoclase as well, but this mineral is never as abundant as albite. Some albite contains small relict patches of a calcic plagioclase; unfortunately the composition of these relicts could not be determined by the normal optical methods employed. The size and relative abundance of quartz phenocrysts is highly variable. In the coarse-grained rock that crops out at the south margin and near the southwest corner of the mapped area, quartz phenocrysts make up about 20 percent of the rock, but in other places they form less than 1 percent. The quartz crystals are generally somewhat rounded and em- bayed, and they occur as single individuals and as groups of twins. Extinction is sharp. Some thin sections show a slight continuous growth of quartz from the phenocryst into the groundmass, and others show a thin aureole of minute epidote spherulites that form a halo at the edge of the quartz. The biotite, which makes up from 8 to 10 percent of the rocks, is always colorless in thin section; it is partly to entirely replaced by chlorite. In some thin sections the biotite crystals are bent and much shredded at the terminations. Noted in one thin section were sparse phenocrysts of chlorite, which, judging from their outline, were originally an amphibole or pyroxene. The groundmass of the granodiorite porphyry is a microgranular aggregate of quartz and orthoclase-in which the percentage of quartz ranges from an estimated maximum of 80 percent to less than 20 percent-and very small scales of colorless mica in a sparse felted arrangement. Accessory minerals include rather common apatite up to $0.2 \mathrm{~mm}$ in length, sphene, and rare tourmaline in slender prisms. The secondary minerals chlorite (penninite), sericite, carbonate, and epidote were common in all thin sections studied.

The granodiorite porphyry is generally deeply weathered, and relatively fresh rock can be found only in stream beds. It weathers to a light gray to nearly white residual soil, characteristically rich in small mica flakes. The very light color of the soil and the presence of mica are of distinct aid in tracing the outcrop of this rock in the field. The weathered rock is easily eroded and the outcrops of granodiorite porphyry are commonly marked by topographic lows.

The outcrop pattern of the granodiorite porphyry indicates that the rock belongs to a rather large subjacent body of which only the upper part has been exposed. The deeper valleys show that the intrusive mass is discordant and widens at depth. Moreover, the contacts are generally sharp and show negligible metamorphic effects. The variations in texture and composition of the granodiorite porphyry suggest that it was formed under rather varied conditions of cooling, like that which might occur in the cupolas and uppermost reaches of a large subjacent magma body. These factors point to the possibility that the San Juan and adjoining areas are underlain by a broad intrusive mass, which has been unroofed by erosion in only a few places and which has a varied though predominately granodiorite-porphyry composition in its upper parts. This igneous body may well be related to, if not connected with, the batho- 
lith that crops out in southeastern Puerto Rico, which has been described by Fettke (1924).

\section{AUGITE ANDESITE PORPHYRY}

Under this heading are included coarsely porphyritic dark rocks that occur as both tabular and irregular-shaped bodies, which, in places, give evidence of assimilation of their wall rocks. These rocks are considered to be hypabyssal intrusives, although, as will be explained later, there is a problem of distinguishing some of these rocks from the volcanic Tortugas andesite. The rocks generally have a dark gray $(N 3)$ aphanitic groundmass with randomly oriented plagioclase phenocrysts up to $8 \mathrm{~mm}$ in length and sparse augite crystals of about the same size. In places the groundmass is a lighter gray with dark greenish-gray specks consisting of spherulites of celadonite and (or) chlorite.

The largest body of augite andesite porphyry is in the southern part of the mapped area. Here the outcrop is marked by boulder-littered slopes and an especially red soil. Only several dikes of this rock have been shown on the geologic map, but narrow tabular intrusions are undoubtedly more common than these few examples indicate. Augite andesite porphyry also occurs as sills at several stratigraphic levels. One of these is in what is probably the contact of the Guaynabo and Frailes formation, that is to say, the horizon of the Tortugas andesite. The large quarry at Trujillo Alto is thought to be in a local thickening of such a sill. Although the Tortugas andesite is not always present in the section, its stratigraphic position is in several places marked by coarsely porphyritic andesites that are thought to be of intrusive origin. The reasons for considering these rocks to be intrusive rather than the extrusive Tortugas andesite is primarily (1) the coarseness of grain size in comparison with the typical Tortugas andesite, (2) the localization of the largest phenocrysts in the upper part whereas flow rock would probably have a chilled upper contact, (3) evidences of wall-rock assimilation, and (4) textural and compositional peculiarities, which will be described below.

The typical augite andesite porphyry contains about 70 percent of dark-gray to dark blue-gray groundmass. The groundmass has a hyalopilitic texture consisting of a felt of minute oligoclase-andesine laths (in places, skeletal crystals with swallowtail terminations) and narrow prisms of augite in rosette arrangement in a mesostasis of devitrified brown glass. The glass is rich in crystallites, spherulites, and curly fibers of a colorless mineral (low birefringence and an index of refraction slightly above Canada balsam) and some green chlorite. In addition, there are many amygdule-shaped bodies of a fibrous, light brownish-yellow, clay mineral (possibly chlorite or celadonite) in spherulitic or concretionary structure. Calcite and scattered grains of clinozoisite also occur in the groundmass. The entire cryptocrystalline mesostasis, and particularly the chlorite and celadonite, is densely sprinkled with minute grains of high birefringence and relief (epidote and rutile?).

The phenocrysts consist of calcic labradorite (generally $A n_{67}$ ), making up about 20 percent of the rock; fresh augite, making up about 2 percent of the rock; and a pyroxene entirely replaced by chlorite. In a few thin sections the plagioclase has been albitized.

There are strong indications of a certain amount of wall-rock assimilation. In several places the contact of the sedimentary country rock and the andesite is gradational over a distance of 50 or more feet and is first marked by the appearance of scarce, small plagioclase phenocrysts in what seems to be the country rock. These phenocrysts become more abundant as the andesite is approached until the typical andesite porphyry is developed. Fragments and short veinlike masses of microcrystalline calcite resembling normal unmetamorphosed limestone were noted in the andesite porphyry at the quarry at the edge of Trujillo Alto and in the small oval area south of Río Piedras. It is possible that these are unassimilated relicts of limestone country rock, although, if so, their apparent lack of recrystallization is unusual under the circumstances.

Where the sill of andesite porphyry crosses the new Río Piedras-Caguas highway, 2 miles south of Río Piedras, iriduration of the underlying sandstone and shale can be seen and large boulders of comb quartz, up to 12 inches across, are found on the lower slopes of the small hill just west of the highway at this point.

\section{DIABASE}

Diabase dikes, sills, and irregular pipelike bodies occur throughout the section of older complex rocks. Not uncommonly their outcrops are marked by low hills with large telltale residual boulders on the surface. The rocks range in texture from coarsegrained, containing plagioclase laths $5 \mathrm{~mm}$ or more in length, to fine-grained diabase, in which the plagioclase laths are about $0.7 \mathrm{~mm}$ in length. The presence of varied amounts of quartz is common, al- 


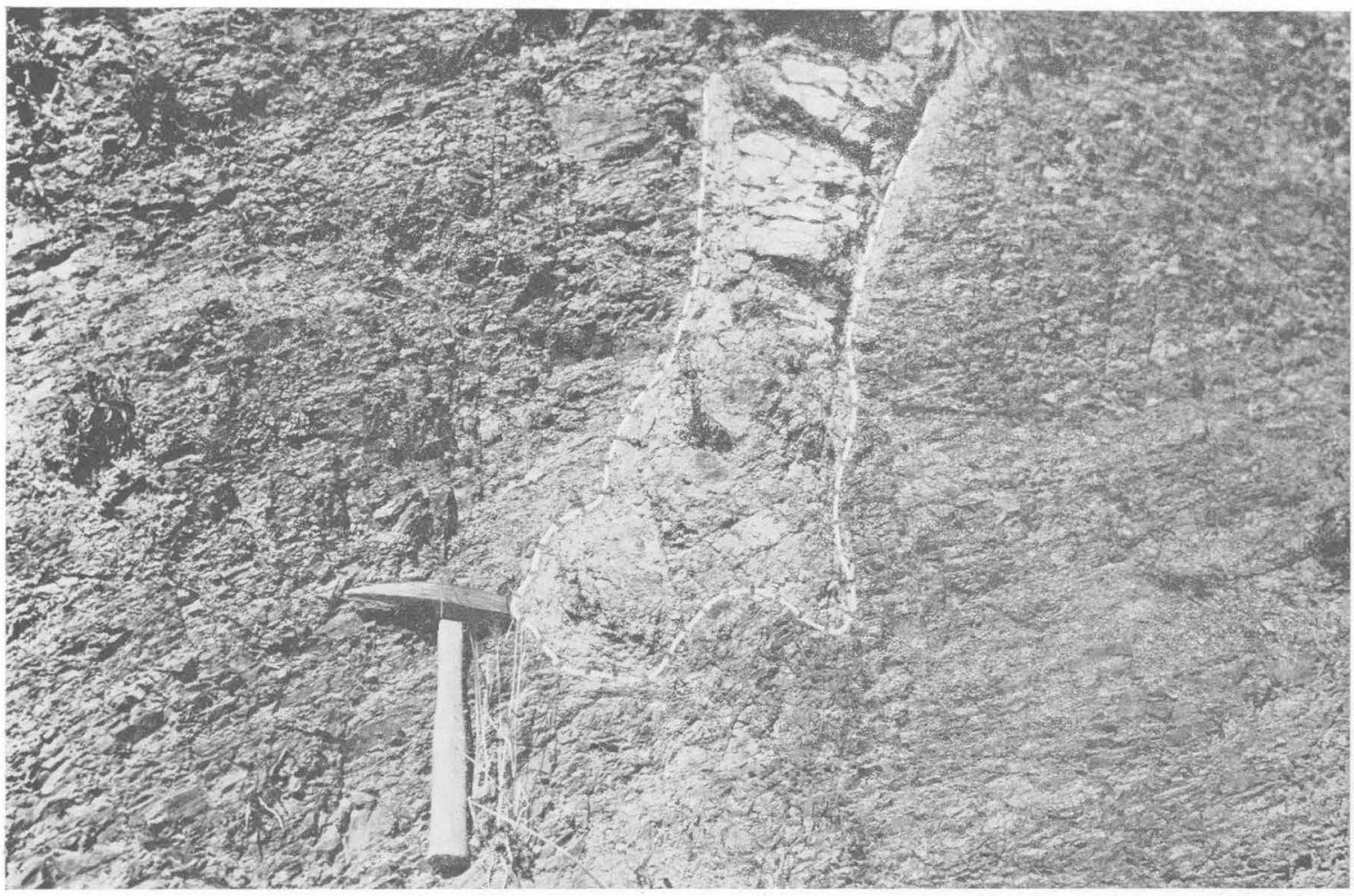

A. DRUMSTICK DIKE IN THIN-BEDDED ASHY SILTSTONE

Note lack of bedding distortion that would have been expected if dike had been emplaced by dilation

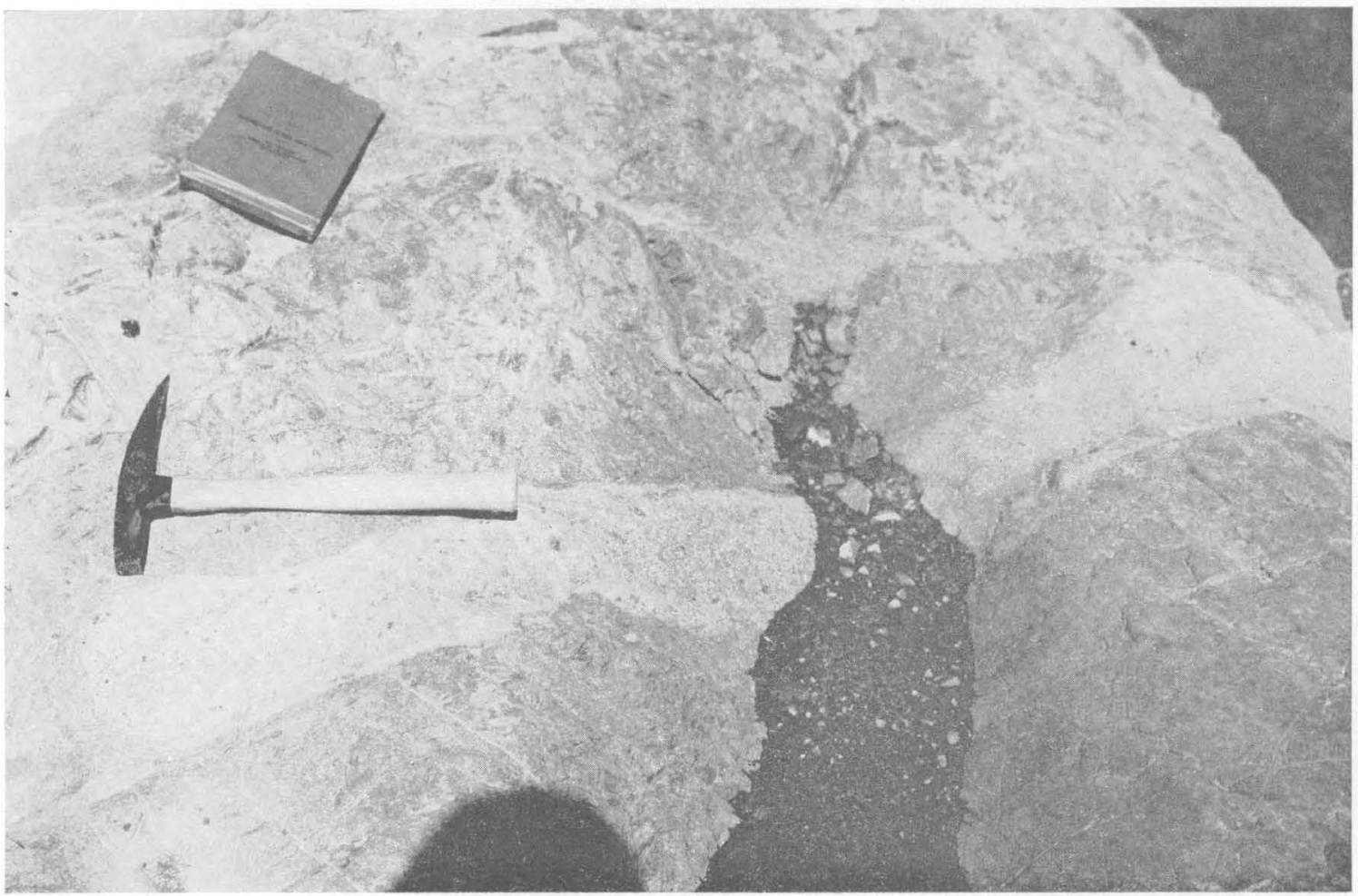

B. DRUMSTICK DIKE (LIGHT) IN ACTINOLITIC METAANDESITE; BED OF THE Río GRANDE DE LoÍZA, AT DAMSITE 


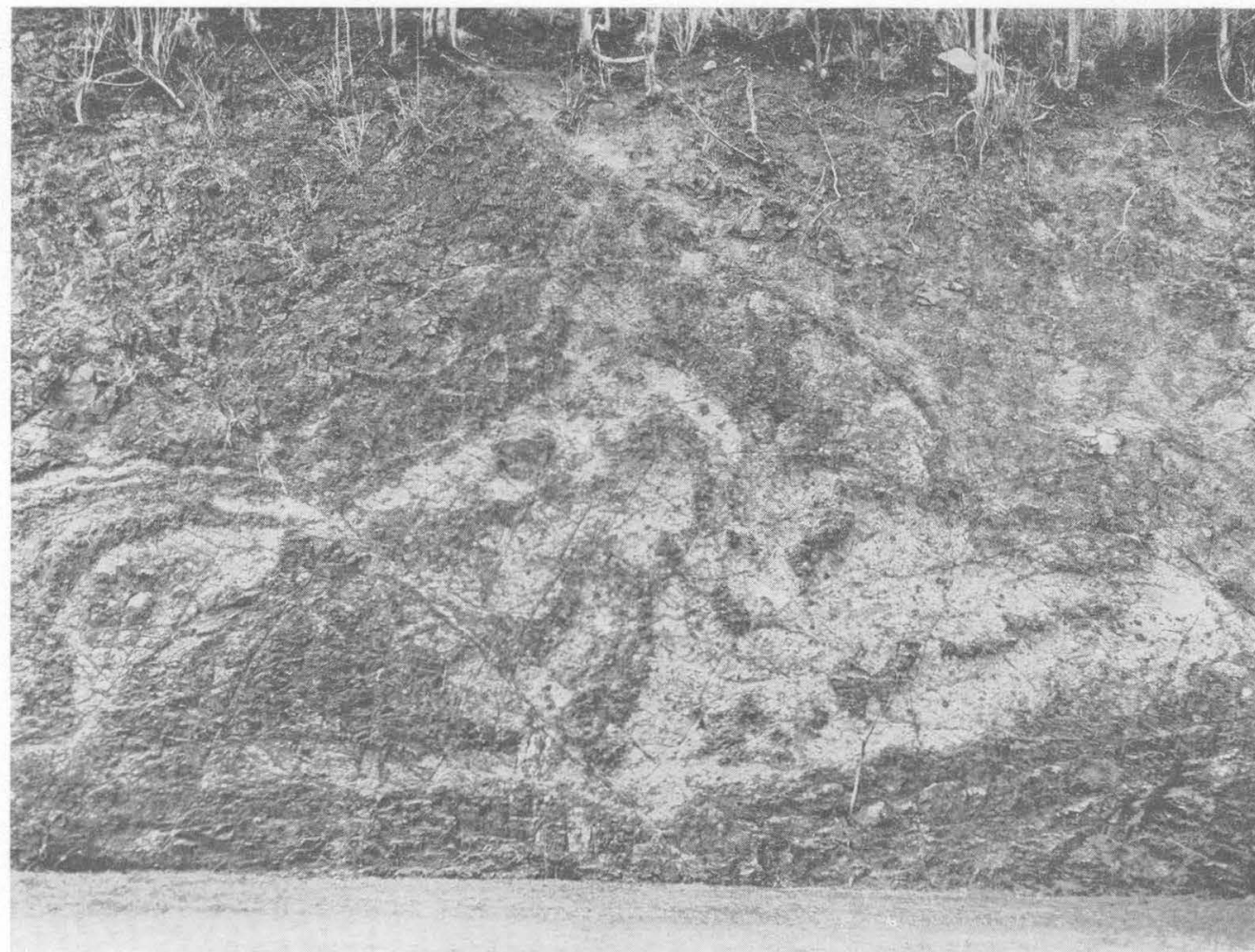

A. IRREGULAR-SHAPED REPLACEMENT OF THIN-BEDDED ASHY SILTSTONE BY ANDESITE PORPHYRY (LIGHT COLOR); COAMO QUADRANGLE, ON HIGHWAY 14

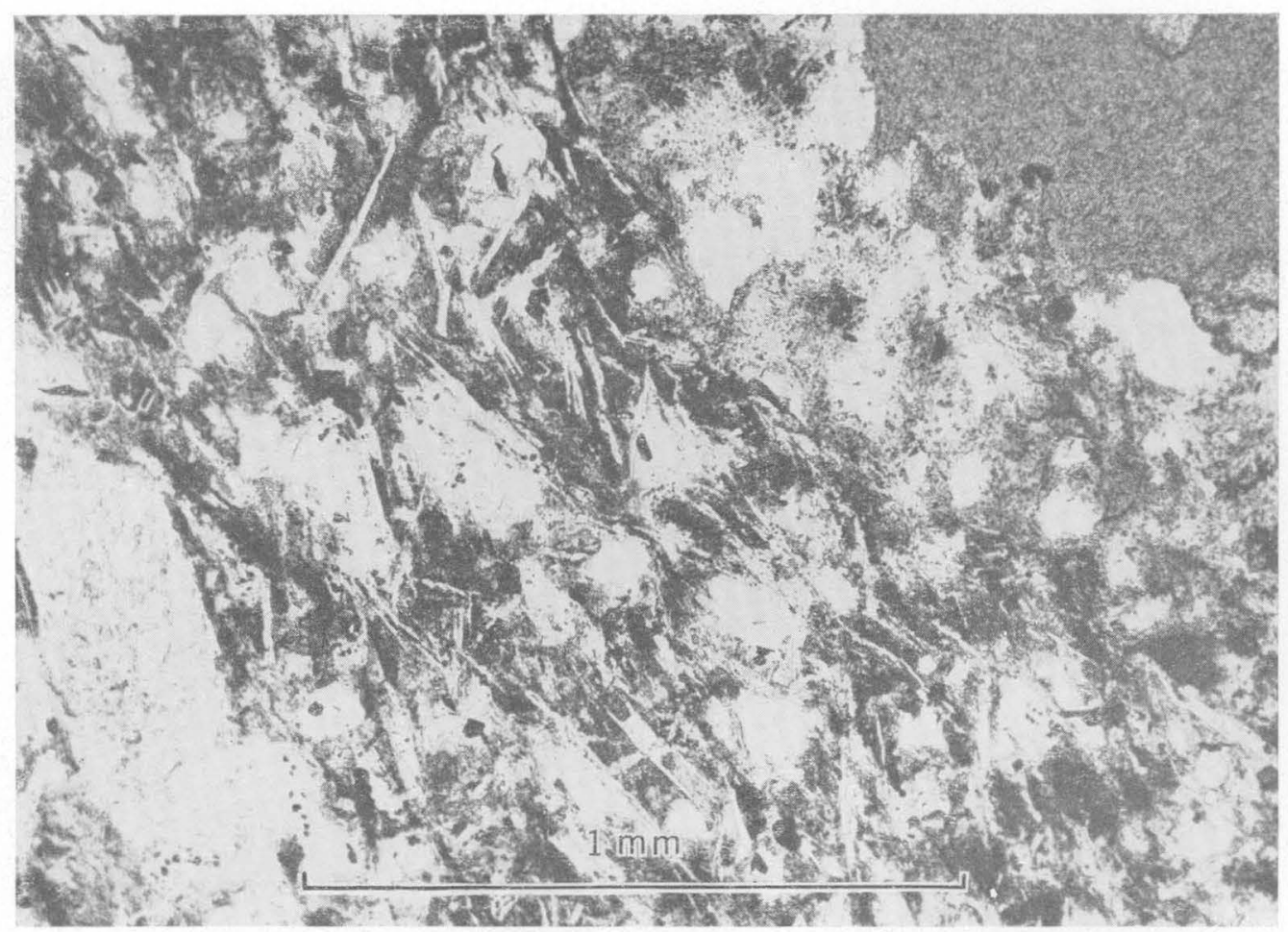

B. METAGRAYWACKE; FAJARDO QUADRANGLE, NORTH SIDE OF RÍO DEMAJAGUA VALLEY

Relict quartz (clear) with secondary swallow-tailed albite laths; albite porphyroblast in lower left and part of a chlorite. epidote "amygdule" in upper right. Magnification $69.9 \times$, plane polarized light 
though some thin sections show none at all. Besides the usual augite there is some biotite and always considerable amounts of interstitial chlorite, which may be largely secondary after biotite. The feldspar is commonly albitized but in places still retains its labradorite composition. The diabases are generally extensively altered to chlorite, clinozoisite, zeolites, and carbonate.

AGE OF INTRUSIVE ROCKS

The oldest of the three intrusive rock types recognized in the San Juan area is probably the andesite porphyry. This rock has not been seen cutting other intrusive rocks. The last of the three rock types to be intruded is the diabase, for dikes and plugs of this rock are found cutting the granodiorite porphyry. An andesite porphyry dike cuts the Figuera volcanics a little less than a mile east of La Muda. Thin dikes of the same rock have been seen cutting the Fajardo ashy siltstone in the Montes de Hatillo. For this reason all three rock types are thought to postdate the entire sedimentary and volcanic section of the San Juan area, and their date of emplacement may therefore be late Paleocene or Eocene. This does not eliminate, however, the possibility that the andesite porphyry may have been intruded over a long time interval, starting perhaps in the Cretaceous. The intrusion of the granodiorite porphyry, from the outcrop pattern in the area east of La Muda, appears to have followed major faulting. The lack of strain shadows in the extinction of the quartz of the granodiorite porphyry and their presence in the quartz of the Figuera volcanics is another possible indication that major structural deformations preceded the emplacement of the former rock. This interpretation, however, requires further study.

\section{METAMORPHISM AND ALBITIZATION} REGIONAL METAMORPHISM

Megascopically, none of the rocks of the San Juan area are metamorphic in aspect. All of them preserve intact the original structures and textures of igneous and sedimentary rocks. This is, moreover, true of most older complex rocks in Puerto Rico ${ }^{4}$ and is in contrast with the adjoining island of Hispaniola, on which Koschmann and Gordon (1950) and others have studied well-developed, widespread metamorphism of a regional type. However, the Puerto Rican older complex rocks, and those in the

\footnotetext{
- The writer has seen fine- to coarse-grained schists at several localities in Puerto Rico. All of these, however, gave evidence of being localized in zones of contact metamorphism or major faulting.
}

San Juan area in particular, show persistent suites of secondary minerals, chiefly chlorite, epidote, and albite, and in places actinolitic hornblende (Hato Puerco tuff), which probably indicates metamorphic changes on a regional. scale. If this is so, however, the large amount of original mineral constituents retained in the older complex rocks can be considered indicative of a very incomplete and lowgrade adjustment.

Chlorite (very commonly penninite) is almost ubiquitous; and epidote, clinozoisite, and calcite can be found in almost all thin sections regardless of rock type. Feldspars are commonly albitized. Secondary amphibole, generally in the form of fine actinolite, is largely confined in the San Juan area to the Hato Puerco tuff. All these minerals are typical of Eskola's (1939) green-schist facies, which is formed by the lowest grade of regional metamorphism. It is not certain, however, just how much these minerals owe their presence in the Puerto Rican rocks to metasomatism or to regionally elevated pressure and temperature.

There is some basis for thinking that the rocks have responded more to the introduction of new constituents and perhaps to heat than they have to pressure. There is a lack of preferred orientation to the platy secondary minerals, such as the chlorites. No study was made of quartz orientation, but some primary quartz has sharp extinction indicating a lack of strain. Both factors suggest that large stresses did not markedly effect the rocks, an impression that is substantiated by the general moderate deformation by folding that is exhibited by these rocks.

\section{ALBITIZATION}

One of the most persistent and characteristic of the mineralogic changes of older complex rocks is the alteration of soda-lime plagioclase to albite. Albite occurs in rocks of sedimentary, volcanic, and intrusive origin; and it is characteristically present in all rocks that show advanced alteration to secondary minerals. Thus albitized rocks are generally high in sericite, chlorite, calcite, and epidote.

Albite is commonly characterized in thin sections by incomplete extinction between crossed nicols. This effect probably arises either from a general disruption of the plagioclase space lattice by discordant or disarranged molecules, or from the general spatial disarray produced by the removal or regrouping of ionic components of the anorthite molecule during the process of albitization. 
The presence of relict soda-lime feldspar in some of the albite, as well as unaltered crystals of soda-lime plagioclase in rocks that are closely related to the albite-bearing rocks points to the secondary nature of most, if not all, of the albite and suggests the importance of local factors-such as relative permeability of the rocks to diffusibles-to the process of alteration. The importance of permeability seems especially indicated by the fact that dense, glassy rocks are somewhat less albitized than holocrystalline rocks. This suggests that the reagents responsible for albitization were more readily able to move along the wide channelways of crystal interfaces and along the cleavage partings in crystal space lattices than through the randomly distributed and probably discontinuous inter-ionic spaces of a glass.

The importance of metasomatism in the formation of a typical spilite-keratophyre association has been discussed by Turner and Verhoogen (1951, $p$. 201-212). These authors have emphasized the importance of marine connate waters within a thick sedimentary prism to the process of regional soda enrichment. Part of the sedimentary section of the San Juan area, however, is probably nonmarine in origin, and the Hato Puerco basement rocks constitute a volcanic cone, part of which probably accumulated subaerially. Moreover, albitization has affected the granodiorite porphyry which, it will be recalled, may form part of a larger subjacent igneous body. These facts suggest that soda from marine waters entrapped in the sediments was not entirely responsible for the albitization of the older complex rocks. At least some of the albitization may be due to magmatic emanations rich in soda, and some of it may be due to the selective removal of the anorthite molecule from the plagioclase space lattice and its replacement by calcite, sericite, and chlorite. The latter would appear possible on theoretical grounds and should be considered in a detailed study of an albitized province such as that of the older complex of Puerto Rico.

\section{ASSIMILATION, METASOMATISM, AND CONTACT METAMORPHISM}

The frequency with which one sees igneous textures blended into nonigneous rocks; the presence of fragments of country rock, particularly limestone, in the andesite porphyries; the structural relation of small intrusions and country rock; and the varied revelations of the microscope-all point to the probability that a large amount of sedimentary country rock has been transformed by one process or another into rocks that appear to be igneous.
Whether this is a matter of assimilation or of metasomatism (andesitization?), as the terms are currently defined, remains to be investigated.

Basic dikes and odd-shaped intrusions, the mechanics of whose emplacement seems difficult to explain other than by assimilation or metasomatism, have been noted at several localities in Puerto Rico. One of the most frequently encountered forms of these intrusions is the drumstick dike, a term used here to designate a dike with an abrupt, rounded, and not uncommonly slightly bulbous termination (pl. $5 A, 5 B)$. Plate $5 A$ is a typical example of one of these dikes and shows the lack of distortion of the thin-bedded ashy siltstones about the margins of the dike. Noble (1952, p. 35-36) has described drumstick dikes in the Homestake mine, South Dakota, and has shown that there the structure of the surrounding wall rock has been deformed to accommodate the intrusion. There is no structural evidence, however, that the spaces occupied by the several Puerto Rican dikes studied were due to dilation of the walls, either forcibly or otherwise. The only apparent means for the emplacement of this and similar dikes is by filling of a preexisting cavity or by the replacement of the wall rock, that is, by assimilation, metasomatism, or "granitization," depending on one's preference among these controversial terms.

In addition to drumstick dikes, several exposures of well-bedded rock were seen, in which andesite bodies of highly irregular shape graded into the normal wall rock or showed negligible wall-rock distortion, and where palimpsests of the bedding were apparent in the andesite. One of the best of these (pl. $6 A$ ) occurs outside the San Juan map area, on the Aibonito-Coamo road (Highway 14), about 41/2 miles as the crow flies northeast of Coamo $(167,070$ $\mathrm{m}, 30,650 \mathrm{~m})$. The country rock here is a thinbedded, tuffaceous sandstone and ashy siltstone. The invading rock is a hornblende porphyry (probably andesitic) with an aphanitic groundmass. Several drumstick dikes occur and large irregular masses of porphyry grade into the country rock. The porphyry seems to replace the tuffaceous siltstone selectivity along bedding planes, and palimpsests of siltstone strata occur in position within the porphyry. No displacement of bedding is apparent around the margins of this body.

An interesting example of contact(?) metamorphic texture is a dark blue-gray hornfels with conspicuous amygdules that crops out on the north side of the valley of the Río Demajagua about 3 miles south of Fajardo, outside the San Juan map 
area. Prominent quartz and calcite amygdules litter the outcrop area. In the hand specimen, this rock resembles a dense aphanitic flow rock, and apparently it falls within the area mapped as the Figuera formation by Meyerhoff and Smith (1931). Microscopic examination, however, shows that it is probably an altered tuffaceous sandstone or graywacke.

In thin section (pl. 6B) the rock is seen to consist of scattered subrounded quartz grains, up to about $0.15 \mathrm{~mm}$ in size and showing, some continuous growth and strained extinction, and a groundmass that is made up of a combination of quartz and feldspar with much ore dust, minute patches of chlorite, and some very fine grained epidote. Slender, slightly bent albite laths, generally with swallow-tailed terminations, occur in a sparse felted arrangement between the quartz grains. There are a few scattered albite porphyroblasts about $0.5 \mathrm{~mm}$ in length. Sillimanite needles occur sparsely and seem to favor the quartz. Rods of ilmenite are rather common. The amygdules are of two types-those completely filled with strained quartz in fine to coarse grains, and those completely filled with fine-grained chlorite and some epidote.

The scattered quartz grains are the most obvious mineralogic relicts of the original graywacke. The alteration of some of the nonquartzose components of the original rock to albite laths in a felted arrangement seems particularly interesting. This texture suggests that similar contact metamorphism of a tuffaceous sandstone or graywacke with somewhat less quartz might conceivably produce a typical pilotaxitic or even diabasic texture that could be confused in thin section with an igneous rock. Whether or not this type of alteration produced any of the andesite porphyries and albitized diabases noted in the San Juan area is open to conjecture.

\section{MIDDLE TERTIARY DEPOSITS}

\section{AGUADA FORMATION}

According to Zapp and others (1948) the basal middle Tertiary in the San Juan area is the Aguada limestone of early Miocene age. Inasmuch as the formation consists predominantly of noncarbonate rocks in this area (see below), the designation in the San Juan area is hereby changed to Aguada formation to allow for the indicated lithologic variation. The contact of these beds with the older complex rocks has not been seen, but it is undoubtedly marked by an angular unconformity. Several water wells (McGuinness, 1946, wells Gb 17, Gb 22, and others) in the vicinity of Montes de Caneja, which reached the older complex beneath the middle Tertiary, show that the unconformity is an irregular surface here. The possibility exists that these irregularities are due to faulting, but there is no reason to think that a boundary fault separates the older complex and the middle Tertiary deposits in the San Juan area.

The beds assigned to the Aguada formation crop out as soil-covered rounded slopes and tepee-shaped hills east and west of Río Piedras. This topographic form is in contrast with that developed on the overlying dense Aymamón limestone, which generally forms karst hills with steep rocky slopes.

Several excellent exposures of the Aguada formation in the San Juan area-for example, at the base of the Montes de San Patricio (pl. 9B) and in a quarry just west of the Bayamón District Hospital west of the map area-as well as cuttings and samples from many water wells show that in this meridian the formation consists predominantly of marly clay, clay with small lime nodules, silty and sandy clay, sands that in places are highly quartzose, gravel, and some nodular calcareous sandstone. Limestone as such, and particularly dense limestone, occurs only sparsely and generally as thin lenses. The section exposed in the quarry on Highway 2, just west of the mapped area $(183,900 \mathrm{~m}, 62,930 \mathrm{~m})$, is considered typical of the formation in the area. All beds and units vary in thickness in the section that follows:

Section of Aguado formation exposed in quarry west of Bayambn District Hospital $(183,900 \mathrm{~m}, 62,930 \mathrm{~m})$

Unit

Lithologic description

Approximate thick-

1. Silt, light greenish gray, compact, sandy, with brown mottling. Upper part rich in hard white chalky lime nodules. Only lower part exposed in quarry face............

2. Sand, dark brownish gray, slightly cemented; contains rounded pitted masses of fossiliferous red calcareous sandstone up to 5 feet across. Overlying these nodules at one place is a concentration of black sand. The top of this unit is a possible paleosol(?), consisting of 6-8 inches of 'deep \{reddish brown, medium-coarse sand with slight clay binder and with thin clay partings rich in fossil leaves. ..................

3. Sand, brown, silty, fine to coarse; occurring in a lens with angular hard calcareous sandstone nodules, coarse angular gravel, light-green and brown mottled silt....... -

4. Sand and gravel, medium to coarse angular to subangular. Sand consists mostly of quartz, chert, and miscellaneous rock fragments. Gravel up to 4 inches in size. Quartz and chert pebbles common. Some weathered andesite and tuff............ 
Section of Aguado formation exposed in quarry west of Bayamon District Hospital $(189,900 \mathrm{~m}, 62,930 \mathrm{~m})$-Continued Unithologic description
5. Clay, silty, slightly mottled, green, and fine
sandy clayey silt. Clay is plastic and soapy to the touch. Unfossiliferous.....

6. Sand, clayey, light green, with slight cohesion due to a plastic green clay binder. Sand predominantly quartz. Top 16 inches is iron-stained. Unfossiliferous. Variable in

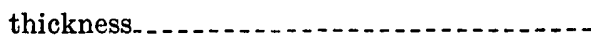

7. Sand, medium-coarse, light brownish-gray, with some lime cementation. A few scattered pebbles up to 2 inches in size.......

8. Clay, sandy, mottled light green and light brown. Sand is mostly angular clear quartz

To1 al Aguado formation exposed.....

Approximate thick.
ness (feet)

6

4

6

$\equiv 4$

62. 5

Exposed about the base of the Montes de San Patricio are the green nodular clays of unit 1 (above), which apparently characterize the upper part of the Aguada formation in this area.

It is estimated that about 325 feet of predominantly clastic sediment make up the Aguada formation in the San Juan area. The 255-foot water well of the Caparra Dairy (McGuinness, 1946, well Gb 38 ) is entirely in this formation.

There is some question whether the formational name Aguada is correctly applied to all of these beds. According to Zapp and others (1948), the Aguada formation possesses the following characteristics: (1) It underlies the dense limestones of the Aymamón formation; (2) it possesses a fauna of Miocene aspect like the overlying Aymamón limestone; and (3) it consists essentially of interbedded pure limestone and softer chalky to marly limestone, although up to 32 feet of basal sand, gravel, and shale occur where the formation rests directly on the Cretaceous rocks.

It is clear that the predominant limestone lithology of the Aguada formation, as described by Zapp and his co-workers does not characterize the section in the San Juan area, where from a lithologic standpoint the beds more nearly resemble the noncarbonate clastic subdivisions of their Río Guatemala group of late Oligocene age, which according to these authors does not occur in the San Juan area. Inasmuch as no paleontologic study was made of the middle Tertiary section of the San Juan area in the preparation of this report, the formational assignment can not be examined in the light of the age criteria. The possibility should be recognized, therefore, that the Rio Guatemala group is represented in part in the
San Juan area, although it is also possible, as indicated by the authors mentioned, that the beds in the San Juan area are simply a thick, noncarbonate, clastic facies of the Aguada formation.

\section{AYMAMÓN LIMESTONE}

Overlying the clastic sediments of the Aguada formation are medium- to thick-bedded, dense, white to pink limestone and minor amounts of marl, sand, and clay that Zapp and others (1948) have termed the Aymamón limestone. This formation is the uppermost unit of the middle Tertiary section of the north-coastal plain as recognized by these authors, and is of early Miocene age.

The contact of the Aymamón limestone with the Aguado formation, where exposed northwest of Suchville and in the sides of the Montes de San Patricio, is sharp and generally conformable, although there is a slight irregularity and angularity of the bedding above and below the contact at the east end of the Montes de San Patricio.

Outcrops of the Aymamón limestone are marked by prominent hills with steep to vertical rocky slopes, a peculiar form well illustrated by the Montes de Caneja. This haystack type of outcrop is in marked contrast to the low rolling slopes of the underlying Aguada formation. The Aymamón limestone is cavernous and scored by deep solution pits. Vegetation is rooted in the soil-filled crevices and pits on otherwise almost soilless slopes.

The Aymamón limestone is prevailingly medium bedded. In natural exposures, however, it appears to be thick bedded to massive, owing to a coating of caliche (secondary $\mathrm{CaCO}_{3}$ ) which tends to seal and obliterate much of the bedding and to mask the thin marly and sandy beds. In addition, caliche commonly cements together loose surface rubble into massive deposits of somewhat iron-stained, honeycombed rock.

The total thickness of the Aymamón limestone is not known, but from the width of its outcrop and by assuming an average north dip of $4^{\circ}$, it is computed that roughly 950 feet of Aymamón limestone underlies the island of San Juan. Yet, geophysical exploration by seismic method at Palo Seco, about 1 mile west of the San Juan area, suggests that close to 3,000 feet of middle Tertiary sedimentary rocks occurs there, indicating that the middle Tertiary section thickens strongly northward (Kaye, 1957). The Aymamón limestone may therefore aggregate a thickness of well over 2,000 feet at the latitude of the coast. 
Age.-The Aguada formation and the Aymamón limestone are both placed in the early Miocene by Zapp and others (1948). As already pointed out, however, there are lithologic grounds for suspecting that part, at least, of the beds mapped as Aguada in this report may rightfully belong to what Zapp and others refer to as the Río Guatemala group. The age of those beds is late Oligocene (employing the twofold subdivision of the Caribbean Oligocene as suggested by Woodring and Thompson, 1949).

\section{LATE TERTIARY(P) AND QUATERNARY DEPOSITS} OLDER ALUUVIUM

Widespread though discontinuous clayey and sandy deposits, whose origin and interrelationship are not,entirely clear and which may include some residual soil, colluvium, and even estuarine sediments as well as alluvium (in the strict sense of the word) are lumped under the term "older alluvium" to differentiate them from the present-day flood plain sediments. The most characteristic features of these deposits are (1) the lack of relationship to present stream alluviation, inasmuch as the deposits occur in either high-stream terraces or on upper slopes and interfluves, and (2) the extensive conversion of nonquartz components to clay. The deposits now consist mostly of red, or mottled red and white, silty clays with variable amounts of quartz sand. In many places the original sand or gravel texture is still apparent to the eye in spite of the advanced state of alteration. Locally, as for example just north of the Penitenciaría, the older alluvium is predominantly thinly stratified clayey quartz sand.

In a few places fresh exposures showed high-angle faults, although surface expression of the faults was absent. In at least one place, however, this faulting might have been caused by collapse of the underlying middle Tertiary limestone, and one hesitates to conclude that any of it has a tectonic origin.

The reticulated mottling commonly found in these red clayey deposits is a striking feature, consisting generally of a somewhat crisscross pattern of veins, an inch or less in width, of white and buff clay. The central part of a typical vein consists of the white (light gray when moist) clay, and the buff clay composes an intermediate zone separating the white clay. from the red. The white clay is more plastic than the red and, according to standard hydrometer tests, contains a greater percentage of material of colloidal dimensions. Both in plasticity and in grain size, the buff clay is intermediate between the red and the white clay. Roberts and others (1942, p.
458) report that the white-vein clay is higher in alumina and lower in iron and silica than the red clay. The white clay seems to be clearly the result of the alteration of the red, in which a leaching of the iron and the peptization of the clay particles, with a possible change in clay mineralogy, has taken place. The buff clay is the intermediate stage in the alteration of red clay to white. The alteration of the original red clay was probably localized along the paths of roots, as the pattern of reticulations not uncommonly suggests, and along shrinkage cracks. Alteration was brought about by percolating water charged with organic acids from the soil zone. This process is called "gleying" by pedologists (Robinson, 1949, p. 191-192).

Some of the best-developed veination seen by the writer was in the bottom of caisson excavations on the south side of San Juan Bay, where older alluvium was exposed at altitude 29 feet below mean sea level, beneath 30 feet of organic bay mud.

The contact between the older alluvium and the underlying bedrock is generally sharp. A thin pavement of pebbles and cobbles, among which fragments of vein quartz are particularly conspicuous, commonly marks the base of the older alluvium. The deposits are very variable in thickness and may exceed 100 feet in places.

The sandy clay of the older alluvium is particularly widespread betwen Trujillo Alto and Guaynabo, where it obscures the bedrock in the uplands, but is generally thin to absent on the valley sides. The full distribution of these deposits has not been shown on the geologic map (pl. 2) because of the difficulty in outlining them. Several areas where their presence is particularly obvious have been indicated, however, although even here the contact has been generalized.

The age of the older alluvium may be early Pleistocene or even late Pliocene. There is no direct evidence for dating the deposits. All that can be said is that considerable topographic and mineralogic decomposition has taken place since their deposition.

\section{PLEISTOCENE LITTORAL DEPOSITS}

Only a brief résumé of these and allied deposits will be given here; they are described in considerable detail in chapter $B$.

The friable, generally somewhat crossbedded sandstone that underlies the higher parts of Isla San Juan and Santurce as well as the offshore islets is mostly eolianite (cemented dune sand). At San Juan, four generations of dune accumulations 
can be recognized, each separated from the other by paleosols (ancient soils). In addition there is reef rock and associated littoral marine sandstone, which seem to provide the foundation for the series of superimposed dunes that were later cemented to eolianite. The best exposures of both eolianite and reef rock are in the cliffs on the north side of Isla San Juan.

Owing to limitations of the map scale, the four eolianites on Isla San Juan are not separated on the geological map. All of them have the same characteristics. They are typically thin-bedded, medium-grained sandstone, very friable where freshly exposed but with appreciable casehardening on longexposed surfaces. They are generally lacking in megafossils. On the higher hills of Santurce, the eolianite is mostly blanketed with a red sandy soil; but it is occasionally exposed in building foundations.

The ages of the several eolianites and the elevated reef rock are discussed in chapter $B$. They are thought to fall entirely within the Quaternary.

SANTURCE SAND

The name Santurce sand is proposed for the widespread deposit of quartz sand (glass sand, see Thorp and Smith, 1933) and interbedded somewhat clayey quartz sand that form the surficial deposit of much of the coastal plain of the Puerto Rican north coast. The color of these deposits is characteristically white, though bright red occurs in places. The deposits are particularly thick under the low-lying areas on the western side of Santurce and are therefore named after this place. The white quartz sands and clayey sands also occur east of San Juan, where, however, they are covered by Recent littoral sands. Deposits of quartz sand occur widely as discontinuous surface deposits for a distance of 50 miles west of San Juan, both on the coastal plain and on the broader bottomlands between the haystack hills of the middle Tertiary limestone.

The outcrop of the Santurce sand is generally a loose, very well sorted, medium-grained sand without apparent stratification, pure white to light gray in color. In places the sand is slightly clayey and as a result has some cohesion. Surficially, this clay may be weathered deep red, thereby imparting a red color to the whole mass. The sand consists of more than 99 percent of angular to subangular clear quartz.

A foundation boring next to the Puerto Rico Water Resources building on Avenida Ponce de Léon, Santurce, $(190,125 \mathrm{~m}, 68,700 \mathrm{~m})$ penetrated 80 feet of quartz sand and slightly clayey quartz sand without reaching the bottom of the deposit. The elevation of the bottom of this boring was at approximately 70 feet below sea level. Borings in the U. S. Naval Reservation penetrated 100 feet of the deposit (Don U. Deere, oral communication). The maximum thickness of the deposit is not known.

Besides its nearly pure quartz composition, the folowing features of the Santurce sand are worthy of note: (1) The great uniformity of sorting of the sand component. All samples of sand studied from seven borings at a large office-building site $(190,125$ $\mathrm{m}, 68,700 \mathrm{~m}$ ) shawed a median grain size of $0.35 \mathrm{~mm}$ and a sorting coefficient ranging from 1.30 to 1.35 . (2) The lack of any carbonate cementing material. (3) The cohesive nature of the clay binder, which generally constitutes less than 15 percent by dry weight of the total sample and yet imparts a great dry strength and gives the sand a somewhat rubbery consistency when moist. (4) The light-gray to white color of the clay component. (5) The erratic variations in the density of the sand with depth. The last factor was revealed by penetration tests in the course of the foundation borings just referred to. By measuring the number of hammer blows required to drive a split sampling spoon a foot under constant conditions, it was shown that the sand varies considerably and erratically in density of packing with depth. (6) The lack of fossils. (7) It widespread distribution on the lowlands of the north coastal area.

The problem of the origin of these sands has been examined by Thorp and Smith (1933). These authors concluded that the sands were derived from the leaching of limestone of middle Tertiary age, with some wind-blown addition from nearby beach sediments. The white color-or absence of iron staining-they attributed to gleying or podzolic leaching, in which the iron of poorly drained soils is leached by water rich in organic acids. If this is true, the Santurce sand represents the end product of the bleaching process that was advanced above as the explanation for the white veinations in the older alluvium. The sand gives some evidence, however, of possessing a depositional history somewhat different from that of the older alluvium; and very likely it is stratigraphically distinct from the older alluvium. The uniformity of grain size and paucity of clay point to a rather special sedimentary environment that in part, at least, is certainly eolian. The deposits may be simply the result of a reworking of the older alluvium, which, it will be recalled, is thor- 
oughly decomposed except for quartz. In essence the process of concentration is the washing and winnowing out of clay. Older alluvium is being actively eroded today, and where slopes are gentle, as in the middle Tertiary belt, the quartzose older alluvium is base-levelled mostly by sheet erosion. This results in the removal of the clay and the formation of a thin lag residue of quartz sand, which in places has been concentrated by wind action into low dunes. Most of the quartz sand used for glass manufacture is dug from these eolian accumulations. In the broad valleys between the haystack hills the eolian deposits are generally thin-10 feet or less. On the lowland of the coastal plain to the north, and particularly in the lagoonal basins in back of the shore, wind deposited accumulations are thicker. Some concentration of quartz sand is of a deltaic nature. Small streams draining the older alluvium tend to deposit the quartz sand on their flood plains or as low alluvial fans on the coastal lowland. It seems very possible, then, that a combination of selective alluvial sorting and wind deposition has built up the 100 and more feet of Santurce sand and clayey sand around the western edge of Santurce. The white color of the clay binder seems most logically accounted for by Thorp and Smith's idea of the podzolic leaching of iron oxide by acidic water, particularly the poorly oxygenated waters of the bay and lagoons.

Because the winnowing out of quartz from the older alluvium is a continuing process, going on even today, the age of the Santurce sand probably includes material ranging in age from Pliocene(?) to Pleistocene, and possibly may include some Recent sand.

\section{RECENT LITTORAL DEPOSITS}

Recent littoral deposits consist of beach sand and deposits derived from beach sand, such as low foredunes, beach ridges and broad flat sand aprons that generally spread behind the beaches proper. Recent littoral sand apparently reaches a thickness of 40 or more feet (as at the site of the new International Adrport, in the northeast quarter of the map area), and represents both normal beach accumulations and wind and storm-wave reworking of beach sands.

The littoral sands are generally medium to coarse; and in the San Juan area they consist of a mixture of mineral grains (predominantly clear quartz), comminuted shell, fragments of calcareous algae, and tests of Foraminifera. Although there is considerable variation in the relative proportion of organic and nonorganic components from place to place, nonorganic (mineral) grains make up the largest part of most samples of sand studied from the San Juan area.

\section{BEACHROCK}

In places along the coast, beach sand is cemented in the intertidal zone into a hard pavement. The cement is generally $\mathrm{CaCO}_{3}$ but in one place in the quadrangle it is iron oxide. This cementation is apparently an active process that is going on in some places at the present time. In the San Juan area the beachrock exposed in the bight east of Punta EI Medio is a particularly fine example of beachrock pavement. An unusual type of beachrock cementation occurs in front of the Medical School in San Juan. Here the cement is a black magnetic iron oxide. Besides the normal sand this rock also contains a large assortment of broken crockery, glass, bricks, wire, and other components of a former rubbish heap.

\section{BAY MUD}

Soft, black, highly organic clay (muck) and lesser amounts of rather clayey peat underlie and rim part of the bay and the several lagoons. These deposits, referred to locally as bay muds, form broad mangrove swamps where they are exposed and unreclaimed. Excavation through the bay mud, by means of caissons at the site of the steam-generating plant on the south shore of the bay, showed that it contained mollusk shells of existing lagoonal species whose original coloration had been destroyed, probably by the strong bleaching action of the hydrogen sulfide generated in these muds. The muds rest on rather compact mottled clays and sandy clays of the older alluvium. The thickness of the bay muds around Bahía de San Juan generally ranges from 25 to 35 feet but one boring on the north side of the bay, at the U.S. Naval Reservation, showed a thickness of 90 feet.

The muds are apparently derived from the fine clay that is carried into the bay by streams, to which has been added a large admixture of bay-derived organic material that is preserved by the reducing environment prevailing in this poorly circulated body of water.

\section{RECENT ALLUVIUM}

Gray to red alluvial clays occur on the broad, poorly drained meadows flanking the bay. The complex history of the alluvial fill in the San Juan area is indicated in a water well at the Rum Pilot Plant, 
less than a mile southwest of Río Piedras. This well penetrated a surface deposit of 18 feet of slightly plastic red silty clay, beneath which was 90 feet of alluvial material, varying in texture from gravel to highly organic clay. How much of the sediment can be referred to the older alluvium and how much to more recent deposition is problematical, although the part occurring below sea level (that is, below a depth of 55 feet) is possibly correlated with Pleistocene lower sea levels and therefore, by definition, would be excluded from the category of Recent alluvium.

\section{Log of water well at the Rum Pilot Plant,} Insular Agricultural Experiment Station.

Approximate altitude of top of hole, 55 feet.

Clay, red, silty 0-18

Silt, yellow; with trace of sand

Clay, plastic, yellow-brown; with trace of sand _.._-25-33

Gravel, clayey; consists mostly of ashy siltstone of the Fajardo formation 33-38

Gravel, well-rounded; consists mostly of rocks characteristic of the Fajardo formation

Clay, sandy, grayish-brown; with some gravel

Sand, silty, micaceous, greenish-gray and reddishconsists of subangular quartz, feldspar, and tuffaceous rock fragments $50-55$

Sand, silty, micaceous, greenish-gray and reddish brown

Clay, organically rich, dark gray and black; includes some sand and fine gravel ___________-_ 80-103

Gravel, medium- to fine-grained; consists of a wide variety of older complex rock types __________103-108

Bedrock, green hornfels (?). Only a few small cuttings were available $108-200$

\section{STRUCTURE}

The rocks of the older complex are greatly deformed; those of the middle Tertiary, much less so; and the younger deposits, not at all or, from a tectonic point of view, negligibly so (Kaye, 1957). More precisely, the older complex is folded and badly broken by faults (fig. 5), whereas the deformation of the middle Tertiary rocks consists of a gentle northerly tilt with superimposed minor undulations and possibly very shallow folds. Faulting of the middle Tertiary in the San Juan area is on a small scale (pl. 9B).

The older complex rocks in the San Juan area are folded into several relatively large, fairly symmetrical flexures (pls. 7B, 8). This, in the writer's experience, is typical of the folding of the older complex throughout the island; tight folds or much overturned folds are rare (Kaye, 1957). Except for the northeast and southwest corners of the island, which are characterized by prevailingly easterly strikes, and in the vicinity of the larger plutons, the general trend of folds throughout most of Puerto Rico is northwest. The San Juan area lies athwart the boundary between the east- and northwest-trending structural belts and contains folds that show the characteristics of both alinements.

The structural picture of the Puerto Rican older complex, in spite of the simplicity of the overall fold pattern, is nowhere easy to decipher. The difficulty in interpreting scattered structural observations is due in part to the wealth of unconformities, facies changes, and the uncertainty of the magnitude and direction of initial dips in these rocks. Perhaps more important than these factors are faults. Almost every sizable exposure of the older complex shows one or more faults (pl. $9 A$ ), and the impression is conveyed that the relatively simple structural fabric of the older complex is almost everywhere shattered to some degree by a dense network of small and large fractures.

The structural picture of the San Juan area is dominated by a large thrust fault (fig. 5) which from its inferred trace seems to vary from low angle (on the west) to high angle (on the east). The fault dips north and its trace crosses the mapped area in a prevailingly easterly direction. A small outlier or klippe of this thrust sheet possibly occurs northeast of El Laberinto, where it seems to be bounded by strongly oblique tear faults. Horizontal displacement along the thrust is estimated to have exceeded 3 miles, the upper plate moving south relative to the lower block. The fault trace is exposed at only a few places, and its position for the most part has been inferred from otherwise irreconcilable discordances in the attitudes of the rocks on both sides of the fault, and from the otherwise unexplainable juxtaposition of different stratigraphic units.

The structure of the overthrust sheet in the San Juan area is a broad, essentially east-west anticline that plunges to the west. The cuesta of the Montes de Hatillo forms the north flank of this fold, and the ridges west of Guaynabo mark the west closure. A fragment of the south flank is preserved in a downfaulted wedge of the thrust sheet, several miles south of Guaynabo. Dips in this fold are as high as $45^{\circ}$ but in general are between $20^{\circ}$ and $30^{\circ}$. Small drag folds and minor undulations are common features in the relatively incompetent ashy siltstones and bedded cherts of the Fajardo formation, which forms part of the overthrust plate.

The rocks beneath the thrust sheet are strongly faulted but preserve the essential features of an 


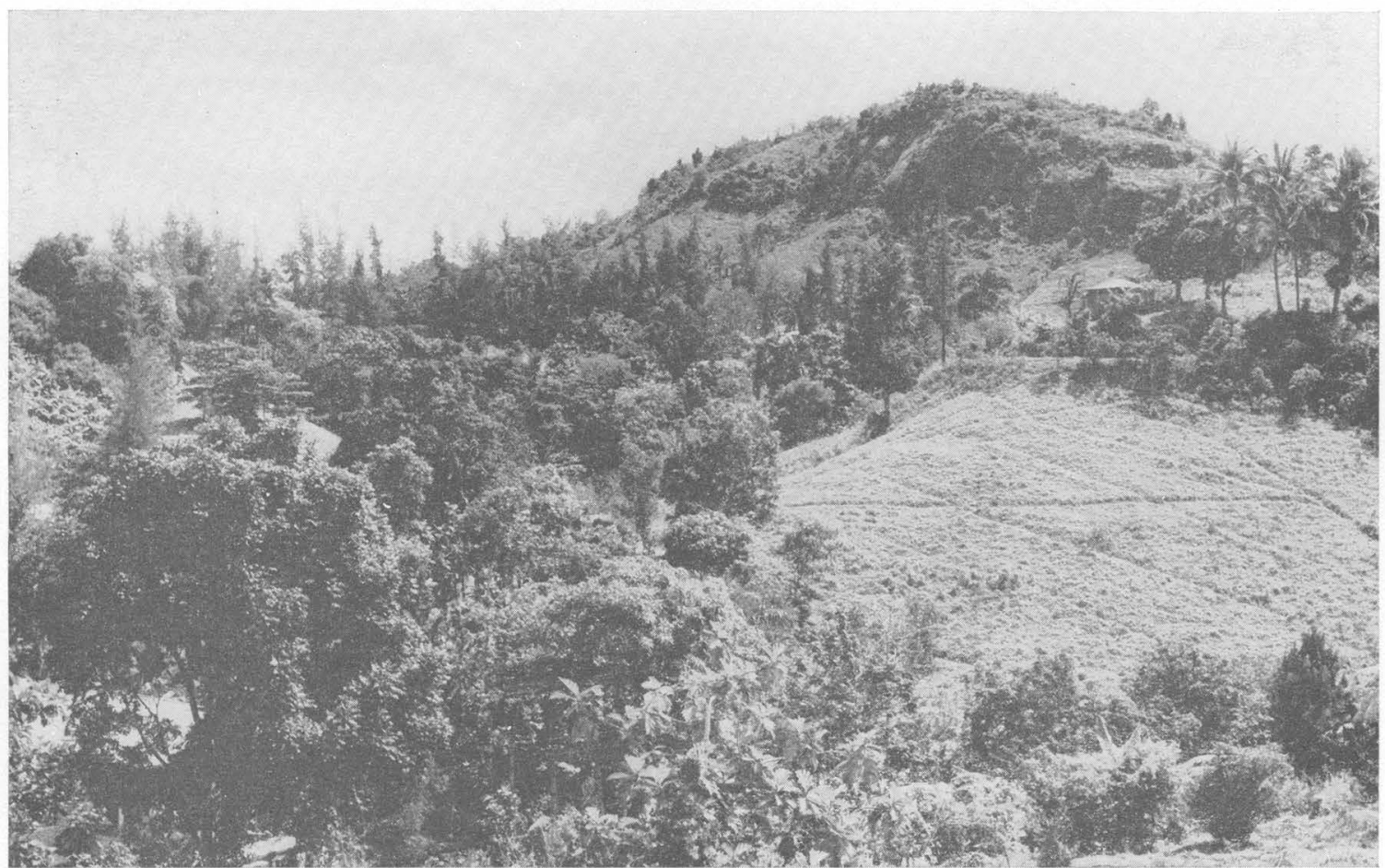

A. GUAYNABO FAULT SCARP; ABOUT TWO MILES SOUTHEAST OF GUAYNABO

ELEVATED BLOCK IS HORNBLENDE ANDESITE BRECCIA OF THE FIGUERA VOLCANICS

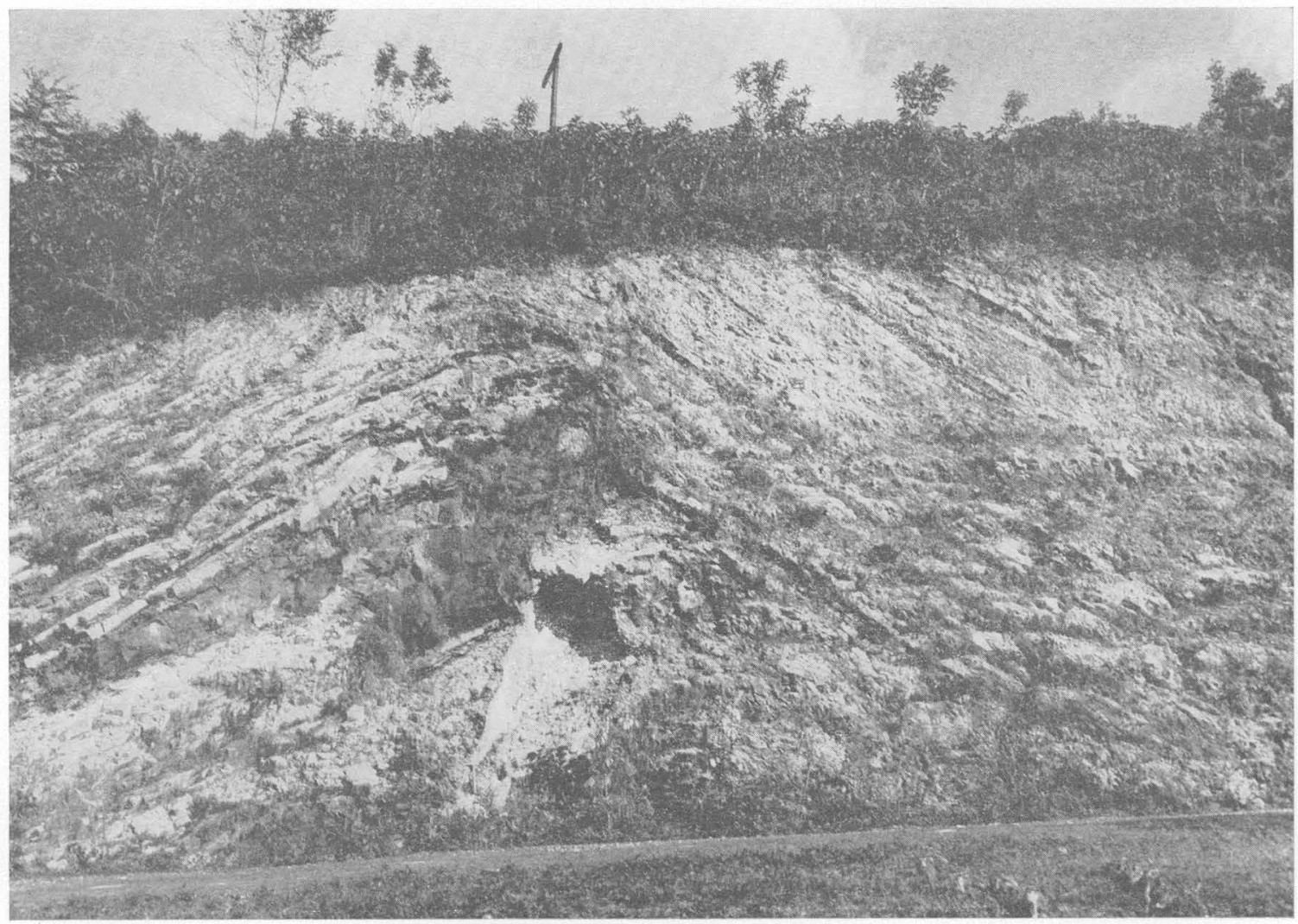

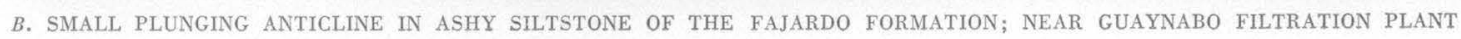




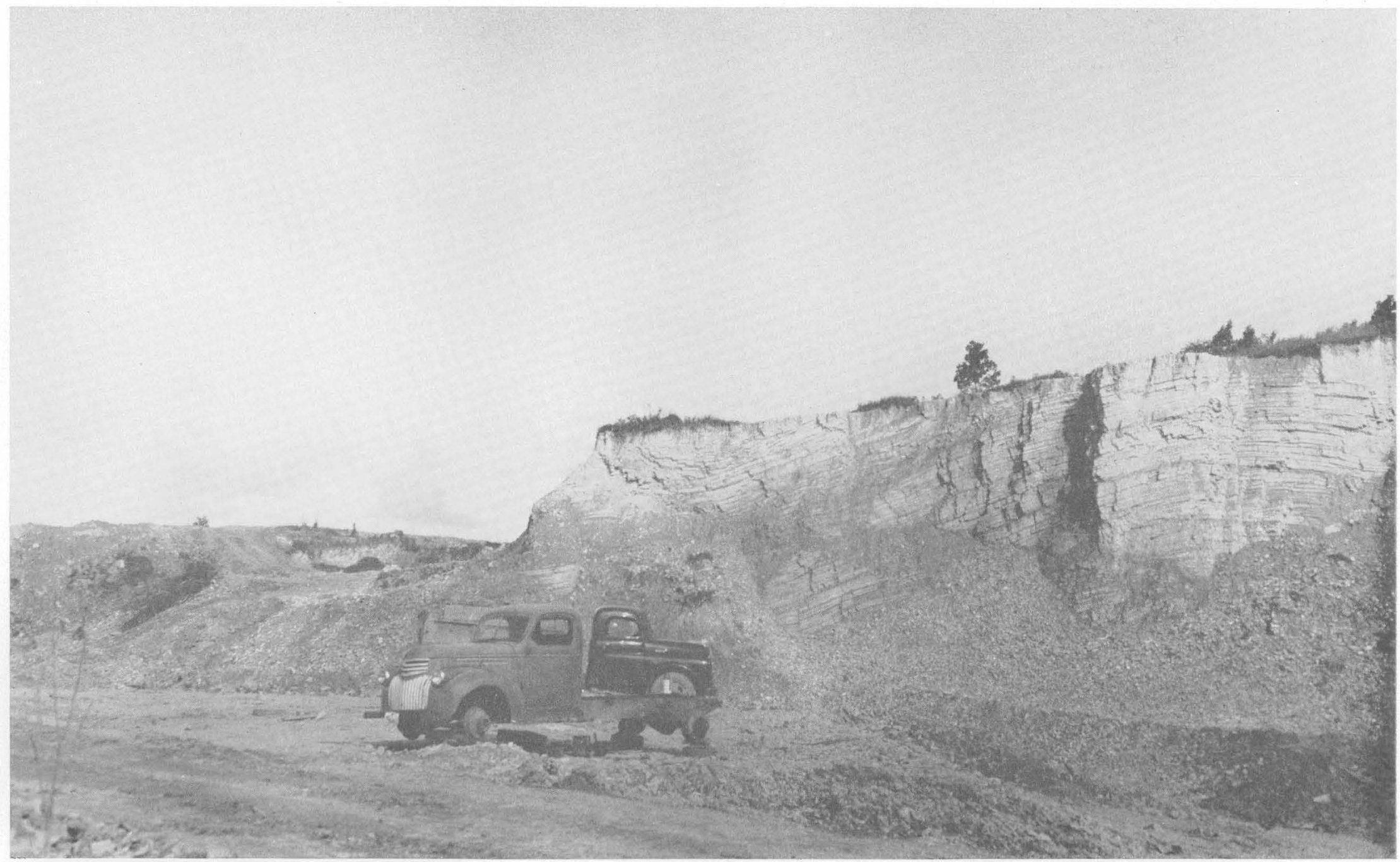

GENTLE FOLDING IN ASHY SILTSTONE OF THE FAJARDO FORMATION. SCARP AT LEFT OF QUARRY FACE WAS FORMED BY A LARGE ROCK SLIDE 


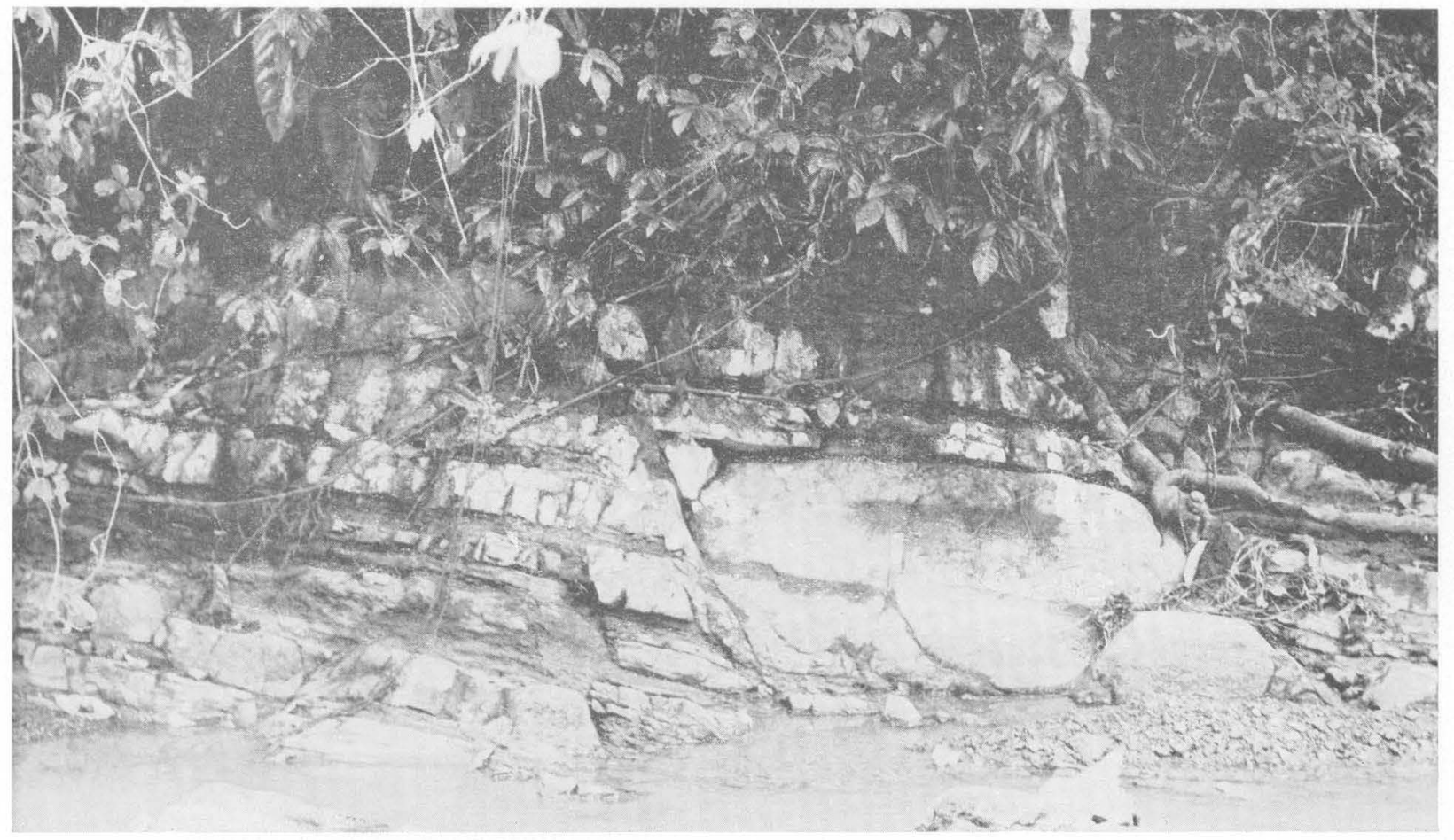

A. SMALL FAULT IN GRAYWACKE AND SHALE OF THE GUAYNABO FORMATION

Photograph also illustrates the occurrence of relatively unweathered rock in the streambeds of the deeper valleys

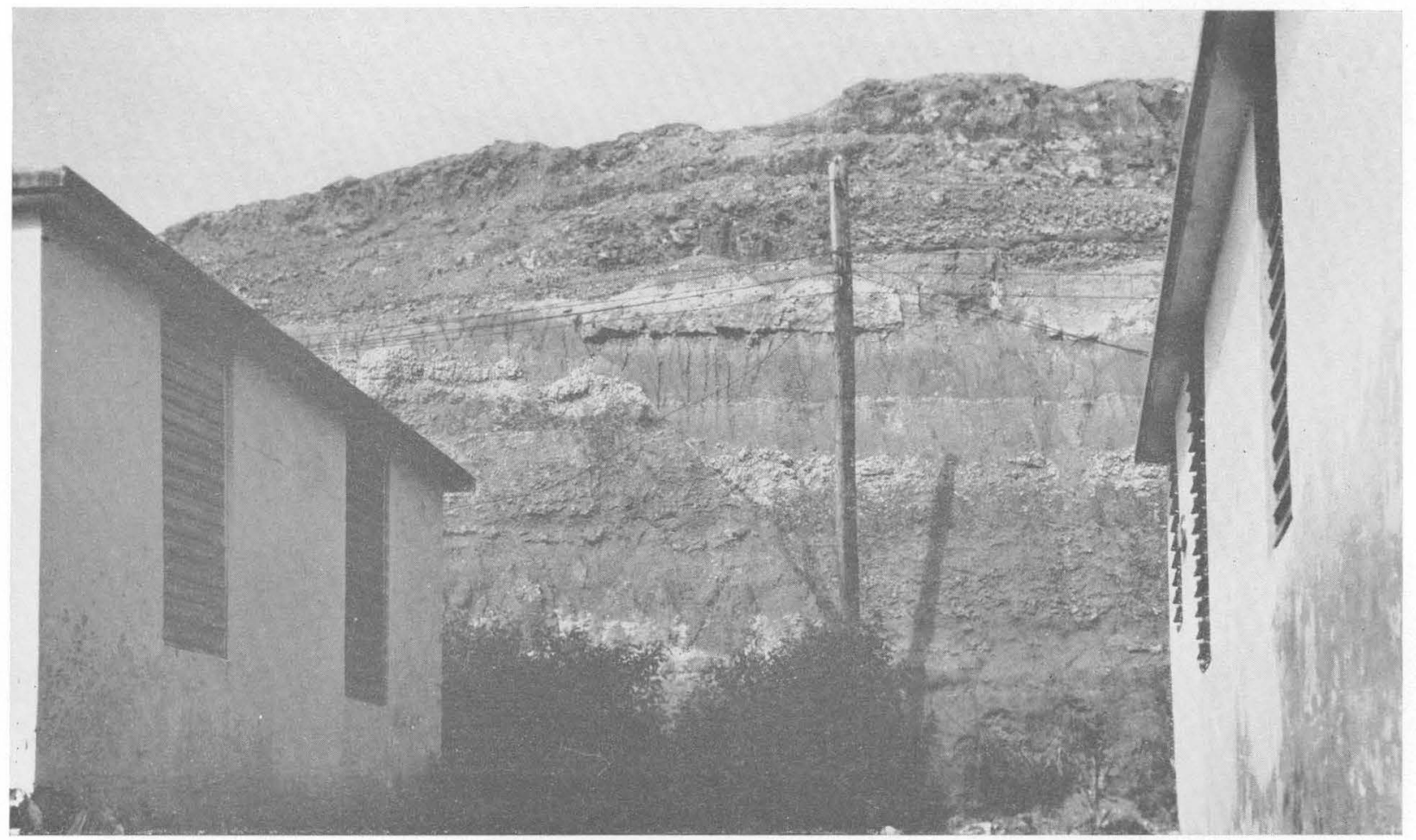

B. SMALl Normal FAULT IN VARIEGATEd SANDS AND MARLS OF THE AGUADA FORMATION; AT THE EAST END OF tHE MONTES DE SAN PATRICIO 


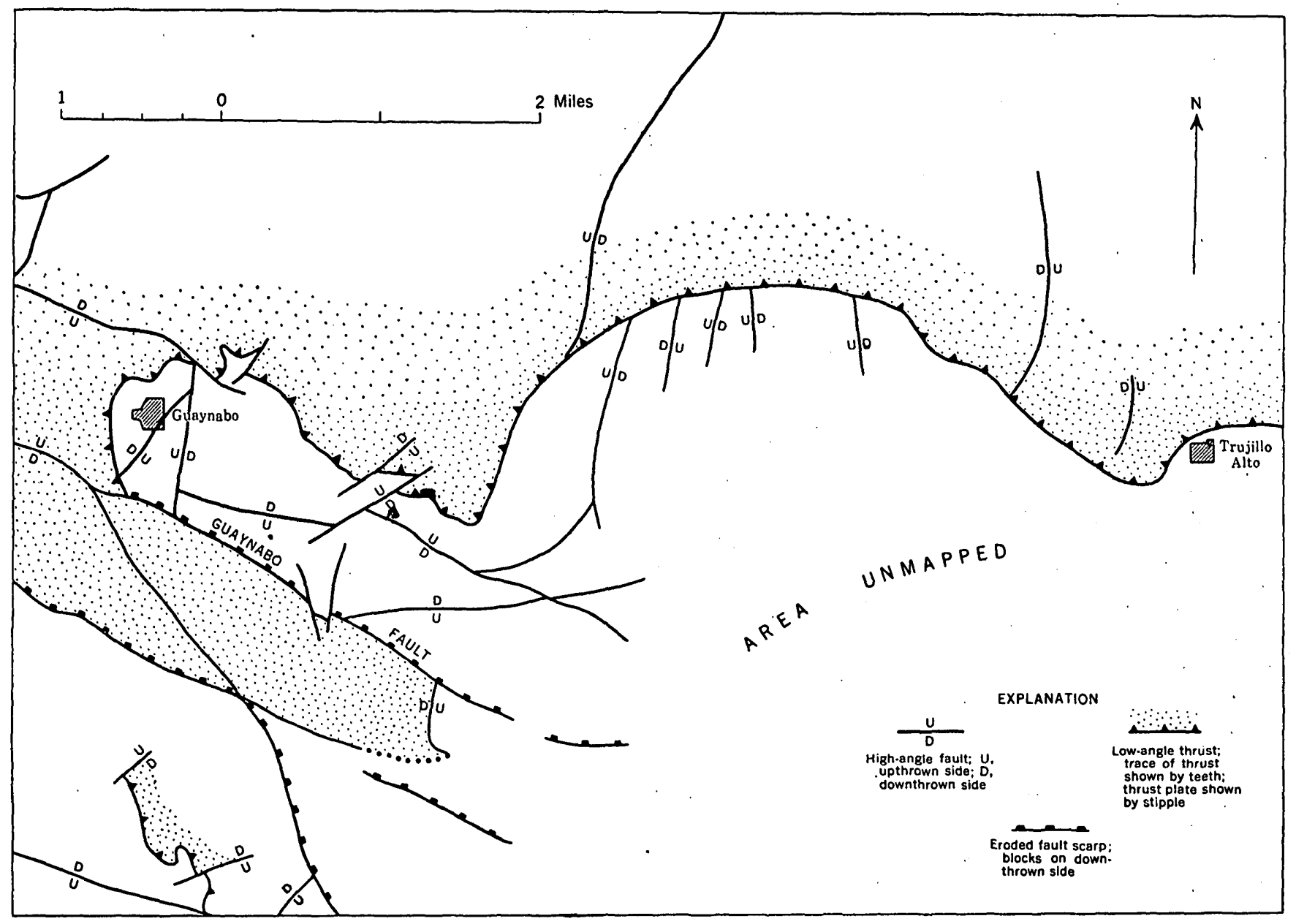

FIaURE 5.-Major known and inferred faults in the older complex in the San Juan area.

anticline whose axis in the southern part of the mapped area inscribes an arc that is concave to the north. This broad structure, which encompasses the entire mapped area south of the overthrust, shows by its flexed axis the influence of both the northwesterly and easterly structural trends already mentioned. The west end of the fold conforms to the northwesterly trend that prevails for many miles to its south and west. The east part of the fold shows evidence of having been dragged around to conform to the prevailingly easterly to slightly northeasterly trend that has been noted by the writer at several localities east of the San Juan area. Minor undulations and ill-defined folds occur on the flanks of this larger structure, like the east-trending chain of small synclinal sags at about the latitude of the village of Guaynabo. The plunging west end of one of these folds is discernible in the first road cuts just south of this village.

High-angle faulting both preceded and followed displacements along the large thrust fault already mentioned. As a result, some of these faults are mappable only to the trace of the overthrust, whereas others displace the trace of this major feature. Moreover, several of the faults in the La Muda area show a complex history, in which the earliest movement preceded the intrusion of the granodiorite porphyry, but with postintrusion movement along at least sections of these faults. In addition, reversal in the relative direction of fault movement is indicated in at least two large faults.

The strikes of the major high-angle faults form a conjugate pattern of two dominant trends, westnorthwesterly and east-northeasterly (fig. 5). The west-northwesterly set is more strongly developed and probably has been active over a longer period of time.

Most of the northwest-trending faults are downthrown toward the north. An exception to this is the fault which bounds the Figuera andesite block on the north side, crossing the Guaynabo road about half a mile south of that village, and which is here called 
the Guaynabo fault. Stratigraphic evidence shows that the upthrown side of this fault is the north side, although today its prominent north-facing scarp (pl. $7 A$ ) probably records a relatively recent (late Tertiary? or Quaternary) reversal of movement. The Guaynabo fault and a small cross fault that slightly offsets the Guaynabo fault are both well exposed in the sides of the new highway north of La Muda. At this place the fault is vertical and is marked by a breccia zone only 2 feet wide. The thin cataclastic zone of this fault is typical of most faults seen in the San Juan area. An exception to this is a gouge zone, over 150 feet wide, of slickensided dark reddishpurple clay containing rolled and rounded breccia fragments of porphyritic andesite that is well exposed in the trail about half a mile east of the Escuela Segunda Unidad de Caimito.

A long, somewhat discontinuous fault, or fault zone, which also trends west-northwest, passes through La Muda. The south side of the fault in the western part of the mapped area is marked by a prominent though much-eroded scarp. Farther east the fault either fades out or is obscured. This fault gives evidence of a long and complex history. Its earliest movement may have been a scissors with a fulcrum close to La Muda. Renewed movement after the intrusion of the granodiorite porphyry seems to have elevated the block bounded by this fault and another steeply dipping fault that crosses it at La Muda. The picture conveyed by these faults and similar cross faults in the area is a plexus of fractures kept active over a long period of time, with changes in the directions of displacement.

Eroded fault scarps, similar to the two just described, occur at many places in Puerto Rico on the north side of the island divide (Kaye, 1957). Generally, though not invariably, they face north and tend to raise the general topographic level of the upland in successive steps. These escarpments are considered to be true fault scarps rather than fault-line scarps and are thought to be the result of extensive block faulting in the Pliocene and possibly Pleistocene. At least two faults in the San Juan area are therefore inferred to have been active in the late Tertiary. Most of the others have probably been inactive since the early Tertiary.

The middle Tertiary beds dip north at angles up to $6^{\circ}$. Undulations in the dip are not apparent to the eye in any one exposure but are detectable from surface study and from geophysical data. A seismic profile made at Palo Seco, on the west side of Bahía de San Juan and just west of the mapped area; indicates that steplike undulations and even very shallow folds developed in what are presumably the middle Tertiary rocks (Kaye, 1957). High-angle normal faults are not uncommon in the middle Tertiary strata, though those exposed in the San Juan area have small displacements (pl. 9B).

\section{SUMMARY OF MAIN GEOLOGIC EVENTS}

The geologic history of the San Juan area can be reconstructed, although with considerable uncertainty; as far back as the origin of the oldest rocks present, the Hato Puerco tuff. Much of this formation was probably deposited subaerially, as an insular cone that is comparable, we might suppose, to one of the volcanic islands of the present Lesser Antilles. The probable center of the cone was south and perhaps east of the area under study. Moreover, the depositional environment of the entire older complex section in the San Juan area appears to have been circuminsular, such that subaerial and submarine deposition took place around one or more volcanic vents in an area of great crustal instability. The settling of the volcanic pile and its sedimentary debris-a settling that probably was erratic in nature-permitted the extensive overlap of thick accumulations of marine sediments onto deposits of subaerial origin; it is possible that the rate of subsidence exceeded the rate of volcanic accretion, so that at times the island may well have foundered completely beneath the level of the sea. The overlap of subaerial deposits onto marine deposits also probably took place with the building out of the cone by fresh ejecta or by the growth of alluvial fans and the deltaic progradation of the shoreline.

A foredeep origin has been hypothesized by Ewing and Worzel (1954) for at least the oldest Antillean deposits. The evidence, however, for marine deposition of the older complex of the San Juan area in moderate to shallow depths includes (1) the shallowwater faunas of the Trujillo Alto limestone, (2) the prevailingly coarse texture of much of the sedimentary rock, and (3) the absence of red shale derived from abyssal red clays and other types of deep-sea oozes. A subaerial depositional environment for some of the flow rocks and sediments is suggested by the absence of pillow structure and the presence of thick sections of tuffaceous sandstone and gravel devoid of marine fossils but containing abundant plant fragments (for example, the Guaynabo formation). Admittedly, the evidence for nonmarine deposition is not conclusive, and the writer's general impression that several formational units of the older com- 
plex are probably nonmarine is certainly open to further study. The nonmarine depositional environment proposed herein is therefore a "best estimate"- one that most rationally accounts for the field facts as they concern the Hato Puerco tuff.

In reconstructing the deposition of the Hato Puerco tuff, we can imagine a composite volcanic island, roughly comparable to the island of Guadaloupe, which was centered somewhat to the south and east of the San Juan area. This geographical position is only relative, for evidence is lacking as to the amount of lateral movement there has been since Late(?) Cretaceous time. The geographic coordinates of the cone of origin were therefore not necessarily those of eastern Puerto Rico today.

The volcanic centers of the ancestral Hato Puerco island might have been dormant or extinct for a considerable time prior to the deposition of the younger deposits. This may have been initiated by a renewal of volcanic activity and the onset of tectonic movement. The sequence of deposition, both volcanic and sedimentary, was very probably broken at any one point by periods of little deposition and considerable erosion, though there are scant data positively reflecting this.

The Tertiary was possibly ushered in by marine inundation, when limestone was deposited and a new cycle of volcanic eruption commenced. In places the volcanism tore up pieces of limestone from the ocean floor and incorporated them with volcanic ejecta. In the San Juan area 3,000 feet or more of hornblende andesite ejecta (Figuera volcanics) piled up a large cinder cone, the top of which may have emerged above sea level. The pattern of volcanic activity then changed, for in the San Juan area 3,000 or more feet of fine ash (the Fajardo formation) accumulated on the ocean floor. This ash, possibly ejected from centers somewhat removed from the San Juan area, was probably largely airborne, raining into the sea directly from the atmosphere and coming to rest on a steadily subsiding ocean bottom. The interfingering of this marine-deposited fine ash with coarser sediments (such as those cropping out a mile and a half west of Guaynabo) point to a source of land-derived sediments probably lying to the south or southwest. We can imagine, then, that in early Tertiary time islands continued to dot the line of the island arc, just as they did in Late Cretaceous time and just as they do in the Lesser Antilles today.

The Fajardo formation is the youngest stratigraphic unit of the older complex in the San Juan area. Between the time it was deposited, probably in the Paleocene or Eocene, and the onset of the deposition of the next youngest rocks in the early Miocene, a profound crustal revolution took place during which occurred most of the folding, faulting, and intrusion of igneous material that characterizes the older complex. This Antillean revolution probably dates from the Eocene, or even possibly the late Paleocene. The older complex was deformed by the orogeny into long, open folds that in most of Puerto Rico were alined northwest-southeast (Kaye, 1957). Strong overturning of folds, or directionally consistent overturning, has not been recognized by the writer in Puerto Rico. A direction of dominant compressive stresses is therefore not evident, and the general picture that is conveyed is one in which faulting has been more important than folding in producing the complex deformation of the structural fabric of the island.

There has been no attempt here to speculate on the forces and the mechanics responsible for the Antillean geosyncline and the incipient island arc just alluded to, so only a few general remarks will be devoted to the mechanics of the Antillean revolution as it applied to Puerto Rico (for recent speculation on the tectonics of island arcs see Ewing and Worzel, 1954; Griggs, 1939; Hess, 1938; Vening Meinesz, 1954). It seems to the writer that the most plausible orogenic mechanism is the deep foundering of a long, narrow northwest-oriented crustal zone that probably coincided with the geosyncline. (An analogous structural trough today may be the Puerto Rican deep.) Into this narrow crustal downwarp, the older complex rocks of the surrounding sills moved by sliding. Descent into the restricted, narrow zone of the downwarp was accompanied by a certain amount of plastic deformation. Such deformation would be marked by the absence of a consistent direction of overturning to the folds and by an increase in intensity of folding with depth within the downwarp. The older complex in Puerto Rico, by its moderate folding, may therefore represent only the upper part of such a downwarped geosynclinal wedge, and with depth the Puerto Rican rocks may be intensely folded and very much metamorphosed, like many of the rocks that crop out in the nearby Dominican Republic and Cuba. Deformation in the uppermost part of such a downwarp, and particularly along the outer margins, would probably be characterized by large-scale thrust faulting (Griggs, 1939; Vening Meinesz, 1954). A possible example of this is the thrust fault in the San Juan area. 
Batholithic intrusion may have occurred as the base of the sinking wedge fused and was converted to magma. Part of the energy for this fusion may have been the high frictional temperatures that were generated in the downwarp. Further sinking of the trough possibly resulted in the squeezing of the magma upwards into the overlying solid part of the sinking wedge. The high hydraulic pressures developed by this mechanism might account for the essentially concordant nature of the small batholiths located in southeastern and central Puerto Rico (Kaye, 1957). In the San Juan area the granodiorite porphyry is possibly an apophysis of this batholith.

Following the downwarp that marked the culmination of the early Tertiary orogeny, the deeply infolded older complex rocks were then uplifted. This was possibly an isostatic adjustment to the wedge of relatively light crustal material that had been dragged deep into the dense subcrust by the downwarp. By a relaxation of the stresses that may have been responsible for the downwarp, the structural trough rebounded and the disturbed belt arched up isostatically.

From the Eocene to early Oligocene Puerto Rico probably underwent some positive crustal movements, which may have been progressive or interrupted and which may even have included intervals of subsidence. Any sedimentary deposits formed at that time have since been removed by erosion or else are overlapped by the more recent middle Tertiary rocks. By the beginning of late Oligocene time Puerto Rico still presented a rugged aspect. The upper Oligocene coarse basal conglomerates that occur on the north and south flanks of Puerto Rico and the uneven surface of the unconformity that separates the older complex from the middle Tertiary in the western part of the island are evidences of the ruggedness of the terrain.

In late Oligocene time a new structural alinement-destined to characterize all the island's later tectonic vicissitudes-was impressed on Puerto Rico. This was an east-west axis, which marks the shape of the island as well as all of its post-middle Oligocene deformations. The cause of this change from a northwest structural alinement in early Tertiary time to an east-west geanticlinal structure in the middle Tertiary is also speculative. It may somehow be genetically connected with the onset of the sinking of the Puerto Rican trough, an east-west oceanic foredeep lying some 70 miles to the north of the island, although such an interrelationship has yet to be established. One such interrelating mechanism could be the formation of a thermal convection cell in the earth's mantle--different from any that may have contributed to the early Tertiary downwarpthat had a negative side under the foredeep and a positive side under the Puerto Rican axis. But such a facile explanation-assuming that this mechanism were physically possible (see Scheidegger, 1953, for a compelling objection to the convection-current hypothesis)-leaves many questions unanswered.

In any event, by late Oligocene time the north and south flanks of the newly constructed Puerto Rican geanticline were overlapped by marine sediments. Very probably, however, a narrow strip of the axis of the geanticline remained emergent even during maximum flooding in the early Miocene. This deposition continued at least into the late part of early Miocene, and possibly even later. Deposition was terminated with the uplift of the island's axis.

In the San Juan area the first middle Tertiary flooding presumably came not in the late Oligocene but rather in the early Miocene with the deposition of the Aguada sands, silts, and marls. The overlying Aymamón limestone indicates a change to clearer waters or else a growing remoteness of the shore or a diminution of sediment being carried to the ocean by the rivers.

The island that emerged in the middle Miocene seems to have been eroded to an old-age surface by late Miocene or early Pliocene time. This peneplaned surface was then re-arched, but this time mostly by the differential elevation of discrete blocks separated from each other by essentially easterly faults. These fault blocks were mostly confined to the central part of the island. The steplike arrangement that was thereby given to the topography of the island's interior is still crudely preserved. As already mentioned, two such scarps occur in the San Juan area-namely, that which is formed by the Guaynabo fault and that which rises less than a mile to the south (pl. $3 A, 7 A$ ). Some rejuvenation of these scarps by renewal of fault movement throughout Pliocene and early Quaternary time seems likely.

The depositional history of the north coastal area in late Cenozoic time was complex. It is discussed in some detail in Chapter B of this study. In response to alternate rising and falling of sea level during the Pleistocene, a chain of barrier reefs and dunes formed approximately along the present shoreline and are still preserved as low ridges. In many places, such as in the San Juan area, bays and sounds behind these ridges remained; but in others 
the lagoons have filled with organic muds and alluvium, forming broad swanmps or low-lying coastal plains.

\section{ENGINEERING GEOLOGY}

In an urban area like San Juan, the engineering properties of earth materials are of great economic importance. The choice of a construction site, however, is generally controlled by economic rather than purely engineering factors. Grade design and geography idetermine road alinements. Factories are built where they can operate economically and where land at the right price is available, rather than where the foundation problem would be at a minimum. The geologist, who can be of great service in providing the proper kind of guidance and advice during the design and construction phase, finds that for purposes of engineering planning his geologic map becomes relatively unimportant because of the massive economic considerations involved and the technical competence of modern engineering to cope with the most difficult of earth problems-that is, providing the engineer is forewarned by the geologist.

From the standpoint of engineering geology, the older complex cannot be discussed formation by formation. All mapping units (with the exception of the La Muda limestone member of the Frailes formation and the Trujillo Alto limestone) are characterized by rock that is hard, tough, dense, and durable where fresh. Fresh rock, however, generally does not occur at the surface; and unless cuts are deep, surface excavation will involve decomposed rock and silty clay regolith, whose physical properties do not materially differ from one formation to another. Exceptions to this statement are: (1) the clays that occur on the several pure limestones (the La Muda limestone member and Trujillo Alto limestone), which tend to have a higher plasticity than the leaner and more silty clays found on the other rocks; (2) the graywacke of the Guaynabo formation, which tends to yield a somewhat more sandy regolith. Hydrologic factors such as seepage, always an important element in the behavior of earth materials, also do not lend themselves to generalization on a formational basis. The presence or absence of such features as faults, shear zones, or densely jointed zones are important elements here, and these, of course, can be appraised only after site examination. In lieu, therefore, of an attempt to synthesize the engineering properties of the various mapping units, a small sample of geologic questions and their impact on engineering structure in the area will be discussed. Actually there are as many. problems of an engineering geologic nature as there are engineering structures, and the numerical data given below are not meant to be generalized for entire geological formations but should be interpreted simply as samples of what has been found in specific site explorations.

\section{FOUNDATION}

Most modern heavy structures in the San Juan area are built on the Santurce sand, the bay mud, or the older alluvium. The Santurce sand, having a varied density, has therefore a varied strength as foundation for heavy structures. On the basis of empirical formulae (Terzaghi and Peck, $1948 \mathrm{p}$. 423-424), standard penetration tests (Terzaghi and Peck, 1948, p. 265) in the quartz sand at a site in Santurce indicated bearing values for spread footings ranging from 1 to 3 tons per square foot. It was quite clear from this study that the erratic densities of the sand required individual design for each footing or, what is probably the preferred engineering practice, design of all footings on the basis of the lowest bearing value. This situation probably can be anticipated elswhere in the quartz sands.

The bay muds, which form an extensive fringe around San Juan Bay, are the weakest foundation soils in the area. The highly organic clay (mud or muck) is extremely compressible and has a very low strength. Most structures are built on endbearing piles that penetrate the mud and rest on the underlying compact clays. Roads built on the mud settle badly unless the mud has been artificially compressed (consolidated, in the soil mechanics sense of the word). This has been done in the construction of Highway 2 by the use of sand piles (Carpenter, 1948), which are simply vertical holes of large diameter that are backfilled with highly permeable coarse sand. These serve as vertical drains for the pore water in the surrounding mud. As the pore water drains into the sand under the weight of the enbankment fill, the mud compacts. The pavement is laid only after most of the settlement has taken place.

Very compact red clays and sandy clays underlie the bay mud at depths ranging from 25 to 35 feet. These clays are probably the equivalent of the older alluvium. Extensive tests of the clays were made in foundation studies for the steam generating plant of the Puerto Rico Water Resources Authority on the south side of the Bahía de Puerto Nuevo. The 
clay was exposed in caissons, where it was seen to be mottled and veined with white and ochre-colored clay that is characteristic of the older alluvium on the surface. The spread footings for the generating plant rest on the surface of the clay beneath about 30 feet of mud and are designed to carry 3 tons per square foot.

\section{BORROW AND QUARRYING}

The need for fill in the San Juan area is tremendous, and the reclamation of the extensive marshes requires a cheap source of strong run-of-bank material. Several formational units are currently providing the bulk of this. In addition, the universal use of reinforced-concrete construction, coupled with an expanded program of highway construction, demands a cheap and abundant supply of strong rock aggregate and road metal. This too is provided locally. Moreover, portland cement for the concrete is made from locally derived limestone and clay; and clay for constructional tile and brick is quarried and dug within the area.

Economically, the ashy siltstone of the Fajardo formation is one of the most important rock units in the area. Because it is easily excavated and breaks up readily into manageable slabs and blocks along joints and bedding planes, it is widely used for general-purpose fill. A large quarry on the Trujillo Alto road (pl. 8) provides much of this material for the San Juan area. The clayey overburden and the clay intercalations between beds are generally mixed with the rock slabs and provide a certain amount of binder.

Thin flagstone of the less weathered and somewhat siliceous ashy siltstone of the Fajardo formation is very fashionable in ashlar masonry for decorative building facades; it has been used in many buildings erected since 1950 .

The ashy siltstone and intercalated thin white kaolinitic clay is quarried at Saint Just (Highway 848 , just east of the mapped area) for use in the manufacture of brick and constructional tile. The rock is crushed in a pug mill and mixed with a certain amount of alluvial clay that is dug adjacent to the plant (located several miles north of the quarry).

Aymamon limestone is quarried at the west end of the Montes de Caneja for the nearby cement mill. In addition, rubble from this formation is a source of common fill. A certain amount of residual clay generally adheres to the rock and acts as a slight binder.
Rock for crushing, which is used mostly as road metal, is quarried chiefly in the vicinity of Trujillo Alto road (pl. 8) provides much of this material Trujillo Alto vicinity the rocks quarried are: massive amphibolitic tuff (or flows?) of the Hato Puerco tuff; the gray tuffaceous limestone of the Leprocomio member of the Frailes formation; the Trujillo Alto limestone; and, at the east edge of the town of Trujillo Alto itself, augite andesite porphyry. East of La Muda several quarries exploit the Tortugas andesite, and one, the La Muda limestone member of the Frailes formation.

Gravel is dug from the bed of the Río Grande de Loíza, both upstream and downstream from Trujillo Alto. This is the principal source of natural gravel in the San Juan area.

Beach sand was formerly dug from beaches in the San Juan area for concrete aggregate. Fear of inducing accelerated beach erosion, however, led to discontinuance of the practice in the San Juan area, and beach-sand digging is limited to selected stretches of the coast both east and west of the mapped area.

\section{DAMSITE}

The concrete gravity dam across the Río Grande de Loíza, 2 miles south of Trujillo Alto, built by the Puerto Rico Sewer and Aqueduct Authority as a water-supply project for the San Juan metropolitan area, was completed in 1952. The dam is 50 feet high, 700 feet long, and has eight 30 - by 39 -foot tainter gates. Clearing for the abutments and foundation of this dam exposed a particularly good picture of the local geology. The foundation rock is a dense massive andesite or tuff that is altered to a fine-grained amphibolite and probably belongs to the Hato Puerco tuff. It is intruded by a light-colored hornblende diorite and aplite (pl. $5 \mathrm{~B}$ ). Several tightly sealed small shear zones were noted in the foundation but otherwise no faults were observed. The rock exposed in both river bed and abutment excavations was remarkably fresh and required a minimum of stripping, grouting, or other foundation treatment. A thin deposit of sand and gravel in the river bed rarely exceeded 5 feet in thickness. The geologic generalization that can probably be drawn from this is that river downcutting has exceeded the weathering rate of the rocks. In consequence, in the uplands relatively unaltered and fresh rock may be rather common beneath the alluvial beds of major streams, particularly where the valleys are narrow and steep sided. 


\section{ROCK SLIDES}

An interesting rock slide occurred in a large quarry on the Trujillo Alto road (pl. 8), which demonstrated the potential instability of steep excavated slopes in the well-jointed ashy siltstone of the Fajardo formation, particularly if subject to jarring or to strong vibrations.

At the site of the slide the ashy siltstone strata were separated from one another by thin layers of white plastic clay, and the entire section was broken by two sets of joints at approximately right angles. The siltstone, which was exposed in a nearly vertical quarry face approximately 35 feet high, dipped at about 15 degrees toward the quarry floor. It is the writer's opinion that the jarring of the small explosions in the quarry was sufficient to destroy the tenuous cohesion of the siltstone slabs and to set the myriad of newly isolated flags slowly shifting and slipping down along the intervening clay intercalations. The initial state was not unlike that of an unstable pile of greasy dinner plates reposing on a tilted drainboard. In six months much of the hillside behind what had been the quarry face had slowly moved a distance of about 200 feet out into the quarry and the surrounding fields.

\section{REFERENCES CITED}

Berkey, C. P., 1915, Geological reconnoissance of Porto Rico: New York Acad. Sci. Annals, v. 26, p. 1-70.

1919, Introduction to the geology of Porto Rico: New York Acad. Sci., Scientific Survey of Porto Rico and the Virgin Islands, v. 1, pt. 1, p. 11-29.

Carpenter, J. C., 1948, Stabilize muck in Puerto Rico: Eng. News-Rec., v. 141, no. 4, July 22, 1948, p. 52-54.

Daly, R. A., 1933, Igneous rocks and the depths of the earth: New York, McGraw-Hill Book Co., 598 p.

Eskola, Pentii, 1939 Die Entstehung der Gesteine: Berlin, Springer.

Ewing, Maurice, and Worzel, J. L., 1954, Gravity anomalies and structure of the West Indies: Geol. Soc. America Bull., v. 65 , p. $165-174$.

Fenner, C. N., 1950, The chemical kinetics of the Katmai eruption, parts 1 and 2: Am. Jour. Sci., v. 248, p. 593627, 697-725.

Fettke, C. R., 1924, Geology of the Humacao district, Porto Rico: New York Acad. Sci., Scientific Survey of Porto Rico and the Virgin Islands, v. 2, pt. 2, p. 117-197.

Fox, A. J., Jr., 1951, Building water works in Puerto Rico: Eng. News-Rec., v. 146, no. 17, April, 26, 1951, p. 32-35.

George, W. O., 1924, The relation of the physical properties of natural glasses to their chemical composition: Jour. Geology, v. 32, p. 353-372.

Gilbert, C. M., 1938, Welded tuff in eastern California: Geol. Soc. America Bull., v. 49, p. 1829-1862.

Griggs, David, 1939, A theory of mountain building: Am. Jour. Sci., v. 237, p. 611-650.
Hess, H. H., 1938, Gravity anomalies and island arc structure with particular reference to the West Indies: Am. Philos. Soc. Proc., v. 79, p. 71-96.

Hodge, E. T., 1920, Geology of the Coamo-Guayama district, Porto Rico: New York Acad. Sci., Scientific Survey of Porto Rico and the Virgin Islands, v. 1, pt. 2, p. 111-228. Hubbard, Bela, 1923, The geology of the Lares district, Porto Rico: New York Acad. Sci., Scientific Survey of Porto Rico and the Virgin Islands, v. 2, pt. 1, p. 1-115.

Johannsen, Albert, 1932, A descriptive petrography of the igneous rocks, v. 2: Chicago, Ill., Univ. Chicago Press, $421 \mathrm{p}$.

1939, A descriptive petrography of the igneous rocks, v. 1: 2d ed., Chicago, Ill., Univ. Chicago Press, 318 p.

Kaye, C. A., 1956, The lower Tertiary of Puerto Rico: Am. Assoc. Petroleum Geologists Bull., v. 40, p. 108-121.

1957, Notes on the structural geology of Puerto Rico: Geol. Soc. America Bull., v. 68, no. 1, p. 103-117.

Koschmann, A. H., and Gordon, Mackenzie, Jr., 1950, Geology and mineral resources of the Maimón-Hatillo district, Dominican Republic: U. S. Geol. Survey Bull., 964-D, p. 307-359.

Lobeck, A. K., 1922, The physiography of Porto Rico: New York Acad. Sci., Scientific Survey of Porto Rico and the Virgin Islands, v. 1, pt. 4, p. 301-379.

McGuinness, C. L., 1946, Records of wells in Puerto Rico: San Juan, Puerto Rico Aqueduct and Sewer Service, $267 \mathrm{p}$.

Meyerhoff, H. A., 1933, Geology of Puerto Rico: Puerto Rico Univ. Mon. ser. B., no. 1, 306 p.

Meyerhoff, H. A., and Smith, I. F., 1931, The geology of the Fajardo district, Porto Rico: New York Acad. Sci., Scientific Survey of Porto Rico and the Virgin Islands, v. 2, pt. 3, p. 201-360.

Mitchell, G. J., 1922, Geology of the Ponce district, Porto Rico: New York Acad. Sci., Scientific Survey of Porto Rico and the Virgin Islands, v. 1, pt. 3, p. 229-300.

Noble, J. A., 1952, Evaluation of criteria for the forcible intrusion of magma: Jour. Geology, v. 60, p. 34-59.

Nockolds, S. R., 1954, Average chemical composition of some igneous rocks: Geol. Soc. America Bull., v. 65, p. 1007-1032.

Park, C. F., Jr., 1946, The spilite and manganese problems of the Olympic Peninsula, Washington: Am. Jour. Sci., v. 244 , no. 5 , p. $305-323$.

Pico, Rafael, 1950, The geographic regions in Puerto Rico: Río Piedras, Univ. Puerto Rico Press, 256 p.

Roberts, R. C., and others, 1942, Soil survey of Puerto Rico: U. S. Bureau Plant Industry, ser. 1936, no. 8, 503 p., maps.

Robinson, G. W., 1949, Soils, their origin, constitution and classification: 3d ed., London, Thomas Murby \& Co., $573 \mathrm{p}$.

Scheidegger, A. E., 1953, Examination of the physics of theories of orogenesis: Geol. Soc. America Bull., v. 64, p. 127-150.

Schuchert, Charles, 1935, Historical geology of the AntilleanCaribbean region: New York, John Wiley and Sons, $881 \mathrm{p}$.

Semmes, D. R., 1919, The geology of the San Juan district, Porto Rico: New York Acad. Sci., Scientific Survey of Porto Rico and the Virgin Islands, v. 1, pt. 1, p. 33-110. 
Smith, R. J., and Hildebrand, F. A., 1953, Occurrence of alunite and pyrophyllite in Puerto Rico [abs.]: Geol. Soc. America Bull., v. 64, p. 1476.

Terzaghi, Karl, and Peck, R. B., 1948, Soil mechanics in engineering practice: New York, John Wiley and Sons, $565 \mathrm{p}$.

Thorp, James, and Smith, L. R., 1933, Concerning the origin of the white quartz sands of northern Puerto Rico: Puerto Rico Dept. Agriculture Jour., v. 17, no. 2, p. 157170.

Turner, F. J., and Verhoogen, Jean, 1951, Igneous and metamorphic petrology: New York, McGraw-Hill Book Co., $602 \mathrm{p}$.

Twenhofel, W. H., 1937, Terminology of the fine-grained mechanical sediments: Natl. Research Council Ann. Rept. 1936-37, App. 1, Rept. Comm. Sedimentation, p. 81-104.
[U.S.] Beach Erosion Board, 1948, Punta Las Marias, San Juan, Puerto Rico, Beach Erosion Control Study: U. S. 80th Cong., House Doc. 769, 16 p.

Vening Meinesz, F. A., 1954, Indonesian Archipelago-A geophysical study: Geol. Soc. America Bull., v. 65, p. 143164.

Woodring, W. P., Brown, J. S., and Burbank, W. S., 1924, Geology of the Republic of Haiti: Port-au-Prince, Haiti Dept. Public Works, $631 \mathrm{p}$.

Woodring, W. P., and Thompson, T. F., 1949, Tertiary formations of Panama Canal Zone and adjoining parts of Panåma: Am. Assoc. Petroleum Geologists Bull., v. 33, p. 223-247.

Zapp, A. D., Bergquist, H. R., and Thomas, C. R., 1948, Tertiary geology of the coastal plains of Puerto Rico: U. S. Geol. Survey Oil and Gas Inv. Prelim. Map 85. 


\section{INDEX}

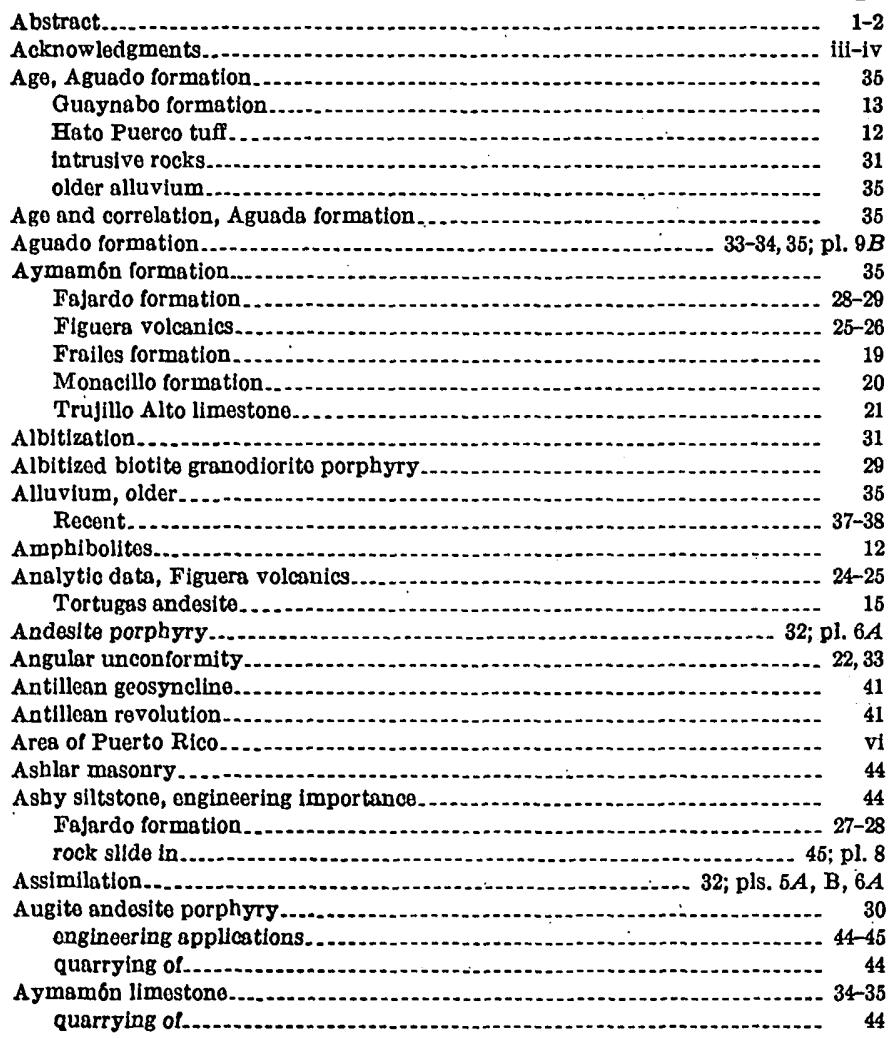

Banded rhyolite vitrophyre, Frailes formstion

Botholith of southesstern Puerto Rico.

Batholithic intrusion

Bay mud.

as foundation

Beach erosion.

Beaches.....

Beach ridges

Beach sand.

$$
\text { restricted use for concrete aggregate }
$$

Beachrock

Berkoy, O. P., quoted

Blotito granodio

Borrow and quarrying

Brick and tile, manufacture of

"Oaguas volcanic island"

Oaneja, Montes de, Aymsmón limestone haystock quarrying.

Carbonlzed plant remains, Gusynabo formation

Cenozoic deposition.

Climate, Puerto Rico

Chemical analyses, Tortugas andesito

Figuera volcanics

granodiorite, Aguado area

OIPW norms, Figuera volcanics

Tortugas andesite
Page
$1-2$
iii-iv

iii-iv

13

12

35
35

$9 B$

35 Diabr

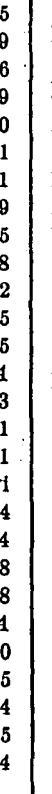

44.
$-30$

Page

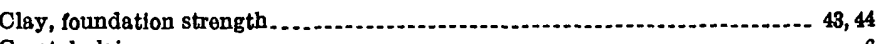

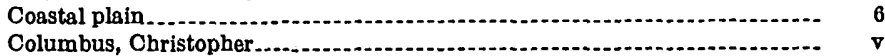

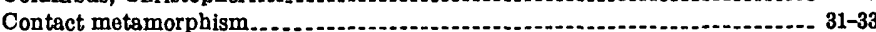

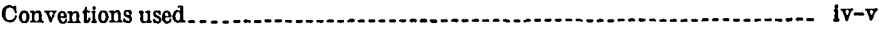

Corozal, correlation of limestone with Figuers volcanics......................... 26

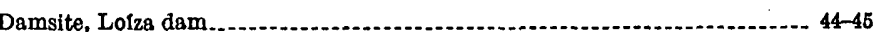

Depositional history, older complex........

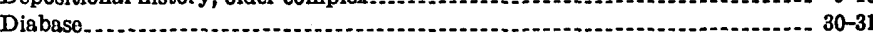

Discussion, Figuera volcanles................. 26-27

Frailes formation......................................................... 17-18

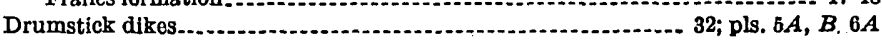

East-west structural alinement.................................................. 42

Eocene (?) rocks...........

Eolianite

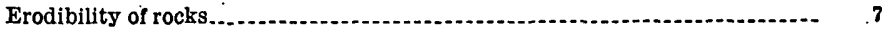

Fajardo formation................................................. 27-29; pls. 7B, 8

rock slide in

rock slide in .............

Frope stability .

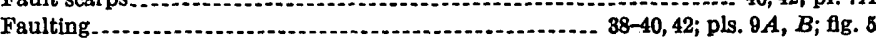

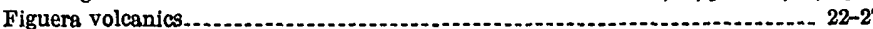

analyses.............................................................. 25

Fill

Flow rock in Hato Puerco tuff..... 12

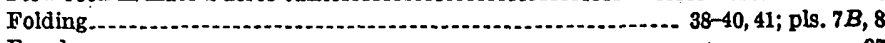

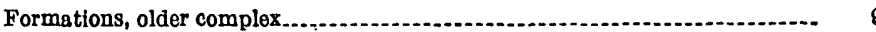

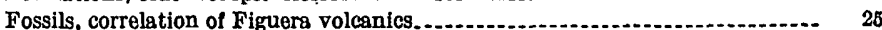

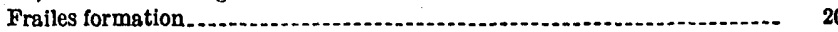

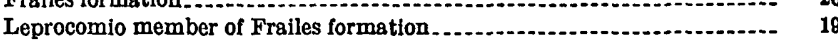

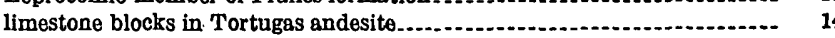

Trujillo Alto limestone

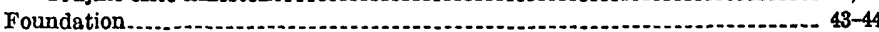

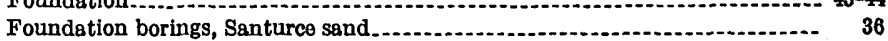

Frailes formation.

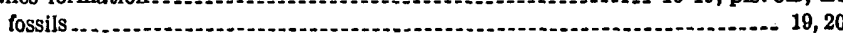

General geology, San Juan area.

Geographic situstion. Puerto Rico

Geologic history of San Juan area, summary.................................... 40-43

Geologic map, San Juan area ...................................................... pl. 2

Geologic mapping, San Juan area......... 3

Geophysical exploration, Palo Seco

Geosyncline, Antillean . .

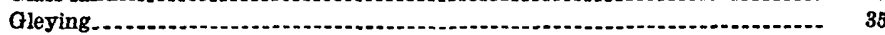

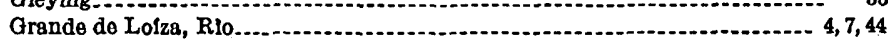

Granodiorite, analyses.

Gravel source, San Juan area...................................................

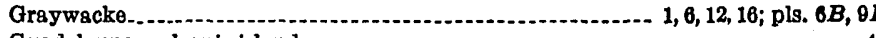

Guadeloupe, volcanic island $\ldots \ldots \ldots \ldots \ldots$
Gus ynobo fault

Guaynabo fault

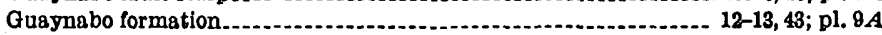

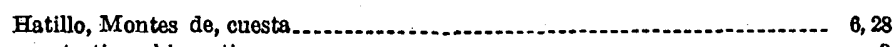

stratigraphic section......................................................... 8

Hato Puerco tuff

dam foundation. ............

quarrying of

Haystack hills, Aymam6n formation.................................................. 34 
Hornblende andesite, analyses................ Page

Hydrologic factors in engineering structure

Introduction.

Intrusive igneous rocks

Island arc.

Karst topography, Puerto Rico

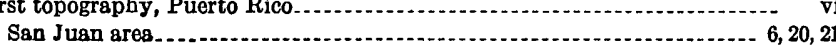

Lagoons.

La Muda fault zone

La Muda limestone member of Frailes formation engineering applications.

quarrying of.

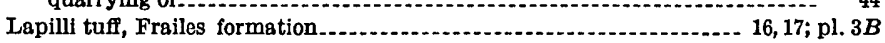

Late Tertiary and Quaternary deposits.......................................... 35-37

Leprocomio limestone member of Frailes formation ........................... 16, 19

fossils.....

quarrying of.

Littoral deposits, Pleistocene.

Recent.

(1)

geographic setting, Puerto Rico

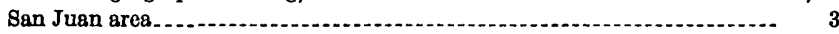

Loiza, correlation of limestone with Figuera volcanics........................

Loiza dam

Luquillo, Sierra de. . . ..............

Marine and eolian deposits, Puerto Rico

iv, vii

Marine deposits, Figuers volcanics.

Metamorphism, contact...... 31, 32-33; pl. $6 B$ regional....

31

Metamorphism and albitization

Metasomatism

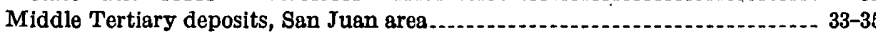

Middle Tertiary rocks, Puerto Rico................................................ vi structure.

Modes, Figuera volcanics

Tortugas andesite

Monacillo formation

New York Academy of Sciences

Northwest structural alinement.

Offishore rocks.

Older complex, Puerto Rico

San Juan area

San Juan area,

San Juan area, structure

Older complex of early reports.............

verthrust

Paleocene (?) rocks.

Petrographic description, albitized biotite granodiorite porphyry augite andesite porphyry.

diabase.

Figuera volcanics

Frailes formation

Hato Puerco tuff.

metamorphic changes

Tortugas andesite

Physical features

Population, San Juan area

Portland cement, San Juan area

"Coastal Geology of Puerto Rico"

revious work

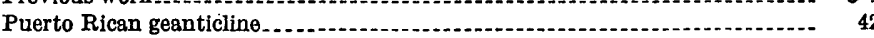

Puerto Rican trough

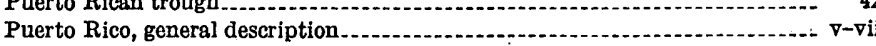

Puerto Rico and neighboring islands, topographic map........................... pl. 1

Punta, Cerro de
Quartz sand ............... Page

Quaternary rocks.................. 35-37

Reef rock-

References cited.

Reticulated mottling............... 35

Road metal, quarrying for

Roads, Puerto Rico......... vi

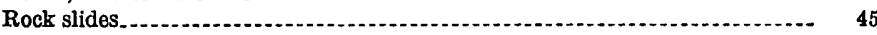

Sand aprons

Sand piles, as drains in foundation...-

San Juan, Bahla de................. 5-6

Isla

San Juan area, geologic map.........

San Patriclo, Montes de, haystack hills................................... 6, 34

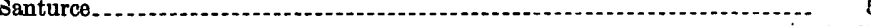

Santurce sand......

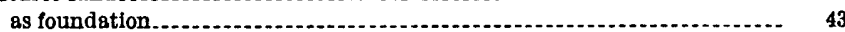

"Sclentife Survey of Porto Rico and the Virgin Islands"

Scope of report.

Sea-level changes.................................................................... 42

Sedimentary rock, blocks in Tortugas andesite............................... 14

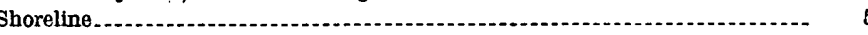

Spllitic pillow lava, petrographic description

Stratigraphic nomenclature of older complex, San Juan area ....................

Stratigraphic relation, Figuera volcanics.

Monaclllo formation......... 20

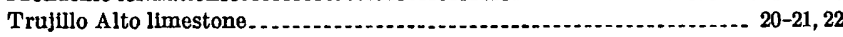

Stratigraphic section, Aguada formation........... 33-34

28

Stratigraphic summary, San Juan area......................................

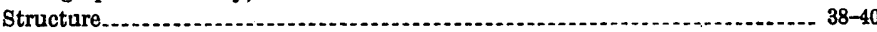

Summary, main geologic events........

Tepee-shaped hills, Aymamón limestone-........................................ 34

Tertiary faunas in older complex.............................................. 12

Tertiary limestone, karst topography

Tertiary orogenies

Tertiary rocks, middle

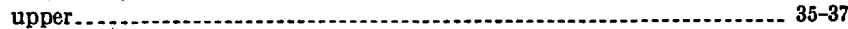

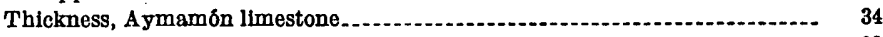

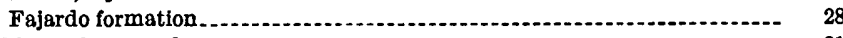

Todd, Ruth, quoted

Topographic maps of Puerto Rico...................................................

Topography of Puerto Rico

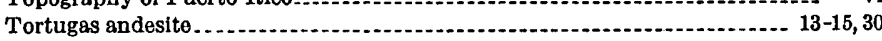
fossils in limestone blocks........

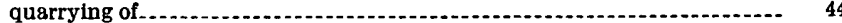

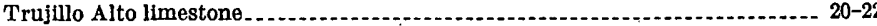
engineering applications. ...................................................... 43 fossils quarrying of

Unconformity, angular . . .

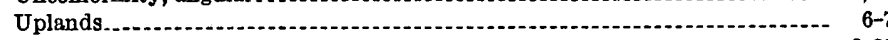

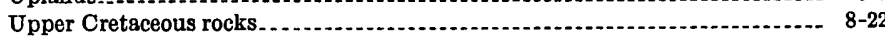

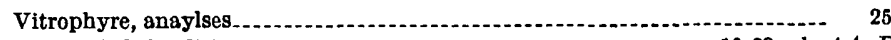
banded rhyolitic............................ 16, 23; pls. $4 A, B$

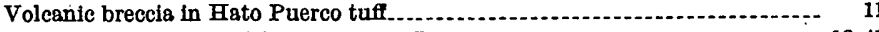

Volcanic cone origin of Hato Puerco tuff....................................... 12, 41

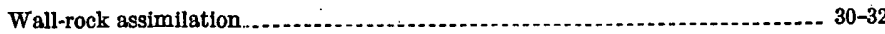

Water-supply project, Loíza dam.................... 44-45

Water-well $\log$, Rum Pilot Plant .................................................. 38

Weathering, Leprocomio limestone member.............. 19

Welded tuff, Figuera volcanics............................................... 24, 26

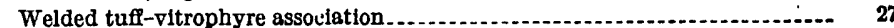

